\title{
STAGgERED BOARDS AND FiRM VALUE, REVISITED
}

\author{
K. J. Martijn Cremers ${ }^{*}$, Lubomir P. Litov ${ }^{* *}$, Simone M. Sepe ${ }^{* * *}$
}

December 5, 2013

\begin{abstract}
This paper revisits the association between firm value (as proxied by Tobin's Q) and whether the firm has a staggered board. As is well known, in the cross-section firms with a staggered board tend to have a lower value. Using a comprehensive sample for 1978 - 2011, we show an opposite result in the time series: firms that adopt a staggered board increase in firm value, while de-staggering is associated with a decrease in firm value. We further show that the decision to adopt a staggered board seems endogenous, and related to an $e x$ ante lower firm value, which helps reconciling the existing cross-sectional results to our novel time series results. To explain our new results, we explore potential incentive problems in the shareholder-manager relationship. Short-term oriented shareholders may generate myopic incentives for the firm to underinvest in risky long-term projects. In this case, a staggered board may helpfully insulate the board from opportunistic shareholder pressure. Consistent with this, we find that the adoption of a staggered board has a stronger positive association with firm value for firms where such incentive problems are likely more severe: firms with more R\&D, more intangible assets, more innovative and larger and thus likely more complex firms.
\end{abstract}

\footnotetext{
* Mendoza College of Business, University of Notre Dame. Email address: mcremers@,nd.edu

** The University of Arizona, Eller School of Management; and Wharton Financial Institutions Center, University of Pennsylvania. Email address: 1 itov@email.arizona.edu

*** James E. Rogers College of Law, University of Arizona; and Institute for Advanced Study in Toulouse - Fondation Jean-Jacques Laffont - Toulouse School of Economics. Email address: simone.sepe@law.arizona.edu
} 


\section{Introduction}

Discussions on the relationship between boards of directors and shareholders have occupied the center stage of the corporate governance debate for years, showing no sign of waning. On the one hand, advocates of shareholder empowerment argue that a shareholder-driven corporate model would produce valueincreasing governance arrangements by reducing the room for managerial opportunism (Bebchuk, 2005, 2007, 2013). On the other, opponents of this model contend that "director primacy" is preferable (Bainbridge, 2006; Blair and Stout, 1999), as shareholder dominance would produce its own, significant set of agency costs (Bratton and Wachter, 2010). In particular, shareholder dominance could lead to managerial "short-termism": under the pressure of empowered shareholders, managers would have incentives to pursue short-term returns at the expense of long-term firm value (Lipton and Rosenblum, 1991; Strine, 2006).

Staggered (or classified) boards have long played a central role in this debate. In a staggered board, directors are typically grouped into three different classes. Only one class of directors stands for election each year, with each director being elected to a term of typically three years (i.e., a term equal in length to the number of classes). In contrast, in a non-staggered board, all directors stand for election every year, as they serve one-year terms. Hence, a staggered board's directors are further removed from short-term shareholder pressure, because challengers need to win at least two election cycles to gain board majority when only about a third of directors stands for (re-)election each year. It is thus unsurprising that advocates of shareholder empowerment view staggered boards as a quintessential corporate governance failure. In this view, insulating directors from market discipline diminishes director accountability and encourages self-serving behaviors by incumbents such as shirking, empire building, and private benefits extraction (Bebchuk and Cohen, 2005; Bebchuk, Cohen, and Ferrell, 2009). On the contrary, defendants of staggered boards view staggered boards as an instrument to preserve board stability and strengthen long-term commitments to value creation (Koppes, Ganske, and Haag, 1999; Lipton, Mirvis, Neff, and Katz, 2012). 
This debate notwithstanding, the existing empirical literature supports the claim that board classification seems undesirable. With almost no exception, ${ }^{1}$ extant empirical studies find that, in the cross-section, staggered boards are associated with lower firm value as measured by Tobin's Q (Bebchuk and Cohen, 2005; Bebchuk, Cohen, and Ferrell, 2009; Faleye, 2007) and negative abnormal returns (Mahoney and Mahoney, 1993; Bebchuk, Coates, and Subramanian, 2002; Masulis, Wang, and Xie, 2007) at economically and statistically significant levels. The leading shareholder voting advisory firm, ISS, is likewise unambiguous in its support for board declassification and advocacy against adopting a staggered (or classified) board (ISS, 2013).

This paper calls into question the interpretation of the evidence in this literature (i.e., as supporting the managerial entrenchment view of staggered boards), as we document that the negative cross-sectional association between staggered boards and firm value is reversed in the time series. ${ }^{2}$ We first replicate the existing evidence that cross-sectionally, firms with staggered boards tend to have lower firm values as measured by Tobin's Q. After that, our main new finding is that in the time series, staggering up is associated with an increase in firm value and de-staggering is associated with a decrease in firm value. Our striking time series result casts a doubt on the direction of causation between firm value and staggered boards as interpreted in the empirical literature to date. In particular, our results suggest that causation might go from low firm value to the decision to adopt a staggered board rather than in the opposite direction.

Causality concerns are of course not new. These concerns emerge because governance arrangements generally do not arise exogenously, but are chosen endogenously in response to firm-specific circumstances (Adams, Hermalin, and Weisbach, 2010). This complicates the interpretation of the identified cross-sectional negative correlation between staggered boards and firm value, since staggering decisions could be partly motivated by—rather than the cause of-low firm values. Despite broad acknowledgement of this problem in prior studies, these studies are more limited in how they address endogeneity, as they exclusively employ

\footnotetext{
${ }^{1}$ The sole empirical exception we could find is given by the study of Bates, Becher, and Lemmon (2008), which finds that, among others, target shareholder returns are not influenced by the presence of a staggered board. However, this study falls short of endorsing a favorable view of staggered boards, more limitedly suggesting that "a circumspect policy approach be applied when considering the adoption or dissolution of [staggering provisions]."

2 Our results employ a longer and more comprehensive database - from 1978 to 2011, covering 3,023 firms - tracking more staggering and de-staggering decisions than the existing literature, including hand-collected data for 1978 - 1989 from Cremers and Ferrell (2013). As a comparison, Bebchuk and Cohen (2005), Faleye (2007) and Bebchuk, Cohen, and Ferrell (2009) use data for 1995 - 2002 for a sample covering between 1,400 and 1,800 firms each year.
} 
cross-sectional regressions to estimate the relation between staggering decisions and firm value. The focus on a cross-sectional association is largely attributable to limitations in available staggered board data and the difficulty of performing a time series analysis of this relation using limited data.

As a result, an essential contribution of this paper is our use of a more comprehensive database (i.e., from 1978 to 2011), which allows us to consider the time series evidence as well. ${ }^{3}$ This is particularly important because during the 1995 - 2002 time period used in much of the recent literature (e.g., Bebchuk and Cohen (2005), Faleye (2007), and Bebchuk, Cohen, and Ferrell (2009)), there are very few instances of firms adopting a staggered board or de-staggering. However, we document that a significant proportion of firms staggered up during the 1978 - 1989 period (see also Cremers and Ferrell (2013)), and a likewise considerable proportion of firms de-staggered during the 2005 - 2011 period.

Our main time series result, that firm value goes up if the board changes from a single class of directors to a staggered board (and the reverse for de-staggering), is robust and both economically and statistically significant. Using pooled panel Tobin's Q regressions with firm fixed effects and the full 1978 - 2011 time period, we find that staggering up (down) is associated with a permanent increase (decrease) in Tobin's Q of 6.3\%. We likewise document a positive association between changes in Tobin's $\mathrm{Q}$ and changes in whether the firm has a staggered board, consistent with our firm fixed effects results. Economically, we find that staggering up (down) this year is associated with an increase (decrease) in Tobin's Q of 3\% over the next fiscal year, of $7.9 \%$ over the next two years and a cumulative increase of $15.3 \%$ over the next five fiscal years.

\footnotetext{
${ }^{3}$ Our data combines three different sets of staggered board data: (i) data from the Cremer-Ferrell (2013) hand-collected database for the 1978-1989 time period; (ii) a combination of data compiled by the Investor Responsibility Research Center (IRRC) and hand-collected data for the 1990-2006 time period. Indeed, the IRRC now publishes yearly volumes providing data on several corporate governance provisions, including staggered boards. Over the period 1990-2006, however, the IRRC did not publish its volumes each year. Hence, we hand-collected information on staggered boards for each missing year in the IRRC volumes (i.e., 1991, 1992, 1994, 1996, 1997, 1999, 2001, 2003, and 2005). As the source for our hand-checked data, we used the SEC website database, which collects information included in the SEC $10-\mathrm{K}$ and DEF 14-A forms. These forms provide information on, among other issues, a company's history and organizational structure, voting procedures, company performance, and board features, from which we are able to obtain data on both staggering and de-staggering decisions; (iii) a combination of data from the IRRC database and handcollected data for the 2007-2011 time period (using data from the SharkRepellent.net). Although IRRC volumes for the period 2007-2011 were annually updated, we hand-checked data for the period 2009-2011 because we found some minor miscoding of the staggered board data.
} 
We confirm that board staggering up (down) is associated with an increase (decrease) in financial value by constructing portfolios of firms around the time the firm staggers up (down). For example, say a firm does not have a staggered board at the end of fiscal year 2000 but has one in place at the end of fiscal year 2001. This implies that the staggered board has been approved sometime over the "staggering transition year," i.e., in case of this example, the 12-month period from the end of fiscal year 2000 to the end of fiscal year 2001. We then construct a portfolio that at any point in time includes only those stocks of firms during such transition years. The portfolio of firms in "staggering transition years" has a positive abnormal return, while the portfolio of firms in analogously determined "de-staggering transition years" has a negative abnormal return. The long-short portfolio has an annualized 4-factor alpha of about 16\% (with a t-statistic of 2.24) if equally-weighted and about $18 \%$ (with a t-statistic of 2.35 ) if value-weighted.

A natural explanation for the sign change between the cross-sectional and time series results may be that the cross-sectional results are largely due to reverse causality. In particular, if having a relatively low firm value induces some firms to adopt a staggered board (rather than a staggered board causing a lower firm value), this could explain the cross-sectional result that firms with staggered boards tend to have low firm values. However, reverse causality could not explain the time series results, as firm value tends to go up after the adoption of a staggered board.

Consistent with the hypothesis of reverse causality, we find that low firm value is a significant predictor of board staggering. We consider two non-linear specifications for the decision to adopt a staggered board: a random effects probit model and the Cox proportional hazard model. These suggest that a standard deviation decrease in firm value can explain 30\% (probit model) to 58\% (Cox model) of board staggering events. Conversely, we find no statistically significant association between firm value and the decision to de-stagger.

If reverse causality can explain the negative association between firm value and staggered boards, then we would expect this negative association to become considerably weaker once we control for lagged firm value. The empirical results strongly support this conjecture. For our main cross-sectional results using pooled panel Tobin's Q regressions with industry (but no firm) fixed effects over our full 1978 - 2011 period, we find a coefficient on the staggered board dummy of -0.041 that is strongly statistically significant (t-statistic 
of 2.43). Adding lagged $\mathrm{Q}$ as a control for reverse causality to this specification, we find a coefficient on the staggered board dummy that is much reduced at -0.008 and statistically insignificant (t-statistic of 1.60).

These results challenge the managerial entrenchment view of staggered boards. They also raise the question of how one could interpret the positive association between firm value and the decision to adopt a staggered board. While we cannot demonstrate any causal link, we explore an explanation based on potential incentive problems in the shareholder-manager relationship. The managerial entrenchment view maintains that an increased threat of managerial removal by the shareholders produces desirable disciplinary effects and thus improves firm value. The central assumption here is that firm value provides a reliable and informative signal about managerial performance, where low firm value efficiently triggers shareholder interference. However, in contexts of high asymmetric information or very noisy market prices, such signals may be distorted, which may engender sorting or signaling problems (Shleifer and Vishny, 1990).

Applied to publicly traded corporations, this means that in some cases a relatively low firm value may be attributable to the difficulty of firm insiders to share information about the firm's prospects (rather than poor managerial performance). One example is the case where considerable firm-specific capital expenditures are required in order to enhance long-term firm value. Such large capital expenditures will decrease short-term earnings, and may lower firm value, in the near term if shareholders are less convinced about their need and/or may ascribe them to empire building tendencies. Alternatively, shareholders may lack the incentives or the ability to expend the resources required to address such information problems, especially in large, complex firms where sorting costs may increase exponentially (Tirole, 2006). Eberhart, Maxwell, and Siddique (2004) provide evidence that is consistent with this. They show that, while significant increases in $R \& D$ investments are beneficial for the firm in the long run on average, the stock market tends to underreact to their announcement, leading to positive abnormal stock returns for such firms on average over the next 12 months. These results suggest that some shareholders may initially not recognize the benefits of R\&D investments, as they usually have a long-term nature.

Asymmetric information and long-term investments are central to many if not most modern large firms, whose competitive success is increasingly dependent on complex and intangible investments (Porter, 1992; 
Zingales, 2000). Hence, if long-term investments lead to a short-term decrease in firm valuations, then an increased threat of managerial removal may produce myopic incentives (DeAngelo and Rice, 1983; Laffont and Tirole, 1988; Stein, 1988, 1989). That is, anticipating that low firm value may trigger shareholder retribution, managers may be induced to underinvest in future profitability or "posture", i.e., increase shortterm payoffs at the expense of long-term value (Bushee, 1998; Graham, Harvey, and Rajgopal, 2005; Tirole, 2006).

The problem of myopic incentives and the difficulty of committing to long-term firm-specific investments suggest a positive account of staggered boards that can potentially explain our main empirical result. Specifically, directors who do not have to stand for election every year may be less susceptible to making myopic decisions and have longer-term incentives relative to directors who are up for re-election annually. Staggered boards may thus have a positive association with firm value if such boards have an enhanced ability to resist myopic incentives and pursue long-term and/or specific investments.

We test this positive account of staggered boards by considering whether the positive association between adopting a staggered board and firm value is stronger for firms with more long-term and firmspecific investments, more complexity, and stronger executive compensation incentives to take on more risk (and vice versa for de-staggering). Our empirical results strongly support such positive account. For example, the positive association between the adoption of a staggered board and firm value is significantly stronger among firms with higher R\&D expenses as a fraction of their revenue, among firms with more intangible assets, among firms that are more successful in innovation (as measured by their patent citation counts) and among firms with larger size (with firm size used as a proxy for complexity as in Faleye, 2007 and Core, Holthausen, and Larcker, 1999). ${ }^{4}$

An alternative explanation for the positive association between staggering up and firm value is that firms that stagger up may simultaneously decrease other entrenching governance mechanisms. Similarly, the decision to adopt a staggered board may be primarily taken by firms whose other corporate governance

\footnotetext{
${ }^{4}$ While Faleye (2007) uses total assets as measure of firm size, we follow Core, Holthausen, and Larcker (1999) and measure the logarithm of a firm's sales as measure of firm size.
} 
mechanisms provide strong (and maybe strengthening) safeguards against managerial entrenchment. Using proxies such as forced CEO turnover, CEO - board chairman duality, and the G-Index of shareholder rights, we find no support for this alternative explanation. In particular, if we interact the presence of a staggered board with $\mathrm{CEO}$ - board chairman duality, we find that upon adopting a staggered board, firm value tends to increase more if the CEO also chairs the board. Our results suggest that having an empowered CEO only positively associates with firm value if complemented with a staggered board. If we interpret staggered boards as having more power vis-à-vis the shareholders, then we can conclude that more powerful boards and CEOs seem complements.

Finally, we consider whether the positive association between the adoption of a staggered board and firm value is related to strong equity-based incentives that guard against managerial entrenchment. We find no significant interaction for 'CEO Delta' (i.e., the sensitivity of CEO compensation to stock price). However, the interaction between adopting a staggered board and 'CEO Vega' (reflecting the sensitivity of CEO compensation to stock return volatility) is strongly positively related to firm value, suggesting that staggered boards are better suited to oversee compensation policies that induce effective managerial risk-taking. This may be because with a staggered board, both CEOs and boards may be less fearful of immediate shareholder retribution upon potentially bad short-term realizations of risky investment projects and can therefore afford to implement less conservative executive compensation incentives.

Our interest in executive incentives is also motivated by the view that sees high executive compensation itself as major evidence of managerial entrenchment. Under this view, entrenched managers would be able to use their positional advantage to obtain returns well above the information rents needed to preserve an agent's incentives (Bebchuk and Fried, 2004). Specifically, Faleye (2007) argues that one of the channels through which staggered boards promote entrenchment is a significant reduction in the effectiveness of executive incentives. Our evidence is not consistent with this. Rather, when we add the interaction of the adoption of a staggered board with the total level of CEO compensation to firm value regressions, this interaction has a strongly positive interaction. This suggests that staggered boards are more valuable at firms with a high paid CEO, potentially because these CEOs are particularly talented at the challenging task of 
running complex, large organizations with a longer-term outlook - the same firms where staggered boards are more strongly positively associated with firm value.

The remainder of the paper is organized as follows. In Section 2, we review the related empirical literature. In Section 3, we present our sample and summary statistics. In Section 4, we discuss the results of our valuation analysis of staggered boards as well as the results of our interaction analysis. In Section 5, we provide robustness analysis. We conclude in Section 6.

\section{Related Literature}

Our paper contributes to several strands of literature. In the first place, we contribute to the literature on staggered boards and firm value. Prior studies find that, in the cross-section, having a staggered board is associated to a reduction in firm value (Bebchuk, Coates, and Subramanian, 2002; Bebchuk and Cohen, 2005; Faleye, 2007; Masulis, Wang, and Xie, 2007; Cohen and Wang, 2013). We add to these studies in two important ways.

First, we employ a longer and more comprehensive database (i.e., covering the time period 1978-2011). This period includes two sub-periods with substantial instances of firms either adopting a staggered board (in 1978 - 1989) or de-staggering (in 2005 - 2011), which allows us to consider time-series evidence in addition to cross-sectional evidence. Second, we show that the negative cross-sectional association between staggered boards and firm value is reversed in the time series. This result suggests that board insulation through staggered elections is associated with increases, rather than decreases, of firm value over time. This is consistent with the findings of Larcker, Ormazabal, and Taylor (2011), who document a negative market reaction to recent legislative and regulatory actions designed to increase shareholder power, including a proposal to eliminate staggered boards. ${ }^{5}$

Relatedly, we also contribute to the extensive literature that investigates the relationship between market discipline, governance arrangements, and firm value. Following seminal prior studies by Manne (1965) and Jensen (1988; 1993), Gompers, Ishii, and Metrick (2003) find a negative cross-sectional correlation between

5 This proposal was included in the 2009 Shareholder Bill of Rights Act by Senator Charles Schumer as one of several measures designed to provide shareholders with enhanced corporate power. 
firm value and increased board insulation from market discipline as measured by a broad shareholder rights index (the "G-Index"). These results suggest that board-insulating governance arrangements in general promote inefficient managerial-entrenchment. Subsequent studies support this hypothesis, finding that the negative correlation between board-insulation and firm value holds for different subsets of G-Index provisions (Bebchuk, Cohen, and Ferrell, 2009; Cremers and Nair, 2005; Masulis, Wang, and Xie (2007)) ${ }^{6}$ as well as for longer computation periods and in the time series (Cremers and Ferrell, 2013).

Along the same line of inquiry, Bebchuk and Cohen (2005) and Faleye (2007) document that the presence of a staggered board is a primary driver of the identified negative correlation between board insulation and lower firm value. Event studies also support the entrenchment view of board-insulating arrangements, both relative to their adoption (or amendments) (for a survey see Bhagat and Romano, 2002a; 2002b) and related regulatory and case law changes (Karpoff and Malatesta, 1989; Cohen and Wang, 2013; Cremers and Ferrell, 2013).

We supplement this body of work in two ways. First, we document that using pooled panel Tobin's Q regressions with firm fixed effects and over our full 1978-2011 time period, the interaction term between staggered boards and the other provisions in the G-Index is insignificant. Second, we show that a portfolio strategy that buys firms around the time they adopt a staggered board and sold firms around the time they destagger would have earned an annual alpha of about $16 \%$. Overall, our results challenge the entrenchment view of staggered boards.

Next, we contribute to the literature examining the value relevance of a firm's R\&D and intangible investments. Prior studies in this strand of literature highlight two main findings. On the one hand, they report that investments in $\mathrm{R} \& \mathrm{D}$ and intangibles tend to be associated with increased productivity as well as higher firm value in the long term (Hirschey, 1982; Chan, Martin, and Kensinger, 1990; Chauvin and Hirschey, 1993; Lev and Sougiannis, 1996; Eberhart, Maxwell, and Siddique, 2004). On the other, they find

${ }^{6}$ The G-Index includes 24 governance provisions. Aiming at disentangling the most important of these provisions relative to the negative impact on firm value, Bebchuk, Cohen, and Ferrell (2009) introduce an entrenchment index (the "E-Index") based on six of the G-Index provisions (still including staggered boards). Cremers and Nair (2005) use an even more restricted governance index, which is based on four of the G-Index provisions. Masulis, Wang, and Xie examine still different subsets of the G-Index. However, regardless of the specific subset they employ, all these studies find confirmation of the negative relation between board-insulating measures and firm value. 
that the long-term benefits of such investments are regularly underestimated in the short-term, suggesting the existence of severe information asymmetry problems. For example, Chan, Lakonishok, and Sougiannis (2001) report that firm with high $R \& D$ to equity market value (which tend to have poor past returns) earn large excess returns. Similarly, Eberhart, Maxwell, and Siddique (2004) find that investors tend to underreact to the announcement of increases in R\&D expenditures, suggesting that they underestimate the potential cash flow of such investments. Further, Bushee (1998) argues that short-term institutional investors create incentives for corporate managers to reduce investment in $\mathrm{R} \& \mathrm{D}$ in order to meet short-term earnings goals. We supplement this literature by showing that the positive impact of staggered boards on firm value is stronger in firms with larger $\mathrm{R} \& \mathrm{D}$ expenditures and a higher fraction of intangible assets to total assets, suggesting that board insulation from short-term shareholder interference is especially valuable in contexts where asymmetric information problems are more acute.

Further, our work relates to the literature examining how structural differences across boards affect the way in which firms function and how they perform (for a review see Adams, Hermalin, and Weisbach, 2010). In particular, we contribute to two strands of research within this literature: the first examines how board structure affects the incidence and performance sensitivity of forced CEO turnover, while the second investigates how $\mathrm{CEO}$ - board chairman duality relates to board conduct and firm performance. Concerning the first strand of research, the pioneering study is Weisbach (1988), who finds that forced CEO turnover is more sensitive to firm performance (i.e., with lower firm value predicting higher CEO turnover) in firms with outsider-dominated boards. This suggests that board independence increases the likelihood of effective CEO turnover. More closely related to our research, Faleye (2007) finds that the presence of a staggered board decreases both the incidence and the performance sensitivity of CEO turnover. However, testing the same interaction term in the time series, we find an insignificant, albeit positive, association on firm value, suggesting that the adoption of a staggered board is not likely to lead to less effective CEO turnover.

Concerning the literature on CEO - board chairman duality, several studies test whether such a board feature gives CEOs excessive control over the board to the detriment of shareholders (Jensen, 1993; Bebchuk and Fried, 2004). Consistent with this view, Goyal and Park (2002) find that CEO - board chairman duality 
decreases the sensitivity of CEO turnover to firm performance. Similarly, Adams, Almeida, and Ferreira (2005) report that CEOs who also chair the board are better positioned to influence corporate decisionmaking. Adams, Hermalin, and Weisbach (2010), however, suggest that these results might be endogenous, i.e., that $\mathrm{CEO}$ power is simply a consequence of a demonstrated high ability to manage the firm effectively. This explanation is in line with the work of Brickley, Coles, and Jarrell (1997), who find an insignificant impact of CEO - board duality on firm value, and Dei, Engel and Liu (2011), who show that splitting the $\mathrm{CEO}$ and board chairman roles is associated with a decrease in firm value. Consistent with Dei, Engel, and Liu (2011), we find that having both a staggered board and a CEO who chairs the board leads to an increase in firm value.

Finally, we contribute to the literature on CEO compensation incentives. From a theoretical perspective, the proposition that executives should be paid for performance is well settled and has been formally analyzed through principal-agent models in several studies (Holmstrom, 1979; Shavell, 1979; Grossman and Hart, 1983). From an empirical perspective, however, the existing literature can be divided into two distinct groups, supporting opposite models of the pay setting process.

The first group supports an arm's length bargaining model (premised on an active executive labor market (Cremers and Grinstein, 2013)), under which boards of directors negotiate compensation arrangements with executives in the best interest of their shareholders (Jensen and Murphy, 1990a; 1990b; Himmerberg and Hubbard, 2000; Hubbard, 2005). The second, instead, supports a managerial power model under which entrenched executives control the board and, therefore, are able to set their own compensation arrangements (Bebchuk and Fried, 2004). Under this view, the adoption of board-insulating measures such as staggered elections would play a central role in enabling entrenched executives to raise their pay levels (Bebchuk and Grinstein, 2005; Faleye, 2007). We add to these studies by showing that, on the one hand, the presence of a staggered board does not seem to alter the basic incentive structure of executive pay and, on the other, it might even provide executives with better incentives to take efficient risk.

\section{Data and Descriptive Statistics}




\subsection{Data Sources}

Our data come from several sources, with the overall data sample covering the time period 1978-2011. However, as specified in the ensuing discussion, the availability of the data varies with the different data sources we employ for the various variables used in our analysis.

\subsubsection{Staggered Boards}

We obtain data for the key independent variable of our study, i.e., Staggered Board $[t$, from two main sources, covering a total number of 3,023 firms. For the time period 1990-2011, as in all prior studies on the value impact of staggered boards (Bebchuk and Cohen, 2005; Faleye, 2007; Masulis, Wang, and Xie, 2007), we use the corporate governance dataset maintained by Risk Metrics, which acquired the Investor Responsibility Research Center (IRRC)).

Since 1990, the IRRC has published volumes every $2-3$ years providing detailed information on several governance provisions, including staggered boards, at about 1,500 firms (with the number of firm increasing up to $1,900-2,000$ firms in more recent volumes). Starting from 2007, the IRRC publications have become annual. During the period 1990-2006, however, the IRRC only published volumes in the following years: $1990,1993,1995,1998,2000,2002,2004$, and 2006. To remedy the lack of available data for the years in which the IRRC did not publish its volumes, most prior studies using the IRRC dataset assume that the governance provisions reported as in place in the years of a published volume were in place in the year following that volume's publication (Gompers, Ishii, and Metrick, 2003; Bebchuk and Cohen, 2005; Masulis, Wang, and Xie, 2007; Cremers and Ferrell, 2013). In contrast to these studies, we hand-checked all missing years in the 1994 - 2006 time period using proxy statements from the SEC's EDGAR website. ${ }^{7}$ An advantage of this method of filling in missing years is that we do not assume away changes in staggering-up and de-

\footnotetext{
${ }^{7}$ In particular, the SEC 10-K and DEF 14-A forms provide information on voting procedures and board features, from which we are able to obtain data on both staggering and de-staggering decisions.In addition, we also hand checked the accuracy of the IRRC data for the time period 2007 -2001 by using data from SharkRepellent.net. We did so because, while IRRC volumes were annually update during this period, we found some minor miscoding of the staggered board data in 2009-2011.
} 
staggering decisions that might have taken place between the years with available IRRC data and subsequent years without available IRRC data.

Further, for the time period 1978-1989, we use data from Cremers and Ferrell (2013), who comprehensively hand-collected information on firm-level corporate governance provisions for these years, including information on the same provisions tracked by the IRRC for the period 1990-2011 and, in particular, staggered boards. As argued by Cremers and Ferrell (2013), including pre-1990 data is particularly valuable because the 1980 s were characterized by significant time variation in corporate governance features (including board staggering) as a result of the important changes that took place in those years in takeover activity, the law surrounding the use of anti-takeover defenses, and the strength of shareholder rights.

As a result, the use of a more comprehensive database, i.e., from 1978 to 2011, allows us to track more staggering and de-staggering decisions than the existing literature and, therefore, to document both the crosssectional and time-series dimension of the relationship between staggered boards and firm value.

\subsubsection{Main Dependent Variables}

Since our main focus is on the value relevance of staggered boards, the main dependent variable in our analysis is firm value. Consistent with several prior studies investigating the relation between governance arrangements and firm value (Demsetz and Lehn, 1985; Morck, Shleifer, and Vishny, 1988; Lang and Stultz, 1994; Yermack, 1996; Daines, 2001; and Gompers, Ishii, and Metrick, 2003), we measure firm value using Tobin's Q $\left(Q_{[t]}\right)$. We define Tobin's $\mathrm{Q}$ as the ratio of the market value of assets to the book value of assets (as in Fama and French, 1992) and use Compustat as the relevant data source.

As an additional measure of changes to firm value, we use the stock returns surrounding changes of the staggered board structure, obtaining stock return data for both our equally weighted portfolio analysis and value weighted portfolio analysis from the CRSP database (see Section 4.1.3 below). From the same database, we also obtain data on the number of outstanding shares and share prices, which we employ in our value weight portfolio analysis.

\subsubsection{Other Controls}


In our analysis, we always include the following control variables: Ln (Assets) $)_{t t}$, Delaware Incorporation $[t$, $\mathrm{RO} A_{[t]}, C A P X /$ Assets $_{[t]}$, and R\&D/ Sales $[t]$. Additionally, in a few regressions and in our robustness tests, we also include $G$-Index $[t], L n(G-I n d e x)_{[t]}, L n\left(\right.$ Assets $_{[t}$, Insider Ownership $[t]$, and Insider Ownership ${ }_{[t]}$, to replicate more closely the results in Bebchuk and Cohen (2005). We provide brief definitions of all the controls in Table 1.

Among the variables appearing in our extended set of controls, the G-Index $[t$, introduced by Gompers, Ishii, and Metrick (2003), is a composite of twenty-four pro-management governance features-including staggered boards - which measures the strength of shareholders rights by adding one point if any of the provisions included in the index is present. Higher scores on the G-Index $[t]$ indicate the presence of a larger number of pro-management provisions and, therefore, weaker shareholder rights.

In computing the G-Index $[t$, we replicate Bebchuk and Cohen (2005) to isolate Staggered Board $[t]$ from the other index provisions. As concerns G-Index $[t]$ data, we obtain data from the Cremers-Ferrell dataset for the period 1978-1989 and the Risk Metrics (formerly IRRC) dataset for the period 1990-2011. Because, as noted above, IRRC volumes are only available for certain years during the time period 1990-2006, for all provisions other than Staggered Board $[t]$ we assume that any change took place in the year when it was first reported. Further, because after 2006 the IRRC volumes do not provide data on all the governance features included in the $G$-Index $[t$, we assume that values for the $G$-Index $[t]$ provisions that are missing during the period 2007 2011 are the same as the values reported in 2006.

Concerning the variables appearing in our extended test of controls, we compute Insider Ownership $[t]$ as follows. For the time period 1986-2006, we use annual data from Compact Disclosure, which provides monthly updated financial information on the SEC filings of U.S. publicly traded companies with assets in excess of $\$ 5$ million. Specifically, we use the data item SO, reporting data on the combined equity holdings of a firm's officers and directors, whom we refer to as insiders (as standard in the literature). Because the change in the information content between two consecutive CD-ROMs in Compact Disclosure is fairly small and we do not have access to all the CDs, we use the October CDs to produce our data set for the period 1986-2006. The disadvantage of using Compact Disclosure for our study is that it primarily covers NYSE and AMEX 
firms before 1995. Accordingly, we mainly use Insider Ownership $[t]$ in robustness tests, as this control substantially reduces our sample size.

Finally, we use Compustat as our primary data source for the several control variables reflecting the financials of the firm that we use throughout our analysis (e.g., $R O A_{[t]}, C A P X / A s s e t s_{[t}$, and R\&D/Sales $\left[{ }_{[t]}\right)$.

\subsubsection{Interacted Variables}

To supplement our firm value analysis, we also study the interacted impact on firm value of staggered boards and a series of variables of interests, including investment policy and operational complexity variables, board features and governance provisions variables, and executive compensation variables.

\section{i. Investment Policy and Operational Complexity Variables}

In order to consider whether, and how, the relation between staggered boards and firm value changes depending on a firm's investment policy and level of complexity, we employ the following variables: R\&D/

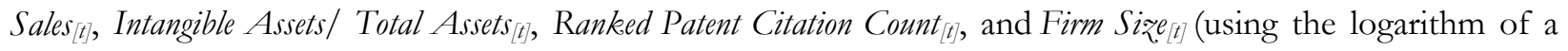
firm's sales as proxy for complexity as in Core, Holthausen, and Larcker, 1999). For most of these variables, we are able to obtain data for the full time period we consider from the Compustat database (the annual update file). The exception is Ranked Patent Citation Count $[t]$, which we derive from the NBER U.S. Patents Citation File for 1978 - 2003.

\section{ii. $\quad$ Board Features and Governance Provisions V ariables}

We consider whether, and how, the relation between staggered boards and firm value changes depending on specific board features and/or governance provisions, using the following variables: CEO Turnover ${ }_{[t}$, CEOBoard Chairman Duality $[t$, and G-Index $[t]$.

As concerns $C E O$ Turnover $_{t t}$, which we define as a binary variable equal to one if the CEO was forced to leave office in a given fiscal year and zero otherwise, we obtain data from Jenter and Kanaan (2010). As their dataset covers 1991 to 2003, we only compute CEO Tumover $[t]$ for that time period. For CEO-Board Chairman Duality $_{[t}$, we use data for 1996 - 2011 from the BoardEx database and the Risk Metrics (formerly IRRC) database, both of which provide information on a director's characteristics. 


\section{iii. Executive Compensation Variables.}

We consider whether, and how, the relation between staggered boards and firm value changes depending on executive compensation incentives, by employing the following variables: CEO Delta $[t]$, CEO Vega $a_{t]}$, and CEO Total Compensation $[t$, which we derive from the ExecuComp database. For CEO Delta $[t]$ and CEO Vega $[t]$ (which we calculate following the methodology implemented by Core and Guay (2002), as standard in the literature), the ExecuComp database covers the time period 1992 - 2010. For CEO Total Compensation $[t]$, instead, the ExecuComp database provides data from 1992 to 2011.

Again, as in our other interaction analyses, we observe that the inclusion of executive compensation interaction terms - and, in particular CEO Vega $a_{[t]}$ and CEO Delta $a_{[t]}$-substantially reduces our overall sample size.

\subsection{Summary Statistics}

Table 2 presents descriptive statistics of all the variables we use. In the overall cross-section nearly 53\% of all firms have a staggered board. The average $Q_{[t]}$ in our sample is 1.581 with a standard deviation of 0.867 . In results that are not tabulated, we compare the averages of the control variables across the sample of firms with and without staggered boards. Overall, we find no substantial differences across the two samples.

\subsection{Staggering and De-staggering}

Figure 1 presents the percentage of firms with a staggered board in our sample each year from 1978 to 2011, documenting cross-sectional changes over time. As shown by Figure 1, there is substantial time variation. In the period of 1978 to 1983 we observe a slow trend of staggering up. This trend rapidly accelerates starting in 1984 until 1992. The period 1992 - 2006 is characterized by a fairly stable ratio of firms with a staggered board in the overall cross section, at around $60 \%$. After 2006 , the ratio of firms with a staggered board steadily declines, until reaching a percentage of about 45\% in 2011.

Figure 2 presents an analysis that aims to disentangle the time variation from the cross-sectional variation occurring from new firms entering the database. We do so by visualizing the dynamics of staggering up and staggering down within a specific group (cohorts) of firms through time, where no new firms are 
entering each cohort subsequently. Specifically, we study the dynamics of six cohorts of firms (hence six lines are shown in Figure 2): (i) firms with a staggered board in 1978, (ii) firms without a staggered board in 1978, (iii) firms with a staggered board in 1990, (iv) firms without a staggered board in 1990, (v) firms with a staggered board in 2000, and (vi) firms without a staggered board in 2000.

This approach allows us to distinguish three crucial sub-periods within our overall time period spanning from 1978 to 2011. The first, from 1978 to 1989, corresponds to the "takeover era"; the second, from 1990 to 2000, to the "bull market era"; and the third, from 2001 to 2011, to "the post-Enron era." Substantial corporate governance changes occurred across these sub-periods. The takeover era (i.e., 1978 -1989) saw the rise of activist investors (e.g., private equity firms) and the junk bond market, which together fueled the growth of takeover activity. On the other hand, this was also the era of the second generation of anti-takeover state legislation, which led to significant variation in the use of firm-level antitakeover defenses. The bull market era (i.e., 1990 - 2000) was characterized by rising stock prices and relatively few changes in shareholder rights and board structure. Finally, the post-Enron era (i.e., 2001 - 2011) has witnessed the introduction of substantial regulatory reforms at the federal level, as a result of both the corporate governance scandals of the early 2000s (leading to the adoption of the Sarbanes-Oxley Act) and the financial crisis of 2007 - 2009 (leading to the adoption of the Dodd-Frank Act).

With this motivation in mind for the choice of our sub-periods, we note that among the firms with a staggered board in 1978, only a few de-staggered until 2005, with nearly $93 \%$ remaining instead staggered in 2004 (out of the firms still in the sample). Starting from 2005, a large number of firms in this cohort have destaggered, with only about $71 \%$ of the surviving firms in this cohort remaining staggered in 2011.8 Conversely, among the firms without a staggered board in 1978, almost half have staggered-up from 1979 to 1989. About $40 \%$ of the firms in this cohort that adopted a staggered board in the early 1980 s de-staggered in the following years, with the number of firms that de-staggered past 2005 reaching nearly $30 \%$ of the cohort sample. ${ }^{9}$ Comparing the 1990 and 2000 cohorts to the 1978 cohort, we observe analogous trends. In

${ }^{8}$ The 1978 cohort of firms with staggered boards starts with 195 firms in 1978, from which 42 firms survive until 2011.

${ }^{9}$ The 1978 cohort of firms with no staggered board contains 684 firms in 1978, from which 146 firms survive until 2011. 
particular, among the firms with a staggered board in 1990 as well as among the firms with a staggered board in 2000, many have remained staggered until 2005 and began to increasingly de-stagger afterward. We thus note that when a firm staggers up, it typically takes a while before it decides to de-stagger. For example, none of the firms that staggered up in the early 2000s has de-staggered in recent years.

Lastly, we observe that over the 1995 - 2002 time period that has been the focus of most prior studies on staggered boards (e.g., Bebchuk and Cohen, 2005; Faleye, 2007; Bebchuk, Cohen, and Ferrell, 2009), there is almost no time variation. The lack of time series variation in the key variable of our analysis, Staggered $\operatorname{Board}_{[t]}$, in that period might thus be viewed as a limitation to those studies.

\section{Results}

\subsection{Staggered Boards and Firm Value}

We begin our empirical analysis with the study of the association between staggered boards and firm value, proceeding in four steps. First, we investigate the cross-sectional correlation between staggered boards and firm value as measured by Tobin's $Q\left(Q_{[t]}\right)$, replicating similar analyses in existing studies and, in particular, in Bebchuk and Cohen (2005). ${ }^{10}$ Second, we consider the time-series dimensions of the relation between staggered boards and firm value, using both pooled panel Tobin's $Q_{[t]}$ regressions including firm fixed effects and pooled panel first differences regressions. Third, we employ portfolio analysis, i.e., constructing portfolios of firms around the time a firm staggers up (down), as an additional method to verify the value impact of staggered boards. Fourth, in order to further investigate the sign change that we find between the cross-sectional and the time series analyses, we consider reverse causality.

We start with some preliminary observations. We selected our control variables so as to retain as many observations as possible. Thus, as compared to Bebchuk and Cohen (2005), who include in their regressions an extended set of controls (i.e., G-Index $\left[\text { [t-1], Ln }(G-I n d e x)_{[-1]}, \operatorname{Ln}(\text { Assets) })_{[-1]} \text {, Ln (Firm Age) }\right)_{[-1]}$, Delaware

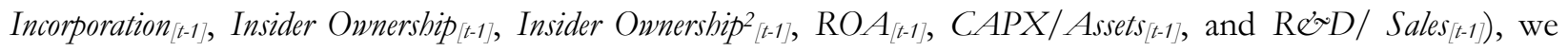

10 One difference in our cross-sectional analysis and the analysis of Bebchuk and Cohen (2005) is that they use industryadjusted Tobin's Q, defined as the firm's Q minus the median Q in the firm's industry in the observation year. Gormley and Matsa (2013), however, suggest that industry-adjusting of $Q$ may produce inconsistent estimates and can distort inference. For this reason, we use a fixed effects estimator at the industry level rather than industry-adjusting Q. 
exclude those controls that significantly reduce sample size. Specifically, we exclude Insider Ownership [t-1] $_{\text {(and }}$ the derived Insider Ownership2 $[t-1]), G$-Index $x_{[-1]}$ (and the derived Ln $\left(G\right.$-Index) $\left.{ }_{[-1]}\right)$, and Ln (Firm Age) $[[-1]$. In our robustness analysis, however, we employ the extended set of controls used in Bebchuk and Cohen (2005), and find that our results become qualitatively stronger. Additionally, as in Bebchuk and Cohen (2005), we exclude firms with a dual class structure from our analysis.

For all tables in this paper, we consistently show the t-statistics of all coefficients based on robust standard errors clustered by firm. For the staggered board coefficient, we also show the t-statistics based on robust standard errors that are not clustered. The motivation for employing standard errors clustered by firm is to incorporate the correlation of regression residuals across time for a given firm, which is common (Petersen, 2009).

\subsubsection{Cross-Sectional Analysis}

Table 3 presents the results of the value impact of staggered boards in the cross-section of firms. Since our full panel covers 34 years of data on Staggered Board $[t$, we are able to perform sub-sample analyses in order to establish robustness of cross-sectional results in different sample periods. Columns (1) through (5) present the results for each of the periods we consider: i.e., 1978 - 2011, 1978 - 1989, 1990 - 2000, 2001 - 2011, and 1995 - 2002. In particular, Column (1) presents results for our full time period, while Column (5) presents results for the same time period used in Bebchuk and Cohen (2005).

Consistent with the findings of Bebchuk and Cohen (2005), in Column (1) we find that the effect of Staggered Board $[t-1]$ on $Q_{[t]}$ is negative and both statistically and economically significant, leading to a $2.6 \%$ $(=-0.041 / 1.581)$ reduction in $Q_{[t]}$. We also note that statistical significance is robust across both the standard error adjustment techniques we employ. However, the t-statistics become smaller with clustering by firm, although they remain significant at the $5 \%$ confidence level. ${ }^{11}$

\footnotetext{
${ }^{11}$ For robustness, in the Online Appendix Table A.1, we also control the regressions of Table 3, column (1) for the extended set of controls used in Bebchuk and Cohen (2005). Specifically, in column (1) of Table A.1, we employ all the controls of the extended set except Insider Ownership ${ }_{[k-1]}$ (and Insider Ownership ${ }_{[k-1]}$ ), while in column (2) of Table A.1, we employ all the controls including Insider Ownership ${ }_{[k-1]}$ (and Insider Ownership ${ }_{[4-1]}$ ). For both columns the negative coefficient

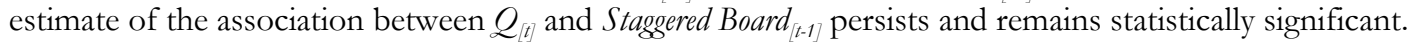


Next, we move to the analysis appearing in Column (5), which includes the same controls as in Bebchuk and Cohen (2005) and includes firm industry (using four-digit SIC codes) and year fixed effects. ${ }^{12}$ Reflecting the lack of time series variation, the coefficient estimate of Staggered Board $[\mathrm{t}-1]$ becomes insignificant with a tstatistics of 1.25 once we cluster the standard errors by firm. The economic significance, however, remains similar to that in Column (1), as having a staggered board is associated with a $2.7 \%(=-0.045 / 1.644)$ decrease in $Q_{[t]}$ in Column (5). Overall, these results are consistent with Bebchuk and Cohen (2005), though they report stronger economic and statistical significance (using robust standard errors that do not seem to be clustered).

Turning to the robustness of our cross-sectional results in different sample periods, we find similarly negative coefficient estimates of the association between $Q_{[t]}$ and Staggered Board $[t-1]$ across all the relevant subperiods (i.e., 1978 - 1989, 1990 - 2000, and 2001 - 2011). However, while coefficient estimates are strongly significant (at 1\% confidence level) during the 1990-2000 sample period, they become insignificant during both the 1978 - 1989 and 2001 - 2011 sample periods once we cluster standard errors by firm.

\subsubsection{Time Series Analysis}

While the results of Table 2 confirm that adopting of a staggered board is associated with lower firm value in the cross section, endogeneity concerns arise as to the direction of causation. As broadly acknowledged in the existing literature, these concerns emerge because governance arrangements are chosen in response to firm-specific circumstances (Adam, Hermalin, and Weisbach, 2010). Hence, it is unclear whether the identified negative association between staggered boards and firm value can be attributed to a causal link or, for example, to omitted-and-correlated variables. In particular, given the high autocorrelation of $Q_{[t},{ }^{13}$ it is possible that staggering decisions could be partly motivated by—rather than the cause of-low firm value. For example, firms with low value could decide to stagger up because they perceive themselves as

\footnotetext{
12 Bebchuk and Cohen (2005) use two-digit rather than four-digits SIC codes as we do. In robustness, however, we show that our results remain the same even using two-digit SIC codes or using the Fama - French 49 industry definitions.

${ }_{13}$ Note that while the first order auto-correlation coefficient of $Q_{[t]}$ is 0.869 , higher orders gradually decline. However, even the fifth order auto-correlation coefficient is still high, at 0.65 .
} 
more vulnerable to opportunistic raiders or to avoid interference by shareholders with short-term horizonsor indeed to entrench themselves.

We can significantly mitigate-though not eliminate-such endogeneity concerns by using the considerable time series variation in staggered boards. We first do so using pooled panel Tobin's Q regressions with firm fixed effects. Including the firm fixed effect is equivalent to removing the time-invariant component in both $Q_{[t]}$ and Staggered Boards $[t-1]$, therefore reducing the potential bias resulting from omitted time-invariant variables at the firm level. Once we include firm fixed effects, we are essentially comparing the average firm value before versus after a change in staggered boards, controlling for all the other firm characteristics and with year fixed effects included as well.

Table 4 presents our results with firm fixed effects (replicating Table 3 but substituting industry fixed effects with firm fixed effects). In contrast to the cross-sectional models, Table 4 shows a positive, statistically significant positive association between Staggered Board $[t-1]$ and $Q_{[t]}$. The economic magnitude of this positive association is also significant. In Column (1), for example, the adoption of a staggered board is associated with an increase in $Q_{[t]}$ of $3.7 \%(=0.059 / 1.581)$. The coefficient estimate of the staggered board in Column (1) is significant when clustering standard errors at the firm level, with a t-statistic of 2.11.14

Next, in Column (5), using the period and controls in Bebchuk and Cohen (2005), the estimated coefficient of Staggered Board $[t-1]$ is also positive and statistically significant at $10 \%$ confidence when clustering at the firm level. Economically, Column (5) presents even stronger significance, with the adoption of a staggered board being associated with a $7.2 \%$ increase in $Q_{[t]}(=0.119 / 1.644)$.

Across different sub-sample periods, we naturally find weaker results in periods where there are few changes in staggered boards. This is particularly the case of Column (3), which presents results for the time period 1990-2000 and where the Staggered Board $[-1]$ coefficient is insignificant. This should not be surprising, as

\footnotetext{
${ }^{14}$ For robustness, as with our cross-sectional analysis of staggered boards (see Section 4.1.1. above), in the Online Appendix Table A.1 we also control the regressions of Table 4, column (1) for the extended set of controls used in Bebchuk and Cohen (2005). Specifically, in column (3) of Table A.1 we employ all the controls of the extended set except Insider Ownership ${ }_{[-1]}$ (and Insider Ownership ${ }^{2}[t-1)$, while in column (4) of Table A.1 we employ all the controls including Insider Ownership $_{[t-1]}$ (and Insider Ownership ${ }^{2}{ }_{[t-1]}$ ). For both columns, the positive coefficient estimate of the association between $Q_{[t]}$ and Staggered Board $d_{[t]]}$ persists and remains statistically significant.
} 
the cohort analysis reported in Figure 2 above indicated very little variation in staggering-up (down) activity during the 1990 s.

We further investigate the time series dimension of the association between firm value and staggered boards by regressing changes in firm value (as measured by $\mathcal{Q}_{[t]}$ ) on changes in Staggered Board $[-1]$. We calculate the change in firm value both excluding (in Panel A of Table 5) and including (in Panel B of Table 5) the time period during which investors would likely have learned about the change in board structured. For example, say a firm has a staggered board at the end of fiscal year 2008 but not at the end of fiscal year 2009. That means that the board structure change in this example occurred somewhere during the fiscal year 2009. Therefore, we assume that investors learned about that change (as well as approved it) sometime over this 12month period. We do not try to get the timing exactly right, e.g., we do not consider an event study around the time the proxy gets released or is voted on, as there may be many other confounding issues happening during those same events. Rather, we consider the change in the firm value at either the end of the fiscal year after the change (in the example, the end of fiscal year 2009; results in Panel A of Table 5) or at the end of the fiscal year 12-months before the change (in the example, the end of fiscal year 2008; results in Panel B of Table 5), to the firm value $1,2,3,4$, up to 5 years later.

We regress those changes in firm value on the change in the staggered board status, in addition to the changes in the main controls. By examining a span of five years, we are able to study the long-term association of staggering decisions and firm value. Comparing how the change in value differs across time horizons is interesting, as it can show over what time period the average effects documented in Table 4 occur.

Panel A of Table 5 confirms that firm value, as proxied by Tobin's $Q_{[t]}$, increases following the adoption of a staggered board and decreases following a decision to de-stagger. Comparing the coefficient on the change in the staggered board across the five columns shows that the increase (decrease) in firm value after staggering up (down) occurs gradually in the first three years, rather than all in the first year. This suggests that market participants need some time to learn about the changed prospects of the firm that occur in the period following the change in board structure. The results in Column (1) of Panel B of Table 5 further show 
that during the "transition year" (in which stock market participants are likely to first learn and then approve of the board change) staggering up (down) is positively (negatively) associated with firm value.

The coefficients in both panels of Table 5 suggest that the positive time series association between staggered boards and firm value has an even stronger economic magnitude than that reported in Table 4. For example, in Column (3) of Panel A of Table 5, the adoption of a staggered board is associated with an increase in $Q$ over the next three years of $7.8 \%(=0.123 / 1.581)$, about double the magnitude found in the Column (1) of Table 4. We can reconcile these magnitudes as follows. First, when we use firm fixed effects in Table 4 , we are effectively comparing the average level of $\mathcal{Q}$ after the change to the average level of $\mathcal{Q}$ before the change, i.e., we are estimating an average effect before-versus-after. In Table 5, we are comparing the changes in the following years to only the level of $Q$ just before the change. Second, and more importantly, in Table 4 we control for many firm characteristics that absorb a lot of variation in $Q$, such as the level of profitability $(R O A)$ and R\&D expenditures (R\&D / Sales). In Table 5, instead, we do not control for changes in profitability after the change in board structure.

Table 5 also employs standard errors that are clustered at the firm level to correct for the autocorrelation in the dependent variable. As robustness, we also verify that our results are unchanged when we use the Newey-West estimator with up to six lags. ${ }^{15}$

\subsubsection{Portfolio Analysis}

So far, our time series analysis reveals that there is a statistically significant and economically meaningful positive time series relationship between staggered boards and $Q_{[t]}$. However, investors are unable to trade on $Q_{[t]}$. It is therefore of interest to verify whether the increase in Tobin's Q after adopting a staggered board is reflected in different stock prices (and vice versa as firms stagger down). To this end, following prior corporate governance studies (Gompers, Ishii, and Metrick, 2003; Bebchuk, Cohen, and Ferrell, 2009; and

\footnotetext{
${ }^{15}$ Lastly, for robustness, similarly to what we did for both our cross-sectional regressions and fixed effects regressions (appearing in Table 3 and 4, respectively), in the Online Appendix Table A.2, we replicate the analysis of Table 5, Panel $\mathrm{A}$ and $\mathrm{B}$ using the extended set of controls employed in Bebchuk and Cohen (2005). Specifically, in the odd columns of Panel A and B of Table A.2, we employ all the controls of the extended set except Insider Ownership [t-1] (and Insider

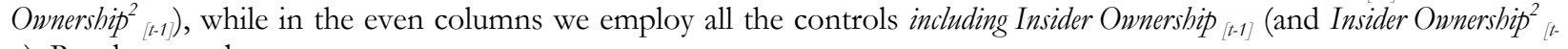
1]). Results are robust.
} 
Cremers and Ferrell, 2013b)), in Table 6 we study monthly portfolio returns. None of the portfolios we construct are tradable, in the sense that for none of the portfolios we are using only information for portfolio constructions that would have been publicly available at that time. Rather, our stock return analysis is a robustness check for our Q results.

We proceed by first constructing a portfolio that buys stock of firms around the time that they stagger up (the "long" portfolio) and another portfolio that buys stock of firms around the time that they de-stagger (the "short" portfolio). We then study the monthly excess returns (i.e., alpha) for these long and short portfolios. We consider three different ways to decide when exactly and how long to hold stock of firms surrounding changes in staggered board status. First (“6m12”), we include all stocks of firms that have (de)staggered their boards starting 6 months before the fiscal year-end date of the year in which the firm has reported its board being (de-)staggered for the first time, and hold these stocks for 12 months. Second (“12m12"), we include all stocks of firms that have (de-)staggered their boards starting 12 months before the fiscal year-end date of the year in which the firm has reported its board being (de-)staggered for the first time, and again hold these stocks for 12 months. Third ("12m24"), we include all stocks of firms that have (de)staggered their boards starting 12 months before the fiscal year-end date of the year in which the firm has reported its board being (de-)staggered for the first time, and hold these stocks for 24 months afterwards. Both " $12 \mathrm{~m} 12$ " and " $12 \mathrm{~m} 24$ " most likely include the period in which shareholders first learned about the proposed change and voted to approve the change. For " $6 \mathrm{~m} 12$ ", in many cases the changes in board structure will already be public knowledge at the time of portfolio construction.

We present results for excess returns based on three different pricing models: (i) the four factor Carhart (1997) model (i.e., we include the pricing factors of Momentum, HML, SMB, and market return), obtaining the monthly factor returns from the website of Ken French; (ii) the three-factor Fama-French model (i.e., HML, SMB, and market return), and (iii) the market model (i.e., only including the market return as in the CAPM). For each model, we present the returns to the long portfolio, short portfolio, and long minus short portfolio. 
Following Fama and French (2008), in Panel A of Table 6, we show equally weighted (EW) excess returns, while in Panel B of Table 6, we show value weighted (VW) excess returns. We construct the VW long-short portfolios following the same procedure we use for constructing the EW portfolios, which we have described above. As weighting factor for the stock returns, we use a firm's stock average market capitalization during the six months preceding the fiscal year-end date of the year in which the firm has reported its board being (de-)staggered for the first time. For example, if the event date is December $31^{\text {st }}$ 2001, we retrieve the average monthly market cap from June 2001 to November 2001. We calculate the market capitalization as the product of the outstanding shares and the share price on the closing trading day for each month, at the end of the calendar month during the six months preceding the staggering up (down) event date. Since the results we obtain for the EW long-short portfolios in Panel A are similar to those for the VW long-short portfolio in Panel B, to save space we limit the ensuing discussion to the former set of results.

As shown by Panel A of Table 6 using the four factor model, the monthly alpha to the long "6m12" portfolio is statistically significant at nearly 52 basis points. In contrast, the short portfolio return is not statistically significant at 6.2 basis points per month. The results are similar if we employ either the threefactor Fama-French model or the CAPM to estimate excess monthly returns to this portfolio. We observe a similar magnitude to the " $12 \mathrm{~m} 12$ " portfolios, with nearly 53 basis points monthly alpha for the long portfolio (although not statistically significant), but in this case we also find a negative monthly alpha of nearly 62 basis points to the short portfolio. Combined together, the long minus short " $12 \mathrm{~m} 12$ " portfolio has a monthly alpha of $1.24 \%$, which is statistically significant. ${ }^{16}$ Presented annually, the monthly excess return to the long minus short portfolio corresponds to nearly 16\% annual excess return. Finally, we obtain analogous results for the " $12 \mathrm{~m} 24$ " portfolio, under all three of the pricing models considered. Hence, the overall results of our portfolio analysis are consistent with our time series results, implying that adopting a staggered board increases both firm value and shareholder value, while de-staggering is not robustly associated with abnormal stock returns.

\footnotetext{
16 The returns on the long-short portfolio are not the same as the difference between the returns on the long and short portfolios. This is because when calculating the return on the long-short portfolio, we only use those months for which both the long and the short portfolio are not empty.
} 
While the stock returns have generally weak statistical significance (which may be due to the generally low number of stocks included in the portfolios), the economic magnitudes in Table 6 are generally consistent with earlier estimates. For example, in Panel A of Table 6, the EW long-short portfolio that buys (sells) stock of firms staggering up (down) surrounding the 24-month period around these changes in board structure generates an annual four-factor alpha of $5.15 \%$ (t-statistic of 1.44). That is quite similar to the economic magnitude associated with a change in staggered board for the 2-year change in Tobin's Q of 5.4\% $(=0.085 / 1.581)$ shown in Column 2 of Panel B of Table 5.

\subsubsection{Reverse Causality}

Our time series dimension and portfolio analyses suggest that the negative correlation identified in prior cross-sectional studies of the association of staggered boards with firm value might be due to reverse causality. In particular, if having a relatively low firm value induces some firms to adopt a staggered board (rather than a staggered board causing a low firm value), this could explain the cross-sectional result that firms with staggered boards tend to have low firm values. However, reverse causality cannot explain the time series results, as firm value tends to go up after the adoption of a staggered board. Neither can it explain the (statistically weak) portfolio analysis results, as a portfolio that is long in stocks of firms that have staggered up (the "long" portfolio) and short in stocks of firms that have de-staggered (the "short" portfolio) earns positive abnormal returns (both under equally-weighted portfolio analysis and value-weighted portfolio analysis).

To investigate this reverse causality hypothesis between Staggered Boards and $Q_{[t}$, we employ two different approaches. First, we consider whether staggering and de-staggering decisions are related to preexisting firm value. Second, we investigate the cross-sectional analysis controlling for lagged firm value.

Panel A (B) of Table 7 presents reverse causality regressions to explain the adoption (removal) of a staggered board. Our sample for Panel A (B) includes all firms that do not (do) have a staggered board up until and including the year in which they adopt (remove) a staggered board. Whenever a change in staggering (de-staggering) occurs in a firm, that firm is dropped from the sample two years after such a change. Each panel shows two different non-linear specifications: a random effects probit model and the Cox proportional 
hazard model where the change in board structure is the "failure" event. ${ }^{17}$ As everywhere else in the paper, we cluster the robust standard errors by firm. As shown by Column 2 in Panel A of Table 7, presenting results for the Cox model, a standard deviation increase in firm value is associated with a decrease of $57.8 \%$ in the probability of staggering up (with a t-statistics of 7.63). Similar results are obtained through the probit model (see Column 1), where a standard deviation increase in the value of $Q_{[t-1]}$ is associated with a $29.3 \%$ reduction in the probability of staggering up (with a t-statistic of 3.76). ${ }^{18}$

The results in Panel A of Table 7 suggest that the choice of staggering up is partly endogenous and motivated by a low firm value. Indeed, firms with high value may not need a staggered board because the risk of an opportunistic change of control or short-termist shareholder interference may be much lower for these firms. Concerning de-staggering decisions, Panel B of Table 7 shows that both specifications produce insignificant results. This indicates that firm value does not reliably predict staggering down.

As our second approach to investigate reverse causality, we add the one-year lagged $Q_{[t]}$ as an additional control to the pooled panel regressions with industry (but not firm) fixed effects regressions of Table 3. If reverse causality affects the cross-sectional results, we would expect the identified negative impact to become considerably weaker once we control for lagged firm value. This is confirmed in Table 8. In all specifications, the coefficient estimate of Staggered Board $[$ t-1] is insignificant once we control for lagged firm value. In addition, the coefficient magnitudes are significantly reduced relative to those in Table $3 .{ }^{19}$ We thus conclude that the cross-sectional results seem likely driven by reverse causality.

\subsection{A Positive Account of Staggered Boards}

Our time series results challenge the managerial entrenchment view of staggered boards, i.e. the view that sees staggering up decisions as a way to inefficiently isolate boards of directors from market discipline.

\footnotetext{
${ }^{17}$ See Greene (2004) on the efficiency of the random effects probit model estimator vs. the probit model fixed effects estimator.

18 Again, for robustness, in the Online Appendix Table A.3, we control the results of both the probit model and Cox model for the extended set of controls used in Bebchuk and Cohen (2005). Specifically, in Column (1) of Table A.3, we employ all the controls of the extended set except Insider Ownership ${ }_{[-1]}$ (and Insider Ownership ${ }_{[t-1]}^{2}$ ), while in Column (2) of Table A.3, we employ all the controls including Insider Ownership ${ }_{[t-1]}$ (and Insider Ownership ${ }_{[t-1]}^{2}$. In Column (3) and (4), we replicate the same additional controls for the Cox model. In each of the four columns, our results remain robust.

${ }_{19}$ As shown in Column (6) of the Online Appendix Table A.1, our results on the one-year lagged $Q_{[t]}$ are confirmed when we include the extended set of controls employed by Bebchuk and Cohen (2005).
} 
In particular, our main new finding that staggering up is associated with increased firm value casts a doubt on the claim that board insulation encourages value-decreasing, self-serving behaviors by incumbents.

In this section, we explore an alternative, positive account of staggered boards. In particular, we propose a hypothesis based on potential incentive problems in the shareholder-manager relationship. Under this hypothesis, staggered boards emerge in context of asymmetric information (or noisy market prices) as a response to the difficulty of firm insiders to share information about the firm's prospects when the firm has relatively low value. This is especially likely to be the case in firms with long-term, specific investments, which tend to be accompanied by high operational complexity. Indeed, shareholders may lack the incentives or the resources to investigate whether low short-term firm value is attributable to poor managerial performance or commitment to long-term projects that only decrease short-term (but not long-term) earnings. Anticipating that low firm value may lead to removal from the board, directors may adopt a myopic, short-termism perspective in order to appease shareholders. On this view, the adoption of a staggered board could help make directors less susceptible to myopic incentives and encourage a longer-term commitment to firm value creation.

To test this hypothesis, in the following sections we revisit out time series analysis results by conditioning the effect of Staggered Board $[t-1]$ on $Q_{[t]}$ on various firm-level features that relate to a firm's investment policy and operational complexity, board and governance features, and executive compensation incentives.

\subsubsection{Staggered Boards, Investments, and Operational Complexity}

We first consider the main conjecture in our positive account of staggered boards, namely whether the time series positive association between staggering up and firm value is stronger for firms that have more long-term, specific investments and higher operational complexity. As variables of interest, we consider ReD/ Sales $[t]$, Intangible Assets/ Total Assets $[t]$, Ranked Patent Citation Count $[t]$, and Firm Size $[t]$ (all defined in Table 1). Our positive account of staggered boards would suggest that the positive association between staggering up and increased firm value is stronger for firms with (i) higher R\&D expenses as a fractions of their revenues; (ii) more intangible assets; (iii) more patent citation counts (as a proxy for innovation, following 
Hall, Jaffe, and Trajtenberg, 2001); and (iv) larger size (as a measure of complexity, following Faleye, 2007; and Core, Holthausen, and Larcker, 1999).

Table 9 shows the results of our interaction analysis. The odd columns present the interaction impact on $Q_{[t]}$ of Staggered Board $[t-1]$ and the above variables of interests, ${ }^{20}$ while the even columns only consider the direct effect of such variables on $Q_{[t]}$ and do not include the interaction. The results in Table 9 strongly support our conjectures.

For example, the interaction of $R \Theta D / S_{\text {ales }[t-1]}$ (see column 1) has a positive and both statistically and economically significant coefficient. Firms whose $R \Theta D / S$ ales $[t-1]$ is one standard deviation higher than the mean (i.e., "high $\mathrm{R} \& \mathrm{D}$ " firms) experience a $10.8 \%$ higher level of $Q_{[t]}$ after staggering up relative to firms whose R\&D/Sales $[-1]$ is at the mean. ${ }^{21}$ Remarkably, as compared to the direct economic effect of Staggered

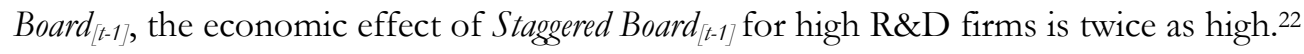

Similarly, we find that firms with Intangible Assets/ Total Assets $[-1]$ that are one standard deviation higher than the mean present a $3.96 \%$ higher $Q_{[t]}$ if they stagger up relative to firms with average intangible assets. Consistently, firms that have one standard deviation higher Ranked Patent Citation Count $t_{[-1]}$ have a 4.97\% higher $Q_{[t]}$ if they stagger up compared to firms with mean (i.e., very low) patent counts.

These findings supports our hypothesis that staggered boards are especially beneficial in firms whose investment programs or assets require time and thus longer-term ex ante commitment to be optimally developed. These findings also appear consistent with the literature documenting that investors regularly underestimate the benefits of R\&D investments in the short-term (Chan, Lakonishok, and Sougiannis, 2001; Eberhart, Maxwell, and Siddique, 2004) and may even exert pressure to reduce such investments in order to boost short-term earnings (Bushee, 1998). Viewed through this lens, the adoption of a staggered board would provide a means to address inefficiencies that can arise in contexts where the innovative and/or firm-specific

\footnotetext{
${ }^{20}$ All the continuous variables in the interaction terms (i.e., R $\sigma D /$ Sales $_{[t]}$, Intangible Assets/ Total Assets $[t]$, and Firm Size $\left.[t]\right)$ are demeaned prior to calculating the interaction.

21 We obtain this estimation by multiplying the coefficient of the interacting variable (i.e., 1.962) by the standard deviation of $\operatorname{R} \approx D /$ Sales $_{[t}$, divided by the average $Q_{[t]}$ in the sample of observations used to estimate Column (1).

${ }^{22}$ The economic effect of Staggered Board ${ }_{[t-1]}$ on $Q_{[t]}$ for all firms in Column (1) is a $4.49 \%$ increase of $Q_{[t]}$, calculated as the ratio of the coefficient estimate of 0.076 on Staggered Board ${ }_{[t-1]}$ divided by the average $Q_{[t-1]}$.
} 
nature of a firm's investments makes it more likely that asymmetric information may distort the relationship with the firm's investors.

Turning to complexity, firms whose Firm Size $[t]$ is one standard deviation higher than the average tend to have a $3.4 \%$ higher $Q_{[t]}$ if they stagger up relative to firms with average size. Based on the premise that larger firms are inherently more complex than smaller ones (Gabaix and Landier, 2008; Faleye, 2007), this result suggests that directors who do not have to stand annual (re)elections are in a better position to manage firms with a high level of operational complexity, most likely because the oversight of large, complex firms tends to involve a long-term outlook that is incompatible with frequent shareholder interference and the potential for myopic director incentives that can arise therefrom. ${ }^{23}$

\subsubsection{Staggered Boards and Corporate Governance}

An alternative explanation for the positive association between staggering up and firm value is that firms that stagger up may simultaneously decrease other entrenching governance mechanisms. Similarly, the decision to adopt a staggered board may be primarily taken by firms whose other corporate mechanisms provide strong safeguards against managerial entrenchment. To verify this alternative explanation, we interact Staggered Board $[-1]]$ with two proxies for managerial entrenchment: CEO-Board Chairman Duality $[-1]$, and the $G^{-}$ index ${ }_{[-1]}$ (all defined in Table 1) in pooled panel Q regressions with firm and year fixed effects.

CEO-Board Chairman Duality $[t]$ refers to the duality of the CEO and board chairman roles. CEOs who also chair the board of directors seem better positioned to opportunistically dominate the board (Brickley, Coles, and Jarrell, 1997). Alternatively, CEO-duality may be a consequence of well-performing CEOs being rewarded. Under this hypothesis, CEO duality is therefore a proxy for the firm being managed effectively (Adams, Hermalin, and Weisbach, 2010). The other proxy that we use is the G-index $[t-1]$ of Gompers, Ishii and Metrick (2003), which is a standard proxy of limitations to shareholder rights, as explained in Section 3 above. Similar to Table 9, we show the impact of the interacted variables on $Q_{[t]}$ in odd columns.

${ }^{23}$ As shown in the Online Appendix Table A.4, our results on the interactions with R $\approx D /$ Sales $[t]$, Intangible Assets/ Total Assets $_{[t]}$, Ranked Patent Citation Count $[t]$, and Firm Size $[t]$ are confirmed when we include the extended set of controls employed by Bebchuk and Cohen (2005). 
The interaction of CEO-Board Chairman Duality $[-1]$ with the staggered board dummy (in Column (1)) is positive and significant. Hence, firms with dual CEO-board chairman experience a larger increase in value if they stagger up relative to firms whose CEO does not also chair the board. A possible explanation, which is also consistent with the hypothesis of Adams, Hermalin, and Weisbach (2010), is that managing longer-term projects (i.e., one potential reason to stagger up) is relatively complex and thus better accomplished by talented CEOs, who have earned the privilege of chairing the board of directors. As shown in Column (2), the coefficient on CEO-chair duality by itself is positive, such that the firm value tends to go up (down) if the CEO starts (leaves) as chair of the board. However, the coefficient on the CEO-chair duality dummy becomes insignificant once its interaction with a staggered board is included in Column (1). Therefore, changes in CEO-chair duality are only related to changes in firm value for firms with a staggered board.

The coefficient of the interactions of $G$-index $[$-1] (in Column (3)) is insignificant. This suggests that the positive impact of staggering up on firm value cannot be explained by the simultaneous decrease of other entrenching mechanisms. In other words, we find that the change in firm value before versus after the adoption / removal of a staggered board is independent of the level of shareholder rights at the firm. However, consistent with Cremers and Ferrell (2013), the non-interacted effect of $G$-index $[t-1]$ on firm value (in Columns (3) and (4)) remains negative and significant even if firm fixed effects are included. ${ }^{24}$

\subsubsection{Staggered Boards and Executive Compensation}

In this subsection we consider whether the positive (negative) association between the adoption (removal) of a staggered board and firm value is related to strong equity-based incentives that guard against managerial entrenchment. As proxies of such incentives, we include CEO Delta $[t]$ and CEO Vega $[t$. In testing the impact of the interaction of Staggered Board $[-t]$ and these variables on $Q_{[t}$, our positive account of staggered boards would suggest that firms with a staggered board are better able to provide incentives for effective, long-term managerial risk-taking. Therefore, we conjecture that stronger CEO incentives will be more positively associated with increases in firm value if the firm staggers up. Put differently, if staggering up is

24 As shown in the Online Appendix Table A.5, our results on the interactions with CEO Turnover $[$-1] , CEO-Board Chairman Duality $[t-1]$, and the G-index $[t-1]$ are confirmed when we include the extended set of controls employed by Bebchuk and Cohen (2005). 
partly done because of the need for a longer-term outlook on the board, then strong risk-taking incentives for the CEO may become more productive after the board staggers up (and vice versa if the board de-staggers).

Table 11 shows our results. For CEO Delta $[$ t-1], we find that the interacted coefficient is insignificant while CEO Delta $[t]$ by itself is positive and highly significant. This suggests that increases in pay-forperformance are positively related to changes in firm value, but similarly for firms with and without a staggered board. However, the interaction between a staggered board and CEO Vega is strongly and positively related to the firm value. Specifically, firms with CEO Vega $[-1]$ that is one standard deviation above the mean have an increase in firm value that is $5.53 \%$ higher if they stagger up relative to firms with average CEO Vega.

These result confirm our conjecture that staggering up is complementary to strong risk-taking incentives, especially incentives to increase the long-run riskiness of the firm's cash flows (which seems better measured by CEO Vega than CEO Delta).

Finally, we also investigate the interaction of Staggered Board $[t-1]$ with CEO Total Compensation $[t]$, to consider the view that high executive compensation itself is evidence of managerial entrenchment and more so in the presence of a staggered board. Our results are not consistent with this view. Rather, when we add the interaction of the adoption of a staggered board with the level of total CEO compensation to firm value regressions, this interaction has a strongly positive impact on firm value. Economically, firm with CEO Total Compensation $[t]_{\text {that }}$ is one standard deviation above the mean have an increase in firm value that is $5.43 \%$ higher if they stagger up relative to firms with average total CEO compensation. Consistent with the interpretation of the findings of Gabaix and Landier (2008), namely that more skilled managers manage large firms that pay them more, this result suggests that staggered boards may be more valuable at firms with a high-pay CEO, potentially because these CEOs are particularly talented at the challenging task of running complex, large organizations with a long-term outlook. ${ }^{25}$ Nota come sopra, Appendix Table 6.

25 As shown in the Online Appendix Table A.6, our results on the interactions with CEO Delta $[t]$, CEO Vega $a_{[t}$, and CEO Total Compensation $[t]$, are confirmed when we include the extended set of controls employed by Bebchuk and Cohen (2005). 


\section{Robustness Analysis}

Our robustness analysis addresses two concerns. First, as previously noted, for most of our analysis we use a basic set of control variables including $\operatorname{Ln}\left(\right.$ Assets) $_{[t-1]}$, Delaware Incorporation ${ }_{[t-1]}, R O A_{[t-1]}, C A P X /$ Assets $_{[t-1]}$, and ReD/ Sales $[t-1]$. This empirical strategy is motivated by the fact that including the extended set of control variables appearing in Bebchuk and Cohen (2005) comes at the cost of a significantly reduced sample size. To give a tangible example, including the extended set of controls in Column (1) of Table 4 would reduce the sample size from 31,574 observations to 14,376 observations. For robustness, we check whether including the extended set of controls changes our results qualitatively. We present these results in the Online Appendix to save space. To this end, we add to all the regressions presented in Tables 3 through 5 and in Tables 7 through 11 the following controls: G-Index $[t-1]$, Ln $(G-I n d e x)_{[t-1]}$, Ln (Firm Age $)_{[-1]}$, Insider Ownership $[t-1]$, and Insider Ownership ${ }^{2}[t-1] \cdot{ }^{26}$

We find that our results are preserved when we use the extended set of controls. More specifically, in almost every specification the coefficient estimate of the staggered board dummy becomes economically stronger. For example, when we add the additional variables to the specification in Column (1) of Table 4, we find that the Staggered Board $[-1]$ coefficient increases to 0.115 with an associated t-statistic of 2.64 , compared to a coefficient of 0.059 and a t-statistic of 2.11 in Table 4.

Second, because of the persistence of the dependent variable over time, a possible concern is that some of the coefficients presented in the first difference analysis (Table 5) could be inflated by the autocorrelation in the residuals. For example, the dependent variable of $\Delta Q_{[t, t+5]}$ is highly correlated with its value at time $\mathrm{t}-1$

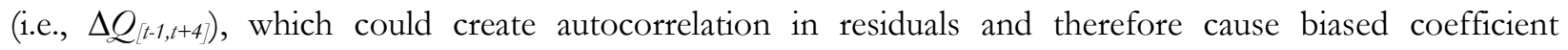
estimates. To address this concern, we verify that these results are robust to controlling for either $\Delta Q_{[t-1, t]}$ or $Q_{[[-1]}$ in Panel A $\left(\Delta Q_{[t-2, t-1]}\right.$ or $Q_{[t-2]}$ in Panel B). These additional tests confirm our findings that the relationship between $\Delta Q_{[, t+1]}$ and $\Delta$ Staggered Board $[t-1, t]$ is positive and statistically significant.

\footnotetext{
${ }^{26}$ In particular Insider Ownership ${ }_{[t-1]}$ reduces sample size the most. For example, in Table 4, Column (1), including the extended set of controls but Insider Ownership ${ }_{[t-1]}$ (and Insider Ownership ${ }_{[t-1]}$ ) increases the sample size from 14,376 observations to 19,743 observation.
} 


\section{Conclusion}

In this paper, we have revisited the common view in corporate governance that adopting a staggered board lowers firm value and that it is generally preferable to de-stagger. Using a comprehensive data on staggered boards in 1978-2011 for a panel of U.S. firms, we find that the negative cross-sectional association between staggered boards and firm value is reversed in the time series analysis.

These surprising results are very robust. Using both pooled panel Tobin's Q regressions with firm fixed effects and first differences regressions of changes in Tobin's $Q$ and changes in whether the firm has a staggered board, we find that firm value goes up upon the adoption of a staggered board and goes down upon removal of a staggered board. In particular, using firm fixed effect regressions, we find that staggering up (down) is associated with an increase (decrease) in Tobin's Q of about 6.3\%. We further corroborate these results using stock returns of portfolios holding stocks of firms around the time the firm staggers up or staggers down, and find that stocks that stagger up tend to have positive abnormal returns around the time they adopt a staggered board. In contrast, stocks that de-stagger tend to have no or negative abnormal returns.

These results challenge the common understanding that staggered boards are primarily a mechanism to help entrench management from the discipline of stockholders or the market of corporate control. In addition, they question the guidelines of the shareholder voting (proxy) advisors that generally recommend to vote against the adoption of a staggered board and, likewise, in favor of the removal of a staggered board (ISS, 2013; Glass Lewis, 2013). For example, the proxy guidelines for the 2013 season of Glass Lewis (i.e., one of the two most prominent proxy advisors in the world, the other being the ISS) state that they "favor the repeal of staggered boards and the annual election of directors. We believe staggered boards are less accountable to shareholders than boards that are elected annually. Furthermore, we feel the annual election of directors encourages board members to focus on shareholder interests."

How can we interpret our evidence that the adoption of a staggered board is associated with an increase in firm value? We first try to reconcile the seemingly conflicting existing cross-sectional evidence with our new time series evidence. We find that the cross-sectional results in this and in prior studies - that in the cross-section, staggered boards tend to have a lower value - could be explained by the reverse causality 
embedded in the choice of adopting a staggered board. In particular, our evidence suggests that firms with low firm value are more likely to adopt a staggered board.

Second, we propose a positive account of staggered boards, in which staggering up may be efficiently employed by some firms to mitigate the risk of interference by shareholders with a short-term investment horizon and/or the risk of takeovers from opportunistic raiders. While short-term pressure from stockowners may generally provide an efficient mechanism to discipline management and the board, in the specific context of high asymmetric information (or very noisy market prices) such market discipline may have adverse consequences. For example, it may be very difficult for firm insiders to credibly signal to investors that decreased short-term earnings are due to significant long-term and profitable investment programs rather than to poor managerial performance. In addition, investors with short-term investment horizons may have poor incentives to expend considerable resources to address such information problems, especially for large, complex firms. In particular, Cremers, Pareek, and Sautner (2013) document that the average institutional holding duration (i.e., the average length of time a stock is held in an institutional portfolio) is about 1.5 years with about $40 \%$ of holdings having a duration below 1 year, which seem well below the typical time horizons over which the uncertain prospects of large capital expenditures are revealed.

In this context, the board is likely to be better informed than outside shareholders. As a result, shortterm shareholder pressure may potentially induce managerial myopia and overinvestment in short-term projects at the expense of value-enhancing long-term ones. A staggered board may therefore be beneficial to insulate the board from such shareholder pressure and promote longer-term commitment to value creation. Consistent with this conjecture, we find that adopting a staggered board has a more positive effect on firm value for firms where such shareholder-manager problems may be more important, such as firms with higher $\mathrm{R} \& \mathrm{D}$, more intangible assets, more innovative research, and firms that are larger and thus more complex.

From a broader perspective, these results cast a doubt on recent academic and regulatory proposals in favor of shareholder empowerment, suggesting that in corporate contexts where asymmetric information and long-term investments play a crucial role (as they do in many modern large firms), shareholders interference risks being detrimental rather than beneficial. To the best of our knowledge, we are also the first to challenge the claim (see, e.g., Bebchuk, 2013), that the empirical evidence decidedly supports the adoption of a 
shareholder-driven corporate governance model. In contrast to this claim, our results seem to suggest that the traditional director primacy model as enforced by the courts of Delaware (i.e., vesting the authority to run the corporation on the board of directors and reserving to shareholders only a secondary role) can efficiently serve the interests of shareholders and society as whole. 


\section{References}

Adams, R., Almeida H, and D. Ferreira, 2005, Powerful CEOs and Their Impact on Corporate Performance, Review of Financial Studies, Vol. 18(4): 1403-32.

Adams, R., B. E. Hermalin, and M. S. Weisbach, 2010, The Role of Boards of Directors in Corporate Governance: A Conceptual Framework and Survey, Journal of Economic Literature, Vol. 48(1): 58-107.

Ahn, S. and K. Shrestha, 2012, The Differential Effects of Classified Boards on Firm Value, working paper.

Bainbridge, S., 2006, Directory Primacy and Shareholder Disempowerment, Harvard Law Review, Vol. 119: 1735-1749.

Bates, T., D. Becher, and M. Lemmon, 2008, Board Classification and Managerial Entrenchment: Evidence from the Market for Corporate Control, Journal of Financial Economics, Vol. 87: 656-677.

Bratton, W. W. and M. L. Wachter, 2010, The Case Against Shareholder Empowerment, University of Pennsylvania Law Review, Vol. 158: 653-728.

Bebchuk, L. A. and J. Fried, 2004, Pay Without Performance: The Unfulfilled Promise of Executive Compensation.

Bebchuk, L. A., 2005, The Case for Increasing Shareholder Power, Harvard Law Review, Vol. 118: 833917.

Bebchuk, L. A., 2007, The Myth of the Shareholder Franchise, Virginia Law Review, Vol. 93: 675-732.

Bebchuk, L. A., 2013, The Myth that Insulating Boards Serves Long-term Value, Columbia Law Review, Vol. 113: forthcoming.

Bebchuk, L. A., J. Coates, and G. Subramanian, 2002, The Powerful Antitakeover Force of Staggered Boards: Theory, Evidence \& Policy, Stanford Law Review, Vol. 54: 887-951.

Bebchuk, L. A. and A. Cohen, 2005, The Costs of Entrenched Boards, Journal of Financial Economics, Vol. 78: 409-433.

Bebchuk, L. A., A. Cohen, and A. Ferrell, 2009, What Matters in Corporate Governance?, Review of Financial Studies, Vol. 22: 783-827.

Bebchuk, L. A. and Y. Grinstein, 2005, The Growth in Executive Pay, Oxford Review of Economic Policy, Vol. 21: 283-303.

Bhagat, S. and R. Romano, 2002a, Event Studies and the Law: Part I: Technique and Corporate Litigation, American Law and Economics Review, Vol. 4: 141.

Bhagat, S. and R. Romano, 2002b, Event Studies and the Law: Part II: Empirical Studies of Corporate Law, American Law and Economics Review, Vol. 4:380.

Blair, M. M. and Stout, L. A., 1999, A Team Production Theory of Corporate Law, Virginia Law Review, Vol. 85: 247-286.

Bratton W. W. and M. L. Wachter, 2010, The Case against Shareholder Empowerment, University of Pennsylvania Law Review, Vol. 158: 653-728.

Brickley, James A., Jeffrey L. Coles, and Gregg A. Jarrell, 1997, Leadership Structure: Separating the CEO and Chairman of the Board, Journal of Corporate Finance, Vol. 3: 189-220.

Bushee B., 1998, The Influence of Institutional Investors on Myopic R\&D Investment Behavior, The Accounting Review, Vol. 73: 305-333.

Carhart, M. M., 1997, On Persistence in Mutual Fund Performance, The Journal of Finance, Vol. 52: 57-82. 
Chan, S.H., Martin, J.D., Kensinger, J.W., 1990, Corporate Research and Development Expenditures and Share Value, Journal of Financial Economics, Vol. 26: 255-276.

Chan, L. K. C., J. Lakonishok, and T. Sougiannis, 2001, The Stock Market Valuation of Research and Development Expenditures, Journal of Finance, Vol. 56(6): 2431-56.

Chauvin, K. W., and M. Hirschey, 1993, Advertising, R\&D Expenditures and the Market Value of the Firm. Financial Management, Winter, 128-140.

Cohen, A., and C. Wang, How Do Staggered Boards Affect Shareholder Value? Evidence from a Natural Experiment, Journal of Financial Economics, forthcoming.

Core, J. E., and W. R. Guay, 2002, Estimating the Value of Employee Stock Option Portfolios and their Sensitivities to Price and Volatility, Journal of Accounting Research Vol. 40: 613-629.

Core, J. E., R. W. Holthausen, and D. F. Larcker, 1999, Corporate Governance, Chief Executive Officer Compensation and Firm Performance, Journal of Financial Economics, Vol. 51: 371-406.

Cremers, K.J.M., and Y. Grinstein, 2013, Does the Market for CEO Talent Explain CEO Controversial Pay Practices?, Review of Finance, forthcoming.

Cremers, K.J.M. and A. Ferrell, 2013, Thirty Years of Shareholder Rights and Firm Valuation, Journal of Finance, forthcoming.

Cremers, K.J.M. and A. Ferrell, 2013b, Thirty Years of Shareholder Rights and Stock Returns, working paper.

Cremers, K.J.M., and V. Nair, 2005, Governance Mechanisms and Equity Prices, Journal of Finance, Vol. 60: 2859-2894.

Cremers, K.J.M., A. Pareek, and Z. Sautner, 2013, Stock Duration and Overvaluation, working paper.

Daines, R.M., 2001, Does Delaware Law Improve Firm Value? Journal of Financial Economics, Vol. 62: 525558.

DeAngelo, H., and E. M. Rice, 1983, Antitakeover Charter Amendments and Stockholder Wealth, Journal of Financial Economics, Vol. 11: 329-359.

Dey, A., E. Engel, and X.G. Liu, 2011, CEO and Board Chair Roles: To Split or not to Split? Journal of Corporate Finance, Vol. 17: 1595-1618.

Demsetz, H., and K. Lehn, 1985, The Structure of Corporate Ownership: Causes and Consequences, Journal of Political Economy, Vol. 93: 1155-1177.

Eberhart, A.C., Maxwell, W.F., Siddique, A.R., 2004, An Examination of Long-term Abnormal Stock Returns and Operating Performance Following R\&D Increases, Journal of Finance Vol. 59: 623-650.

Fama, E. and K. French, 1992, The Cross-section of Expected Stock Returns, Journal of Finance, Vol. 47:427-465.

Fama, E. and K. French, 2008, Dissecting Anomalies, Journal of Finance, Vol. 53: 1653-1678.

Faleye, O., 2007, Classified Boards, Firm Value, and Managerial Entrenchment, Journal of Financial Economics, Vol. 83: 501-529.

Gabaix, X. and A. Landier, 2008, Why has CEO Pay Increased So Much? The Quarterly Journal of Economics, Vol. 123: 49-100.

Glass Lewis \& Co., 2013, Proxy Paper Guidelines - 2013 Proxy Season: An Overview of the Glass Lewis Approach to Proxy Advice (United States), see http://www.glasslewis.com/issuer/guidelines/

Gomplers, P., J. Ishii, A. Metrick, 2003, Corporate Governance and Equity Prices, Quarterly Journal of Economics, Vol. 118: 107-155. 
Gomplers, P., J. Ishii, A. Metrick, 2008, Extreme Governance: An Analysis of Dual-Class Companies in the United States, Review of Financial Studies.

Gormley, T. and D. Matsa, 2013, Common Errors: How to (and Not to) Control for Unobserved Heterogeneity, Review of Financial Studies, forthcoming.

Goyal, Vidhan K., and Chul W. Park, 2002, Board Leadership Structure and CEO Turnover, Journal of Corporate Finance, Vol. 8: 49-66.

Graham, J. R., C. Harvey, and S. Rajgopal, 2005, The Economic Implications of Corporate Financial Reporting, Journal of Accounting and Economics, Vol. 40 (1): 3-73.

Greene, W., 2000, Econometric Analysis, Fourth Edition, Prentice Hall.

Greene, W., 2004, The Behavior of the Fixed Effects Estimator in Nonlinear Models, The Econometrics Journal, Vol. 7: 98-119.

Grossman, S. J., and O. D. Hart, 1983, An Analysis of the Principal-Agent Problem, Econometrica, Vol. 51: 7-45.

Hall, B. H., A. B. Jaffe, and M. Trajtenberg, 2001, The NBER Patent Citation Data File: Lessons, Insights and Methodological Tools, NBER Working Paper 8498.

Hirschey, M., 1982, Intangible Capital Aspects of Advertising and R\&D Expenditures. Journal of Accounting Research, Vol. 30: 375-390.

Holmstrom, B., 1979, Moral Hazard and Observability, Bell Journal of Economics, Vol. 10: 74-91.

Hubbard, R. G., 2005, Pay Without Performance: a Market Equilibrium Critique, The Journal of Corporate Law, Vol. 30: 717-720.

ISS (Institutional Shareholder Services, Inc.), 2013, U.S. Proxy Voting Summary Guidelines, accessed online at http://www.issgovernance.com/files/2013ISSUSSummaryGuidelines1312013.pdf 48.

Jensen, M.C., 1988, Takeovers: Their Causes and Consequences, Journal of Economic Perspective, Vol. 2: 21-

Jensen, M.C., 1993, The Modern Industrial Revolution, Exit, and the Failure of Internal Control Systems, Journal of Finance, Vol. 48: 831-880.

Jensen, M. C. and K. J. Murphy, 1990a, CEO Incentives: It's Not How Much You Pay, but How, Harvard Business Review, Vol. 68: 138-153.

Jensen, M.C. and K.J. Murphy, 1990b, Performance, Pay and Top-Management Incentives, Journal of Political Economy, Vol. 98: 225-264.

Jenter, D. and F. Kanaan, 2010, CEO Turnover and Relative Performance Evaluation, Journal of Finance, Vol. 65.

Karpoff, J., and P. Malatesta, 1989, The Wealth Effects of Second Generation State Takeover Legislation, Journal of Financial Economics, Vol. 25: 291-322.

Koppes, R.H., Ganske, L.G., and Haag, C.T., 1999, Corporate Governance Out of Focus: the Debate over Classified Boards, Business Lanyer, Vol. 54: 1023-1055.

Laffont, J.J. and J. Tirole, 1988, Repeated Auctions of Incentive Contracts, Investment and Bidding Parity, with an Application to Takeovers, RAND Journal of Economics, Vol. 19: 516-537.

Lang, L. and R. Stulz, 1994, Tobin's Q, corporate Diversification, and Firm Performance, Journal of Political Economy, Vol. 102: 1248-1280.

Larcker, D.F., G. Ormazabal, and D.J. Taylor, 2011, The Market Reaction to Corporate Governance Regulation, Journal of Financial Economics, Vol. 101: 431-448. 
Lev, B and T. Sougiannis, 1996, The Capitalization, Amortization and Value Relevance of R\&D, Journal of Accounting and Economics, Vol. 21: 107-138.

Lipton, M. and S. Rosenblum, 1991, A New System of Corporate Governance: The Quinquennial Election of Directors, University of Chicago Law Review, Vol. 58: 187-253.

Lipton, M., T. N. Mirvis, D.A. Neff, and D. A. Katz, 2012, Harvard's Shareholder Rights Projects is Wrong, The Harvard Law School Forum On Corporate Governance and Financial Regulation, March 23, 2012,

Mahoney, J.M., Mahoney, J.T., 1993, An Empirical Investigation of the Effect of Corporate Charter Antitakeover Amendments on Stockholder Wealth, Strategic Management Journal, Vol. 14: 17-32.

Manne, H., 1965, Mergers and the Market for Corporate Control, Journal of Political Economy, Vol. 75: $110-118$.

Masulis, R., C. Wang, and F. Xie, 2007, Corporate Governance and Acquirer Returns, Journal of Finance, Vol. 62: 1851-1859.

Morck, R., A. Shleifer, and R. Vishny, 1988, Management Ownership and Market Valuation: an Empirical Analysis, Journal of Financial Economics, Vol. 20: 293-315.

Porter, M., 1992, Capital Disadvantage: America's Failing Capital Investment System, Harvard Business Review, Vol. 70: 65-82.

Shavell, S., 1979, Risk Sharing and Incentives in the Principal and Agent Relationship, Bell Journal of Economics, Vol. 10: 55-73.

Shleifer, A. and R. W. Vishny, 1990, Equilibrium Short Horizons of Investors and Firms, American Economic Review Papers and Proceedings, Vol. 80: 148-153.

Stein, J., 1988, Takeover Threats and Managerial Myopia, Journal of Political Economy, Vol. 96(1): 61-80.

Stein, J. C., 1989, Efficient Capital Markets, Inefficient Firms: A Model of Myopic Corporate Behavior, The Quarterly Journal of Economics, Vol. 104: 655-669.

Strine, L. E., 2006, Toward a True Corporate Republic: A Traditionalist Response to Bebchuk's Solution for Improving Corporate America, Harvard Law Review, Vol. 119: 1759-1783.

Tirole, J., 2006, The Theory of Corporate Finance.

Weisbach, Michael S., 1988, Outside Directors and CEO Turnover, Journal of Financial Economics, Vol. 20: 431-60.

Yermack, David, 1996. Higher Market Valuation of Companies with a Small Board of Directors, Journal of Financial Economics, Vol. 40: 185-211.

Zingales, L., 2000, In Search of New Foundations, Journal of Finance, Vol. 55:1623-1653. 
FIGURE 1:

PERCENTAGE OF FIRMS WITH A STAGGERED BOARD

The chart below shows the percentage of firms with a staggered board in our sample, each year from $1978-$ 2011. Excluded from the sample are stocks that have dual class shares.

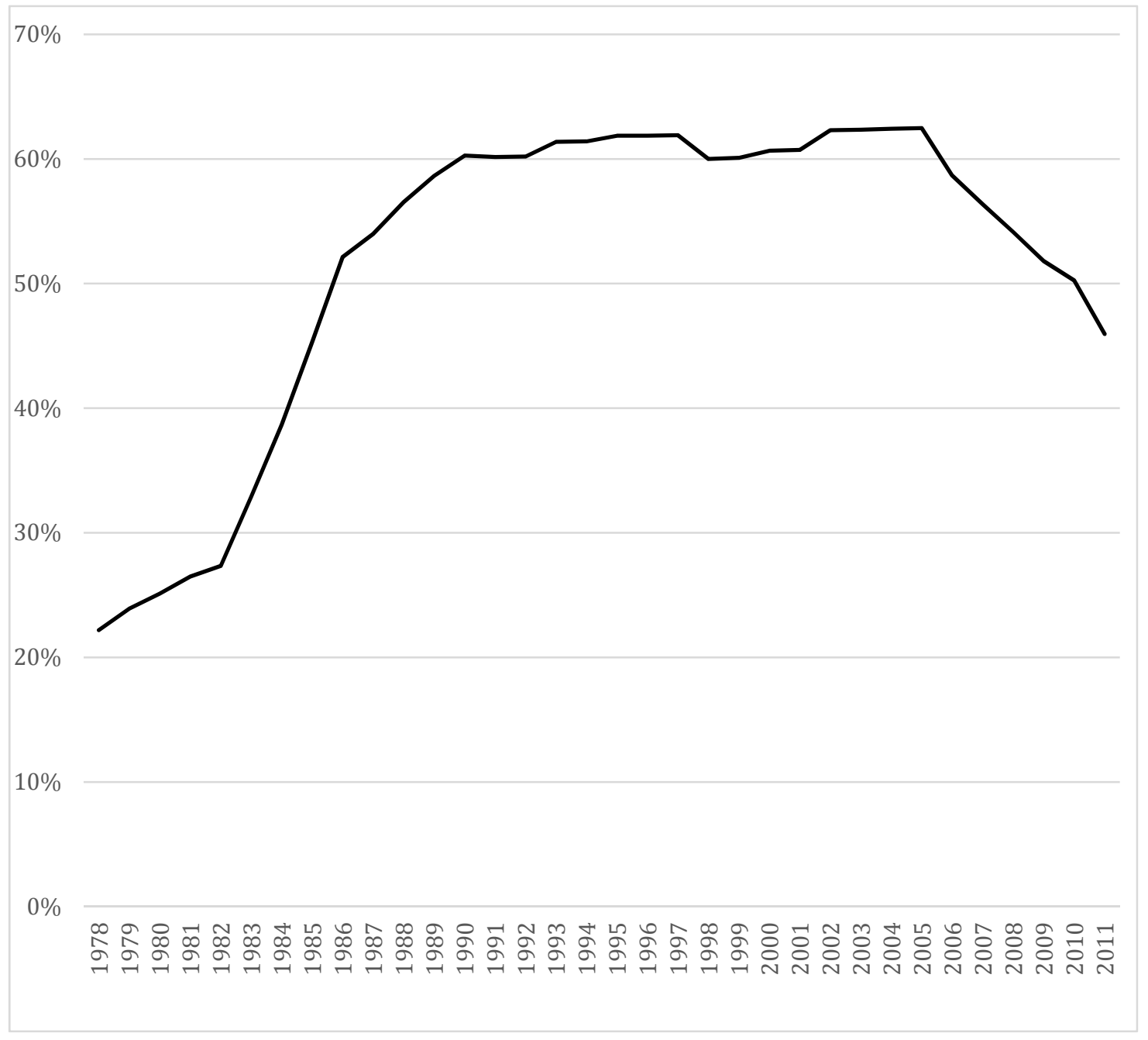


FIGURE 2:

COHORT ANALYSIS FOR STAGGERING UP AND DE-STAGGERING

Figure 2 documents the percentage of firms with a staggered board each year for six cohorts of firms: (i) firms with a staggered board in 1978 ("SB in 1978"), (ii) firms without a staggered board in 1978 ("No SB in 1978"); (iii) firms with a staggered board in 1990 ("SB in 1990"), (iv) firms without a staggered board in 1990 ("No SB in 1990"), (v) firms with a staggered board in 2000 ("SB in 2000"), and lastly (vi) firms without a staggered board in 2000 ("No SB in 2000"). The figure shows the annual percentage with a staggered board within each cohort, as a percentage of those firms that remain in our sample that year.

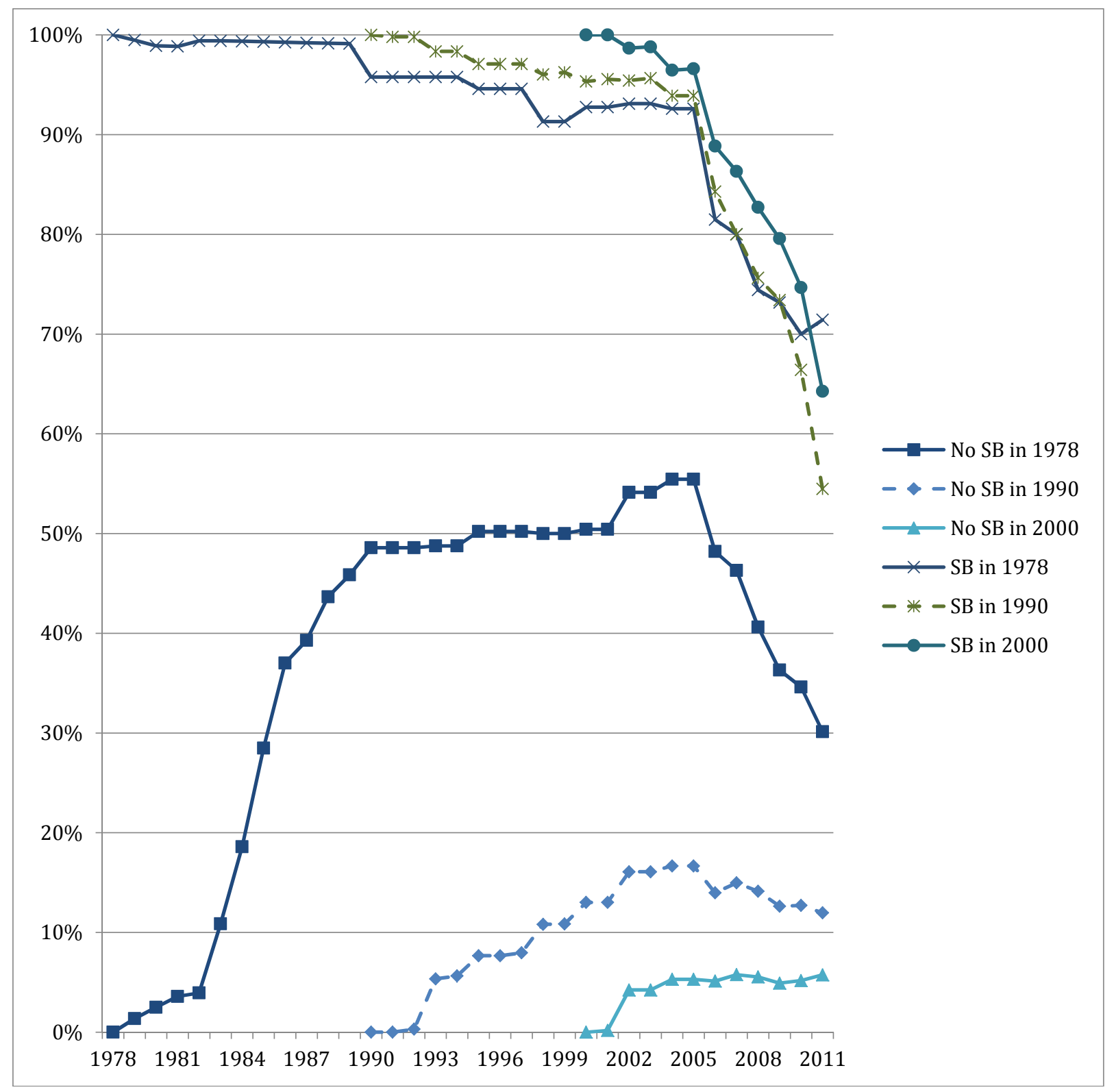


TABLE 1: Definitions of VARIABLES

Table 1 presents brief definitions of the main variables that appear in the analysis. All continuous variables are winsorized at one percent in both tails.

\section{Dependent Variables:}

Monthly Returns on long (short) portfolio "Gm12"

Monthly Returns on long (short) porffolio "12m12"

Monthly Returns on long (short) porffolio "12m24"

Tobin's $Q$

\begin{tabular}{|c|}
\hline Independent Variables: \\
\hline$C A P X / A^{2} \operatorname{sets}_{[t]}$ \\
\hline Delaware Incorporation $_{[t]}$ \\
\hline G-Index (minus staggered board) \\
\hline Insider Ownership $[t]$ \\
\hline $\operatorname{Ln}(\text { Age })_{[t]}$ \\
\hline $\operatorname{Ln}\left(\right.$ Assets) ${ }_{[t]}$ \\
\hline $\operatorname{Re}^{2} D /$ Sales $_{[t]}$ \\
\hline $\mathrm{RO} A_{[t]}$ \\
\hline Staggered Board $_{[t]}$ \\
\hline
\end{tabular}

Defined as the monthly return of a portfolio created by stocks that stagger up (down) their boards. Portfolio is created by including all stocks of firms that have (de)staggered their board for 12 months, starting 6 months before the fiscal year-end date of the year in which the company has reported its board being (de-)staggered for the first time. Returns are either equally or value weighted.

Defined as a long (short) portfolio created by including all stocks of firms that have (de)staggered their board for 12 months, starting 12 months before the fiscal year-end date of the year in which the company has reported its board being (de-)staggered.

Defined as a long (short) portfolio created by including all stocks of firms that have (de)staggered their board for 24 months, starting 12 months before the fiscal year-end date of the year in which the company has reported its board being (de-)staggered.

Defined as the Market value of assets (i.e., Total Assets - Book Equity + Market Equity) divided by the book value of assets. Calculation follows Fama and French (1992). Source of data is Compustat annual data file.

\section{Capital Expenditure $[t] /$ Total Assets $[t]$.}

Indicator variable if the company is incorporated in Delaware in year t.

Sum of 23 (i.e., 24 excluding staggered board) governance provisions indicators in the corporate charter or bylaws introduced by Gompers, Ishii, and Metrick (2003).

The insider ownership in year $t$ is the percentage of shares owned by insiders from all shares. Collected from Compact Disclosure for 1986-2006. We supplement these data with the ownership by the top management team from ExecuComp for 2007-2011. From ExecuComp, we use the total shares owned by the top five officers of the firm.

Natural logarithm of firm age. The age is calculated as the difference in year $\mathrm{t}$ and the first year the company appeared in the CRSP database.

Natural logarithm of total book assets in year $\mathrm{t}$.

$\mathrm{R} \& \mathrm{D}_{[t]} /$ Sales $[t]$.

EBITDA $_{[t]} /$ Total Assets $[t]$.

Indicator variable equal to one (zero otherwise) if the board is staggered in year t. Data are obtain from Cremers and Ferrell (2013) 
for 1978-1989, and from Risk Metrics, SharkRepellent.net and hand collection for 1990-2011.

\begin{tabular}{l}
\hline Interacted Variables: \\
CEO Delta $[t]$ \\
CEO Total Compensation $[t]$ \\
CEO Vega $[t]$ \\
CEO-Board Chairman Duality $[t]$ \\
Firm Size $[t]$ \\
Governance Index $[t]$ \\
Intangible Assets / Total Assets $[t]]$ \\
RéD/ Sales $[t]$ \\
Ranked Patent Citation Count $[t]$ \\
\hline
\end{tabular}

Percent change in the value of the Chief Executive Officer (i.e., CEO) option portfolio in year $\mathrm{t}$ for a one percent increase in stock price. We calculate it following Core and Guay (2002). Data are available from ExecuComp for 1992-2010.

CEO's Total Compensation (Salary + Bonus + Other Annual + Restricted Stock Grants + LTIP Payouts + All Other + Value of Option Grants). The source of the data is the variable TDC1 in ExecuComp data file. Available for 1992-2011.

Percent change in the value of the CEO option portfolio for a one percent increase in the volatility of the returns on the underlying stock. We calculate it following Core and Guay (2002). Data are available from ExecuComp for 1992-2010.

Indicator variable equal to one if the chairman of the board is also the CEO in year t. Source of the data is BoardEx data file and Risk Metrics (formerly IRRC) data file for 1996-2011.

Ln (Sales) in year t.

Defined above. Source is Gompers, Ishii and Metrick (2003).

(Total Assets $_{[t]}$ - Net PP\&E $[t]$ / Total Assets $[t]$.

Defined above. Source is Compustat.

Annually ranked patent citation count. Data are available for 19782003. Citations are calculated following Hall, Jaffe, and Trajtenberg (2001). Source is the NBER U.S. Patent Citations data file. 
TABLE 2: DescriptiVE STATISTICS FOR MAIN DEPENDENT AND INDEPENDENT VARIABLES.

Table 2 presents sample descriptive statistics for the main dependent and independent variables as well as the interacted variables.

\begin{tabular}{l} 
Dependent Variables: \\
\hline$Q_{[t]}$ \\
$\Delta Q_{[t, t+1]}$ \\
$\Delta Q_{[t, t+2]}$ \\
$\Delta Q_{[t, t+3]}$ \\
$\Delta Q_{[t, t+4]}$ \\
$\Delta Q_{[t, t+5]}$ \\
\hline
\end{tabular}

\begin{tabular}{cccccc} 
Mean & Median & St. Dev. & Min & Max & Obs. \\
\hline \multicolumn{7}{c}{} & & & & \\
\hline 1.581 & 1.282 & 0.867 & 0.725 & 4.660 & 31,574 \\
-0.011 & 0.006 & 0.500 & -5.298 & 4.734 & 28,464 \\
-0.018 & 0.007 & 0.638 & -5.502 & 4.941 & 26,310 \\
-0.019 & 0.012 & 0.722 & -5.500 & 4.862 & 24,273 \\
-0.017 & 0.013 & 0.771 & -5.134 & 4.895 & 22,350 \\
-0.035 & 0.004 & 0.812 & -5.427 & 4.907 & 20,558 \\
\hline \multicolumn{7}{c}{} & & & & \\
\hline Mean & Median & St. Dev. & Min & Max & Obs. \\
\hline 0.06 & 0.05 & 0.05 & 0 & 0.20 & 31,574 \\
0.55 & 1 & 0.50 & 0 & 1 & 31,574 \\
7.68 & 8.00 & 3.20 & 1 & 18.00 & 23,525 \\
0.07 & 0.03 & 0.10 & 0 & 1 & 21,216 \\
2.87 & 3.00 & 0.98 & 0 & 4.45 & 27,754 \\
7.29 & 7.17 & 1.56 & 4.55 & 11.05 & 31,574 \\
0.03 & 0 & 0.06 & 0 & 0.23 & 31,574 \\
0.14 & 0.14 & 0.08 & -0.05 & 0.32 & 31,574 \\
0.53 & 1 & 0.50 & 0 & 1 & 31,574 \\
\hline
\end{tabular}

\begin{tabular}{|c|}
\hline Independent Variables: \\
\hline$C A P X /$ Assets $[t]$ \\
\hline Delaware Incorporation $_{[t]}$ \\
\hline G-Index (minus staggered board) $[t]$ \\
\hline Insider Ownership $[t]$ \\
\hline $\operatorname{Ln}(\text { Age })_{[t]}$ \\
\hline $\operatorname{Ln}($ Assets) $[t]$ \\
\hline R\&D/ Sales $[t]$ \\
\hline $\mathrm{RO} A_{[t]}$ \\
\hline Staggered Board $[t]_{1}$ \\
\hline Interacted Variables: ${ }^{27}$ \\
\hline
\end{tabular}

\begin{tabular}{llllll}
\hline Mean & Median & St. Dev. & Min & Max & Obs. \\
\hline
\end{tabular}

ReD/Sales $\left[t_{]}\right.$

$\begin{array}{cccccc}0.003 & -0.025 & 0.0552 & -0.025 & 0.205 & 31,574 \\ -0.039 & 0.116 & 0.4665 & -1.663 & 0.448 & 31,337 \\ 0.007 & -0.023 & 0.2171 & -0.258 & 0.678 & 15,338 \\ 0.022 & -0.056 & 1.4713 & -3.309 & 3.739 & 31,558 \\ 0.023 & \theta & 0.1512 & \theta & \mathbb{4} & 31,574\end{array}$

CEO-Board Chairman Duality $[t]$
G-Index (minus staggered board) $[t]$
CEO Delta $[t]$
CEO Vega
CEO Total Compensation $[t]$

Intangible Assets/ Total Assets[t]

Ranked Patent Citation Count $[t]$

Firm Size $[t]$

High

(t)

$\begin{array}{cccccc}0.577 & 1 & 0.4941 & 0 & 1 & 10,356 \\ 0.103 & 0.428 & 3.1986 & -6.572 & 10.428 & 23,525 \\ -0.056 & -0.627 & 1.9854 & -0.855 & 15.284 & 17,573 \\ -0.002 & -0.101 & 0.2725 & -0.178 & 1.485 & 15,983 \\ 0.0004 & -0.054 & 0.8762 & -2.573 & 4.439 & 17,965\end{array}$

${ }^{27}$ All continuous variables that are used in interaction analysis are demeaned. Descriptive statistics shown above are for the demeaned variables within the samples used in the corresponding regressions. 


\section{TABLE 3: Firm VALUE AND STAGgERED BOARDS}

Table 3 shows a replication of Bebchuk and Cohen (2005) with two different sets of control variables and across different time periods. Columns (1)-(4) include the following control variables: Staggered Board $[t-1], L n$

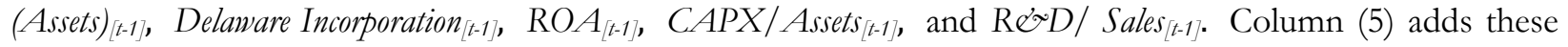
control variables: G-Index $[t-1], L n(G-I n d e x)_{[t-1]}, L n$ (Firm Age $)_{[-1]}$, Insider Ownership ${ }_{[-1-1]}$, and Insider Ownership ${ }^{2}[t-1]$. The analysis includes the following sub-periods: 1978-2011, 1978-1989, 1990-2000, 2001-2011, and 19952002. Estimation is using pooled panel Tobin's $Q_{[t]}$ regressions where year and industry fixed effects are always included. All control variables are defined in Table 1. Statistical significance of the coefficients is indicated at the $1 \%, 5 \%$, and $10 \%$ levels by ${ }^{* * *},{ }^{* *}$, and ${ }^{*}$, respectively, in two tailed tests, based on robust standard errors clustered by firm. For the key independent variable — Staggered Board $[[-1]$ — we show two separate standard errors: "(.)" reflects robust standard errors clustered at the firm level; "[.]" reflects robust standard errors that are not clustered. 
TABle 3: Firm VAlue AND STAGgERED BOARDS (CONTINUED)

\begin{tabular}{|c|c|c|c|c|c|}
\hline Dep. Variable is $Q_{[t]}$ & $(1)$ & $(2)$ & $(3)$ & (4) & $(5)$ \\
\hline Period: & $\begin{array}{c}1978- \\
2011 \\
\end{array}$ & $\begin{array}{c}1978- \\
1989 \\
\end{array}$ & $\begin{array}{c}1990- \\
2000 \\
\end{array}$ & $\begin{array}{l}2001- \\
2011 \\
\end{array}$ & $\begin{array}{l}1995- \\
2002 \\
\end{array}$ \\
\hline Staggered Board $[-1]]$ & $-0.041^{* *}$ & -0.009 & $-0.073^{* *}$ & -0.026 & -0.045 \\
\hline (firm cluster) & (2.39) & $(0.51)$ & $(2.51)$ & $(1.07)$ & $(1.26)$ \\
\hline [no cluster] & {$[5.0]$} & {$[0.96]$} & {$[4.32]$} & {$[1.96]$} & {$[1.96]$} \\
\hline G-Index $x_{[-1]}$ & - & - & - & - & $\begin{array}{c}-0.087^{* *} \\
(2.39)\end{array}$ \\
\hline $\operatorname{Ln}(G-I n d e x)_{[t-1]}$ & - & - & - & - & $\begin{array}{c}0.775^{* *} \\
(2.30)\end{array}$ \\
\hline Ln (Assets) ${ }_{[-1]}$ & $\begin{array}{c}-0.027^{* * *} \\
(3.73)\end{array}$ & $\begin{array}{c}-0.027^{* * *} \\
(3.33)\end{array}$ & $\begin{array}{c}-0.006 \\
(0.44)\end{array}$ & $\begin{array}{c}-0.042^{* * *} \\
(4.11)\end{array}$ & $\begin{array}{c}0.052^{* * *} \\
(3.25)\end{array}$ \\
\hline Ln (Firm Age) ${ }_{[t-1]}$ & - & - & - & - & $\begin{array}{l}-0.057 \\
(1.52)\end{array}$ \\
\hline Delaware Incorporation $_{[t-1]}$ & $\begin{array}{l}0.014 \\
(0.77)\end{array}$ & $\begin{array}{l}0.026 \\
(1.26)\end{array}$ & $\begin{array}{l}0.016 \\
(0.49)\end{array}$ & $\begin{array}{l}0.008 \\
(0.30)\end{array}$ & $\begin{array}{l}-0.007 \\
(0.19)\end{array}$ \\
\hline Insider Ownership ${ }_{[t-1]}$ & - & - & - & - & $\begin{array}{l}0.292 \\
(0.88)\end{array}$ \\
\hline Insider Ownershipp ${ }^{2}[-1]$ & - & - & - & - & $\begin{array}{c}-0.102 \\
(0.21)\end{array}$ \\
\hline $\mathrm{RO} A_{[t-1]}$ & $\begin{array}{l}5.076^{* * *} \\
(32.74)\end{array}$ & $\begin{array}{l}2.70^{* * *} \\
(15.97)\end{array}$ & $\begin{array}{l}5.86^{* * *} \\
(22.76)\end{array}$ & $\begin{array}{l}5.304^{* * *} \\
(24.06)\end{array}$ & $\begin{array}{l}5.925^{* * *} \\
(19.07)\end{array}$ \\
\hline$C A P X / A \operatorname{ssets}_{[t-1]}$ & $\begin{array}{l}-0.263 \\
(1.14)\end{array}$ & $\begin{array}{l}-0.251 \\
(1.23)\end{array}$ & $\begin{array}{l}-0.522 \\
(1.22)\end{array}$ & $\begin{array}{l}0.228 \\
(0.58)\end{array}$ & $\begin{array}{c}-1.038^{* *} \\
(2.14)\end{array}$ \\
\hline R\&D/Sales $[t-1]$ & $\begin{array}{l}4.23^{* * *} \\
(12.01) \\
\end{array}$ & $\begin{array}{c}4.669^{* * *} \\
(5.19)\end{array}$ & $\begin{array}{c}6.162^{* * *} \\
(10.31)\end{array}$ & $\begin{array}{c}3.819^{* * *} \\
(9.32)\end{array}$ & $\begin{array}{c}5.477^{* * *} \\
(7.15) \\
\end{array}$ \\
\hline $\mathrm{N}$ & 31,574 & 8,500 & 9,617 & 13,457 & 5,253 \\
\hline Adjusted R-Squared & 0.50 & 0.49 & 0.57 & 0.49 & 0.61 \\
\hline Year Effect & Yes & Yes & Yes & Yes & Yes \\
\hline Firm Effect & No & No & No & No & No \\
\hline Industry Effect & Yes & Yes & Yes & Yes & Yes \\
\hline \# of firms in regression & 3,023 & 1,079 & 1,420 & 2,116 & 992 \\
\hline Clustering & Firm & Firm & Firm & Firm & Firm \\
\hline
\end{tabular}




\section{TABLE 4: FIRM VALUE AND STAGGERED BOARDS - CONTROLLING FOR FIRM FIXED EFFECTS}

Table 4 shows a replication of Bebchuk and Cohen (2005) with two different sets of control variables and across different time periods. Columns (1)-(4) include the following control variables: Staggered Board $[t-1], \mathrm{Ln}$

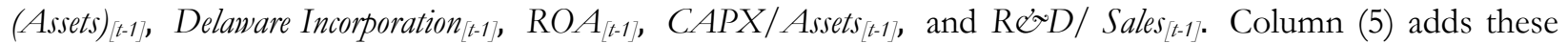

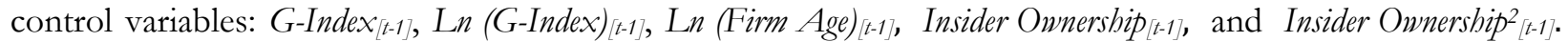
The analysis includes the following sub-periods: 1978-2011, 1978-1989, 1990-2000, 2001-2011, and 19952002. Estimation is using pooled panel Tobin's $Q_{t t}$ regressions. We include year and firm fixed effects. All control variables are defined in Table 1. Statistical significance of the coefficients is indicated at the 1\%, 5\%, and 10\% levels by ${ }^{* * *},{ }^{*}$, and *, respectively, based on robust standard errors clustered by firm. For the key

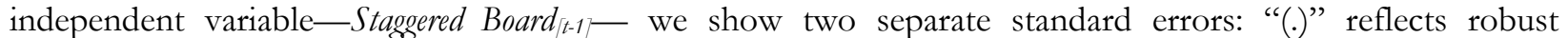
standard errors clustered at the firm level; "[.]" reflects robust standard errors that are not clustered.

\begin{tabular}{|c|c|c|c|c|c|}
\hline Dep. Variable is $Q_{[t]}$ & (1) & (2) & (3) & (4) & (5) \\
\hline Period: & $\begin{array}{l}1978- \\
2011 \\
\end{array}$ & $\begin{array}{c}1978- \\
1989 \\
\end{array}$ & $\begin{array}{l}1990- \\
2000 \\
\end{array}$ & $\begin{array}{l}2001- \\
2011 \\
\end{array}$ & $\begin{array}{l}1995- \\
2002\end{array}$ \\
\hline \multicolumn{6}{|l|}{ Variables } \\
\hline \multirow{3}{*}{ Staggered Board $_{[t-1]}$} & $0.059^{* *}$ & 0.034 & 0.009 & $0.083^{* *}$ & $0.119 *$ \\
\hline & (2.11) & $(1.26)$ & $(0.12)$ & (2.19) & $(1.81)$ \\
\hline & {$[4.65]$} & {$[2.35]$} & {$[0.19]$} & {$[3.44]$} & {$[2.13]$} \\
\hline \multirow[t]{2}{*}{ G-Index $[t-1]$} & - & - & - & - & -0.006 \\
\hline & & & & & $(0.15)$ \\
\hline \multirow[t]{2}{*}{$\operatorname{Ln}(G-I n d e x)_{[t-1]}$} & - & - & - & - & 0.016 \\
\hline & & & & & $(0.04)$ \\
\hline \multirow[t]{2}{*}{$\operatorname{Ln}(\text { Assets })_{[t-1]}$} & $-0.215^{* * *}$ & $-0.13^{* * *}$ & $-0.174^{* * *}$ & $-0.353^{* * *}$ & $-0.396^{* * *}$ \\
\hline & $(12.0)$ & $(4.56)$ & $(4.64)$ & $(11.07)$ & $(8.10)$ \\
\hline \multirow[t]{2}{*}{$\operatorname{Ln}(\text { Firm Age })_{[t-1]}$} & - & - & - & - & 0.318 \\
\hline & & & & & $(1.53)$ \\
\hline \multirow[t]{2}{*}{ Insider Ownership $[t-1]$} & - & - & - & - & 0.564 \\
\hline & & & & & $(1.27)$ \\
\hline \multirow[t]{2}{*}{ Insider Ownership ${ }^{2}[t-1]$} & - & - & - & - & -0.746 \\
\hline & & & & & $(1.06)$ \\
\hline \multirow[t]{2}{*}{$R O A_{[t-1]}$} & $2.942^{* * *}$ & $1.317^{* * *}$ & $2.801^{* * *}$ & $1.70^{* * *}$ & $2.065^{* * *}$ \\
\hline & $(20.27)$ & $(10.51)$ & $(11.41)$ & $(8.37)$ & $(7.72)$ \\
\hline \multirow[t]{2}{*}{$C A P X / A_{s s e t s[t-1]}$} & 0.103 & 0.133 & $-0.68^{* *}$ & -0.071 & $-0.916^{* *}$ \\
\hline & $(0.61)$ & $(0.8)$ & $(2.33)$ & $(0.25)$ & $(2.21)$ \\
\hline \multirow[t]{2}{*}{ ReD/Sales $[t-1]$} & $1.453^{* * *}$ & 2.035 & $3.283^{* * *}$ & 0.561 & 0.411 \\
\hline & $(2.73)$ & $(1.27)$ & $(3.43)$ & $(0.95)$ & $(0.34)$ \\
\hline
\end{tabular}

(Continued on next page) 
(Table 4 continued)

\begin{tabular}{lccccc}
\hline $\mathrm{N}$ & 31,574 & 8,500 & 9,617 & 13,457 & 5,253 \\
Adjusted R-Squared & 0.714 & 0.697 & 0.765 & 0.772 & 0.796 \\
Year Effect & Yes & Yes & Yes & Yes & Yes \\
Firm Effect & Yes & Yes & Yes & Yes & Yes \\
\# of firms in regression & 3,023 & 1,079 & 1,420 & 2,116 & 992 \\
Clustering & Firm & Firm & Firm & Firm & Firm \\
\hline
\end{tabular}


TABLE 5: FiRM VALUE AND STAGGERED BOARDS- FIRST DIFFERENCE REGRESSIONS.

\section{Panel A. Future Changes in Q vs. Past Changes in Control Variables}

Table 5, Panel A presents pooled panel first difference regressions with the dependent variable being the change in $\mathrm{Q}$ from $\mathrm{t}$ to $\mathrm{t}+1$ in column (1) (i.e., $\Delta \mathrm{Q}_{[\mathrm{t}, \mathrm{t}+1]}$ ), the change in $\mathrm{Q}$ from $\mathrm{t}$ to $\mathrm{t}+2$ in column (2) (i.e., $\Delta$ $\mathrm{Q}_{[\mathrm{t}, \mathrm{t}+2]}$ ), the change in $\mathrm{Q}$ from $\mathrm{t}$ to $\mathrm{t}+3$ in column (3) (i.e., $\Delta \mathrm{Q}_{[\mathrm{t}, \mathrm{t}+3]}$ ), the change in $\mathrm{Q}$ from $\mathrm{t}$ to $\mathrm{t}+4$ in column (4) (i.e., $\Delta \mathrm{Q}_{[\mathrm{t}, \mathrm{t}+4]}$ ), and the change in $\mathrm{Q}$ from $\mathrm{t}$ to $\mathrm{t}+5$ in column (5) (i.e., $\Delta \mathrm{Q}_{[\mathrm{t}, \mathrm{t}+5]}$ ). As independent

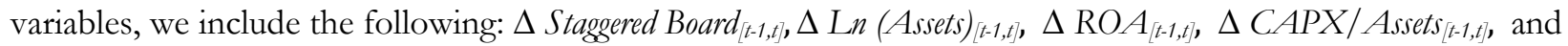
$\Delta R \Theta D /$ Sales $[t-1, t]$. Sample period is 1978-2011, but varies per model due to availability of lagged data and is reported for each model. Standard errors are clustered at the firm level. T-statistics (in their absolute value) of the regression coefficients are shown in parentheses below the coefficient estimates. Statistical significance of the coefficients is indicated at the $1 \%, 5 \%$, and $10 \%$ levels by ${ }^{* * *}$, ${ }^{* *}$, and ${ }^{*}$, respectively. All control variables are defined in Table 1. Our sample for Column (1) includes 351 cases of staggering up and 307 cases of staggering down. The number of firms per regression model is noted in the table.

\begin{tabular}{|c|c|c|c|c|c|}
\hline Dep. Variables: & $\Delta \mathrm{Q}_{[\mathrm{t}, \mathrm{t}+1]}$ & $\Delta \mathrm{Q}_{[\mathrm{t}, \mathrm{t}+2]}$ & $\Delta \mathrm{Q}_{[\mathrm{t}, \mathrm{t}+3]}$ & $\Delta \mathrm{Q}_{[\mathrm{t}, \mathrm{t}+4]}$ & $\Delta \mathrm{Q}_{[\mathrm{t}, \mathrm{t}+5}$ \\
\hline Variables & (1) & (2) & (3) & (4) & (5) \\
\hline \multirow[t]{2}{*}{$\Delta$ Staggered Board $[t-1, t]$} & $0.03^{*}$ & $0.079^{* * *}$ & $0.123^{* * *}$ & $0.103^{* * *}$ & $0.153^{* * *}$ \\
\hline & $(1.89)$ & $(2.98)$ & $(4.26)$ & $(3.0)$ & $(4.10)$ \\
\hline \multirow[t]{2}{*}{$\Delta \operatorname{Ln}(\text { Assets })_{[t-1, t]}$} & $-0.311^{* * *}$ & $-0.546^{* * *}$ & $-0.592^{* * *}$ & $-0.607^{* * *}$ & $-0.625^{* * *}$ \\
\hline & $(14.14)$ & $(17.02)$ & $(15.74)$ & $(15.43)$ & $(13.99)$ \\
\hline \multirow[t]{2}{*}{$\Delta \mathrm{RO} A_{[t-1, t]}$} & $-0.34^{* * *}$ & $-0.857^{* * *}$ & $-1.271^{* * *}$ & $-1.55^{* * *}$ & $-1.588^{* * *}$ \\
\hline & $(3.93)$ & $(8.64)$ & $(10.74)$ & (11.63) & $(10.97)$ \\
\hline \multirow[t]{2}{*}{$\Delta C A P X / A \operatorname{ssets}_{[t-1, t]}$} & $-0.925^{* * *}$ & $-0.904^{* * *}$ & $-1.203^{* * *}$ & $-1.083^{* * *}$ & $-1.038^{* * *}$ \\
\hline & $(6.42)$ & $(5.17)$ & $(6.66)$ & $(6.12)$ & $(5.26)$ \\
\hline \multirow[t]{2}{*}{$\Delta R \otimes D /$ Sales $[-1, t]$} & 0.651 & 0.448 & 0.168 & 0.308 & -0.519 \\
\hline & $(1.51)$ & $(0.87)$ & $(0.28)$ & $(0.52)$ & $(0.68)$ \\
\hline Sample Period (vears for $t$ ) & $\begin{array}{l}1979- \\
2011\end{array}$ & $\begin{array}{l}1979- \\
2010\end{array}$ & $\begin{array}{l}1979- \\
2009\end{array}$ & $\begin{array}{l}1979- \\
2008\end{array}$ & $\begin{array}{l}1979- \\
2007\end{array}$ \\
\hline \# of firms in regression & 2792 & 2623 & 2480 & 2335 & 2128 \\
\hline $\mathrm{N}$ & 200 & 26170 & 21146 & 52025 & 20440 \\
\hline Adjusted R-Squared & 0.018 & 0.031 & 0.032 & 0.03 & 0.028 \\
\hline
\end{tabular}


TABLE 5: FiRM VALUE AND STAGGERED BOARDS- FIRST DIFFERENCE REGRESSIONS.

Panel B. Future Changes in Q vs. Past Changes in CONTRol VARIABles (INCLUding transition YEAR)

Table 5, Panel B presents pooled panel first difference regressions with the dependent variable being the change in $\mathrm{Q}$ from $\mathrm{t}-1$ to $\mathrm{t}$ in column (1) (i.e., $\left.\Delta \mathrm{Q}_{[\mathrm{t}-1, \mathrm{t}]}\right)$, the change in $\mathrm{Q}$ from $\mathrm{t}-1$ to $\mathrm{t}+1$ in column (2) (i.e., $\Delta$ $\mathrm{Q}_{[\mathrm{t}-1, \mathrm{t}+1]}$ ), the change in $\mathrm{Q}$ from $\mathrm{t}-1$ to $\mathrm{t}+2$ in column (3) (i.e., $\Delta \mathrm{Q}_{[\mathrm{t}-1, \mathrm{t}+2]}$ ), , the change in $\mathrm{Q}$ from $\mathrm{t}-1$ to $\mathrm{t}+3$ in column (4) (i.e., $\Delta \mathrm{Q}_{[\mathrm{t}-1, \mathrm{t}+3]}$ ), and the change in $\mathrm{Q}$ from $\mathrm{t}-1$ to $\mathrm{t}+4$ in column (5) (i.e., $\left.\Delta \mathrm{Q}_{[\mathrm{t}-1, \mathrm{t}+4]}\right)$. As

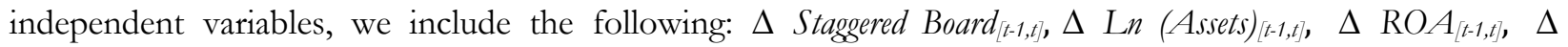
$C A P X / A s e t s_{[t-1, t]}$, and $\Delta R \Theta D /$ Sales $[t-1, t]$. Sample period is 1978-2011, but it varies per model due to availability of lagged data and is reported for each model. Standard errors are clustered at the firm level. Results are robust to an adjustment to the standard errors for autocorrelation as in Newey-West (where the adjustment includes up to sixth lags). T-statistics (in their absolute value) of the regression coefficients are shown in parentheses below the coefficient estimates. Statistical significance of the coefficients is indicated at the $1 \%, 5 \%$, and $10 \%$ levels by ${ }^{* * *},{ }^{*}$, and ${ }^{*}$, respectively. All control variables are defined in Table 1 . Our sample for Column (1) includes 341 cases of staggering up and 272 cases of staggering down. The number of firms per regression model is noted in the table.

\begin{tabular}{|c|c|c|c|c|c|}
\hline Der. Variables: & $\Delta \mathrm{Q}_{[\mathrm{t}-1, \mathrm{t}]}$ & $\Delta \mathrm{Q}_{[\mathrm{t}-1, \mathrm{t}+1]}$ & $\Delta \mathrm{Q}_{[\mathrm{t}-1, \mathrm{t}+2]}$ & $\Delta \mathrm{Q}_{[\mathrm{t}-1, \mathrm{t}+3]}$ & $\Delta \mathrm{Q}_{[\mathrm{t}-1, \mathrm{t}+4]}$ \\
\hline Variables & $(1)$ & $(2)$ & (3) & $(4)$ & $(5)$ \\
\hline \multirow[t]{2}{*}{$\Delta$ Staggered Board $[t-1, t]$} & $0.054^{* * *}$ & $0.085^{* * *}$ & $0.131^{* * *}$ & $0.18^{* * *}$ & $0.168^{* * *}$ \\
\hline & $(3.40)$ & $(3.76)$ & $(4.35)$ & $(5.65)$ & $(4.39)$ \\
\hline \multirow[t]{2}{*}{$\Delta \operatorname{Assets}_{[t-1, t]}$} & $-0.336^{* * *}$ & $-0.638^{* * *}$ & $-0.853^{* * *}$ & $-0.899^{* * *}$ & $-0.901^{* * *}$ \\
\hline & $(12.42)$ & $(18.79)$ & $(20.61)$ & $(20.35)$ & $(19.17)$ \\
\hline \multirow[t]{2}{*}{$\Delta R O A_{[t-1, t]}$} & $2.281^{* * *}$ & $1.996^{* * *}$ & $1.562^{* * *}$ & $1.183^{* * *}$ & $1.167^{* * *}$ \\
\hline & (19.93) & $(14.61)$ & $(11.80)$ & $(8.56)$ & $(7.80)$ \\
\hline \multirow[t]{2}{*}{$\Delta C A P X / A \operatorname{ssets}_{[t-1, t]}$} & $-0.355^{* *}$ & $-1.282^{* * *}$ & $-1.256^{* * *}$ & $-1.597^{* * *}$ & $-1.355^{* * *}$ \\
\hline & $(2.33)$ & $(7.62)$ & $(7.25)$ & $(8.6)$ & $(6.69)$ \\
\hline \multirow[t]{2}{*}{$\Delta$ R\&D/Sales $[t-1, t]$} & $-0.964^{* *}$ & -0.508 & -0.60 & -0.924 & -0.712 \\
\hline & $(2.05)$ & $(1.13)$ & $(1.05)$ & $(1.39)$ & $(0.92)$ \\
\hline Sample Period (years) & $\begin{array}{l}1979- \\
2012 \\
\end{array}$ & $\begin{array}{c}1979- \\
2011 \\
\end{array}$ & $\begin{array}{l}1979- \\
2010\end{array}$ & $\begin{array}{l}1979- \\
2009 \\
\end{array}$ & $\begin{array}{l}1979- \\
2008 \\
\end{array}$ \\
\hline \# of firms in regression & 2,908 & 2,788 & 2,618 & 2,475 & 2,329 \\
\hline $\mathrm{N}$ & 29,387 & 28,220 & 26,077 & 24,050 & 22,134 \\
\hline Adjusted R-Squared & 0.061 & 0.06 & 0.064 & 0.059 & 0.052 \\
\hline
\end{tabular}




\section{Table 6, Panels A and B: Portfolio Analysis}

Table 6 presents the analysis of monthly portfolio returns for firms that have staggered up (in the 'long' portfolio) and firms that have de-staggerred (in the 'short' portfolio). Presented are the equally weighted (value weighted) returns in Panel A (Panel B) for the long portfolio minus the short portfolio around board staggering and de-staggering event in our sample of firms during the time period 1978-2011. The long (short) portfolios are composed every month as follows. For portfolio " $6 \mathrm{~m} 12$ ", we include all stocks of firms that have (de-)staggered their boards starting 6 months before the fiscal year-end date of the year in which the firm has reported its board being (de-)staggered for the first time, and hold these stocks for 12 months. For portfolio " $12 \mathrm{~m} 12$ ", we include all stocks of firms that have (de-)staggered their boards starting 12 months before the fiscal year-end date of the year in which the firm has reported its board being (de-)staggered for

the first time, and again hold these stocks for 12 months. For portfolio " $12 \mathrm{~m} 24$ ", we include all stocks of firms that have (de-)staggered their boards starting 12 months before the fiscal year-end date of the year in which the firm has reported its board being (de-)staggered for the first time, and hold these stocks for 24 months. We use three models: the four factor Carhart (1997) model (i.e., Momentum, HML, SMB, and market return), the three factor Fama-French model (i.e., HML, SMB, and market return), and the market model (i.e., CAPM). For each model, we present the returns to the (i) long portfolio, (ii) short portfolio, and (iii) long minus short portfolio. The absolute values of the t-statistics are based on robust standard errors and are presented in parentheses below the coefficients. The annualized alphas to each portfolio are in percentages based on monthly returns. Statistical significance of the coefficients is indicated at the $1 \%, 5 \%$, and $10 \%$ levels by ${ }^{* * *},{ }^{* *}$, and ${ }^{*}$, respectively. The average number of stocks in the long and short portfolios (averaged across all months) is shown for the four factor model. 
Table 6, Panel A: Portfolio Analysis -Equally Weighted Returns (Continued)

\begin{tabular}{|c|c|c|c|c|c|c|c|c|c|}
\hline & & & & & \\
\hline & \multicolumn{3}{|c|}{ Four Factors Model } & \multicolumn{3}{|c|}{ Three Factors Model } & \multicolumn{3}{|c|}{ Market Factor Model } \\
\hline & Long & Short & $\begin{array}{l}\text { Long - } \\
\text { Short }\end{array}$ & Long & Short & $\begin{array}{l}\text { Long - } \\
\text { Short }\end{array}$ & Long & Short & $\begin{array}{l}\text { Long - } \\
\text { Short }\end{array}$ \\
\hline \multirow[t]{2}{*}{ Alpha (Monthly) } & $0.516^{* *}$ & 0.062 & 0.416 & $0.442^{*}$ & -0.016 & 0.447 & $0.738^{* *}$ & 0.141 & 0.479 \\
\hline & $(2.04)$ & $(0.19)$ & $(0.95)$ & $(1.72)$ & $(0.05)$ & $(1.05)$ & $(2.57)$ & $(0.43)$ & $(1.13)$ \\
\hline Alpha (Annual) & $6.37 \%$ & $0.75 \%$ & $5.11 \%$ & $5.43 \%$ & $-0.19 \%$ & $5.50 \%$ & $9.22 \%$ & $1.71 \%$ & $5.90 \%$ \\
\hline \multicolumn{10}{|l|}{ Average Monthly } \\
\hline Number of Firms & 13 & 15.2 & - & 13 & 15.2 & - & 13 & 15.2 & - \\
\hline$N$ & 321 & 224 & 211 & 321 & 224 & 211 & 321 & 224 & 211 \\
\hline Adj. R-squared & 0.613 & 0.587 & 0.010 & 0.611 & 0.571 & 0.011 & 0.532 & 0.526 & 0 \\
\hline \multirow{3}{*}{$\frac{\text { Portfolio }}{" 12 m 12 "}$} & \multirow{2}{*}{\multicolumn{3}{|c|}{ Four Factors Model }} & \multirow{2}{*}{\multicolumn{3}{|c|}{ Three Factors Model }} & \multirow{2}{*}{\multicolumn{3}{|c|}{ Market Factor Model }} \\
\hline & & & & & & & & & \\
\hline & Long & Short & $\begin{array}{l}\text { Long - } \\
\text { Short }\end{array}$ & Long & Short & $\begin{array}{c}\text { Long - } \\
\text { Short }\end{array}$ & Long & Short & $\begin{array}{l}\text { Long - } \\
\text { Short }\end{array}$ \\
\hline \multirow[t]{2}{*}{ Alpha (Montbly) } & 0.529 & -0.293 & $1.235^{* *}$ & 0.388 & -0.425 & $1.296^{* *}$ & $0.581^{*}$ & -0.256 & $1.266^{* * *}$ \\
\hline & $(1.54)$ & $(1.08)$ & $(2.24)$ & (1.13) & $(1.59)$ & $(2.47)$ & $(1.85)$ & $(0.93)$ & $(2.65)$ \\
\hline Alpha (Annual) & $6.54 \%$ & $-3.46 \%$ & $15.87 \%$ & $4.76 \%$ & $-4.98 \%$ & $16.71 \%$ & $7.20 \%$ & $-3.03 \%$ & $16.30 \%$ \\
\hline \multicolumn{10}{|l|}{ Average Monthly } \\
\hline Number of Firms & 12.8 & 16.1 & - & 12.8 & 16.1 & - & 12.8 & 16.1 & - \\
\hline$N$ & 319 & 237 & 216 & 319 & 237 & 216 & 319 & 237 & 216 \\
\hline Adj. R-squared & 0.466 & 0.62 & 0.002 & 0.459 & 0.606 & 0.005 & 0.416 & 0.575 & 0.011 \\
\hline \multirow[t]{3}{*}{$\frac{\text { Portfolio }}{\text { "12m24" }}$} & \multicolumn{3}{|c|}{ Four Factors Model } & \multicolumn{3}{|c|}{ Three Factors Model } & \multicolumn{3}{|c|}{ Market Factor Model } \\
\hline & & & Long - & & & Long - & & & Long - \\
\hline & Long & Short & Short & Long & Short & Short & Long & Short & Short \\
\hline \multirow[t]{2}{*}{ Alpha (Monthly) } & $0.401^{* *}$ & 0.039 & 0.419 & $0.292^{*}$ & -0.067 & 0.407 & $0.525^{* * *}$ & 0.039 & $0.461^{*}$ \\
\hline & $(2.30)$ & $(0.17)$ & $(1.44)$ & $(1.65)$ & $(0.31)$ & $(1.45)$ & $(2.7)$ & $(0.18)$ & $(1.68)$ \\
\hline Alpha (Annual) & $4.92 \%$ & $0.47 \%$ & $5.15 \%$ & $3.56 \%$ & $-0.80 \%$ & $4.99 \%$ & $6.49 \%$ & $0.47 \%$ & $5.67 \%$ \\
\hline \multicolumn{10}{|l|}{ Average Monthly } \\
\hline Number of Firms & 23.7 & 22.5 & - & 23.7 & 22.5 & - & 23.7 & 22.5 & - \\
\hline$N$ & 388 & 350 & 349 & 388 & 350 & 349 & 388 & 350 & 349 \\
\hline Adj. R-squared & 0.679 & 0.623 & 0.001 & 0.671 & 0.617 & 0.004 & 0.603 & 0.593 & 0 \\
\hline
\end{tabular}


Table 6, Panel B: Portfolio Analysis -Value Weighted Returns (Continued)

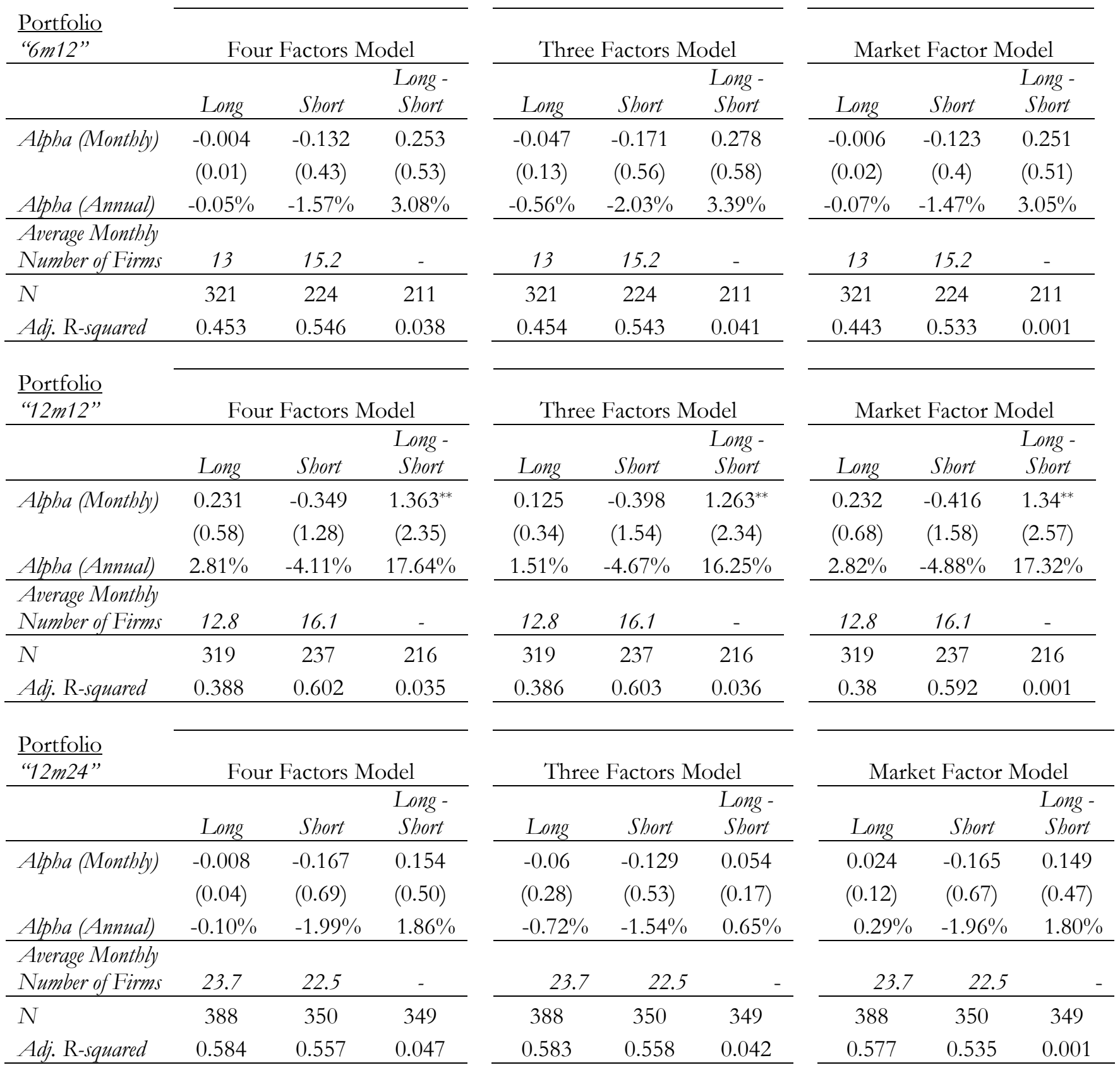




\section{TABle 7: Firm VALUE AND STAgGERED BOARDS: REVERSE CAUSALITY TESTS}

Table 7 presents reverse causality regressions to explain the adoption (in Panel A) and removal (in Panel B) of a staggered board as a function of the valuation of the firm (as captured by $Q_{(t)}$ ) plus other characteristics. The sample for Panel B (A) includes all firms that do (not) have a staggered board up until (and including) the year in which they remove (adopt) the staggered board if there is any such change, and are dropped from the sample afterwards. Each panel shows three models. Column (1) uses a random effects Probit model, with robust standard errors clustered by firm and reporting marginal effects. Column (2) uses the Cox proportional hazard model (see Greene, 2000, page 950) and reports the hazard ratio using robust standard errors clustered at the firm level (after standardizing the continuous variables to have zero mean and unit variance). Dual-class stocks are removed from the sample. The economic effect in Column (1) is estimated as the marginal effect times one standard deviation in $Q_{[-1]}$ divided by the average unconditional probability in the sample for that model. In Column (2) the economic effect is estimated as the difference between the hazard ratio and one and is recorded as a percentage. Statistical significance of the coefficients is indicated at the 1\%, 5\%, and 10\% levels by ${ }^{* * *},{ }^{* *}$, and ${ }^{*}$, respectively. T-statistics (in their absolute value) are shown in parentheses below the coefficient estimates. All control variables are defined in Table 1. The sample in the table refers to the time period 1978-2011. 
TABle 7: Firm VAlue and Staggered BoARds: REVERSE CAUSALITY TESTS (CONTINUED)

\section{Panel A. PRedict STAggering up}

Dep. Variable is: $\operatorname{Pr}(($ Stagger in period $\mathrm{t})$

\begin{tabular}{|c|}
\hline Variables \\
\hline$Q_{[-1]}$ \\
\hline $\operatorname{Ln}$ (Assets) ${ }_{[t-1]}$ \\
\hline Delaware Incorporation $[t-1]$ \\
\hline $\mathrm{RO} A_{[t-1]}$ \\
\hline Capital Expense/Assets[t-1] \\
\hline RळD/Sales $[-1]$ \\
\hline Percentage Effect (i.e., Economic Significance) \\
\hline $\mathrm{N}$ \\
\hline Pseudo R-2 \\
\hline Adjusted R-2 \\
\hline Wald Chi-2 (p-value) \\
\hline \# of firms in regression \\
\hline
\end{tabular}

\begin{tabular}{cc}
\hline $\begin{array}{c}\text { Random } \\
\text { Effects }\end{array}$ & Cox \\
Probit Model & Model \\
\hline$(1)$ & $(2)$ \\
\hline$-0.007^{* * *}$ & $0.422^{* * *}$ \\
$(3.76)$ & $(7.63)$ \\
-0.0003 & $1.11^{*}$ \\
$(0.45)$ & $(1.69)$ \\
-0.001 & $0.791^{* *}$ \\
$(0.47)$ & $(2.14)$ \\
$0.031^{*}$ & $1.473^{* * *}$ \\
$(1.66)$ & $(5.06)$ \\
$0.056^{* *}$ & $1.124^{* *}$ \\
$(2.24)$ & $(2.45)$ \\
$-0.073^{* *}$ & 0.897 \\
$(2.47)$ & $(1.55)$ \\
\hline & \\
\hline$-29.3 \%$ & $-57.8 \%$ \\
\hline 15,359 & 14,535 \\
- & 0.04 \\
- & - \\
$42.9(0.00)$ & - \\
1,784 & 1,651 \\
\hline &
\end{tabular}


TABle 7: Firm VAlue and Staggered BoARds: REVERSE CAUSALITY TESTS (CONTINUED)

\section{$\underline{\text { PANel B. PREDiCT DE-STAGgering }}$}

Dep. Variable is: $\operatorname{Pr}$ (De-stagger in period $\mathrm{t}$ )

\begin{tabular}{cc}
\hline $\begin{array}{c}\text { Random } \\
\text { Effects } \\
\text { Probit Model }\end{array}$ & $\begin{array}{c}\text { Cox } \\
\text { Model }\end{array}$ \\
\hline$(1)$ & $(2)$ \\
\hline 0.001 & 0.857 \\
$(0.74)$ & $(1.45)$ \\
$0.007^{* * *}$ & $1.83^{* * *}$ \\
$(12.74)$ & $(6.23)$ \\
0.003 & 1.019 \\
$(1.68)$ & $(0.12)$ \\
-0.019 & 1.045 \\
$(1.36)$ & $(0.42)$ \\
-0.03 & 1.029 \\
$(1.42)$ & $(0.5)$ \\
0.002 & 0.992 \\
$(0.11)$ & $(0.09)$ \\
\hline & \\
\hline$-4.8 \%$ & $-14.3 \%$ \\
\hline 17,368 & 13,462 \\
- & 0.027 \\
- & - \\
$161.6(0.00)$ & - \\
1,813 & 1,494 \\
\hline &
\end{tabular}




\section{TABle 8. Firm VAlue and Staggered BoARds: CONTROLling FOR LAGGED Q (I.E., Q[T-1]) REPLICATION OF TABLE 3}

Table 8 shows a replication of Bebchuk and Cohen (2005) with two different sets of control variables and across different time periods. Columns (1)-(4) include the following control variables: $Q_{[t-1]}$, Staggered Board $[t-1]$, Ln (Assets) $[t-1]$, Delaware Incorporation $[t-1], R O A_{[t-1]}, C A P X / A_{s_{s e t s}[t-1]}$, and ReD/ Sales $[t-1]$. Column (5) adds these control variables: G-Index $[t-1], L n(G-I n d e x)_{[t-1]}, L n$ (Firm Age) $[t-1]$, Insider Ownership $[t-1]$, and Insider Ownership ${ }^{2}[t-1]$. The analysis includes the following sub-periods: 1978-2011, 1978-1989, 1990-2000, 2001-2011, and 19952002. Estimation is using pooled panel Tobin's $Q_{[t]}$ regressions where year and industry fixed effects are always included. All control variables are defined in Table 1. Statistical significance of the coefficients is indicated at the $1 \%, 5 \%$, and $10 \%$ levels by ${ }^{* * *},{ }^{* *}$, and ${ }^{*}$, respectively, based on robust standard errors clustered by firm. For the key independent variable—Staggered Board $[t-1]$ — we show two separate standard errors: "(.)" reflects robust standard errors clustered at the firm level; "[.]" reflects robust standard errors that are not clustered. 
TABle 8. Firm VAlue and Staggered BoARds: Controlling FOR LagGed Q (I.E., Q $\left.Q_{[T-1]}\right)$ REPLICATION OF TABLE 3 (CONTINUED)

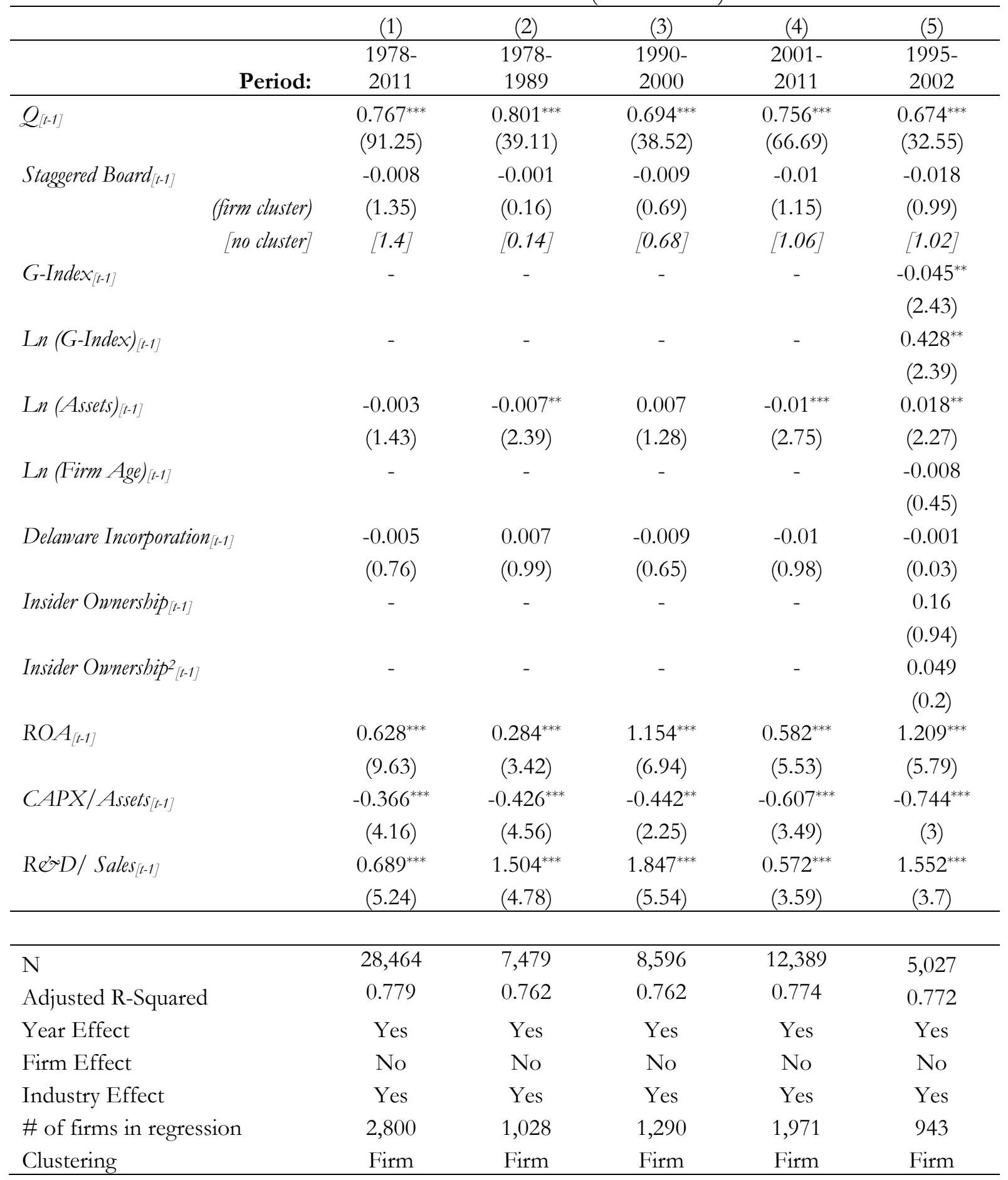


TABLE 9. Firm VALUE AND STAGgERED BOARDS

INTERACTIONS OF STAGGERED BOARD WITH INVESTMENTS AND OPERATIONAL COMPLEXITY

In Table 9 we present time-series analysis as in Table 4 that includes interactions with variables that capture investments and operational complexity. We include the following control variables: Ln (Assets) [t-1], Delaware

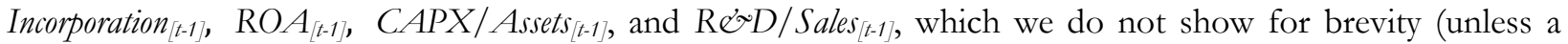
variable is being interacted with Staggered Board $[t-1]$. The interacted variables include the following: R\&D/ Sales $[t$, Intangible Assets/ Total Assets $[t]$, Ranked Patent Citation Count $[t]$, and Firm Size $[t]$. The sample period is 19782011. Individual interactions vary in their availability, as noted by the observation count and year span for each estimated model. All continuous variables in the interaction terms (R\&D/Sales $[t$, Intangible Assets/Total

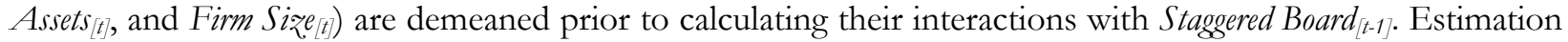
is using pooled panel Tobin's $Q_{[t]}$ regressions. We include year and firm fixed effects. All interaction and control variables are defined in Table 1. Economic significance for the interactions of the continuous interacted variables is calculated as the coefficient estimate times the standard deviation of the interacted variable, divided by the sample average for $Q_{[t]}$. Economic significance for Staggered Board $[t-1]$ is calculated as its coefficient estimate divided by average $Q_{[t]}$. Robust standard errors are clustered at the firm level. T-statistics (in their absolute value) are shown in parentheses below the coefficient estimates. Statistical significance of the coefficients is indicated at the $1 \%, 5 \%$, and $10 \%$ levels by ${ }^{* * *}$, ${ }^{* *}$, and ${ }^{*}$, respectively. 
Table 9. Firm Value And Staggered BoArds

INTERACTIONS OF STAGGERED BOARD WITH INVESTMENTS AND OPERATIONAL COMPLEXITY (CONTINUED)

\begin{tabular}{|c|c|c|c|c|c|c|c|c|}
\hline Variables & (1) & (2) & (3) & (4) & (5) & (6) & (7) & (8) \\
\hline Staggered Board $_{[t-1]}$ & $\begin{array}{c}0.071^{* *} \\
(2.44)\end{array}$ & $\begin{array}{c}0.059^{* *} \\
(2.11)\end{array}$ & $\begin{array}{c}0.073^{* *} \\
(2.44)\end{array}$ & $\begin{array}{l}0.06^{* *} \\
(2.13)\end{array}$ & $\begin{array}{l}0.027 \\
(0.68)\end{array}$ & $\begin{array}{l}0.025 \\
(0.65)\end{array}$ & $\begin{array}{l}0.037 \\
(1.39)\end{array}$ & $\begin{array}{c}0.058^{* *} \\
(2.11)\end{array}$ \\
\hline $\operatorname{R\mho \sigma D} /$ Sales $_{[t-1]}$ & $\begin{array}{l}0.395 \\
(0.56)\end{array}$ & $\begin{array}{c}1.453^{* * *} \\
(2.73)\end{array}$ & & & & & & \\
\hline Intangible Assets/ Total Assets $[$ [t-1] & & & $\begin{array}{l}0.061 \\
(1.59)\end{array}$ & $\begin{array}{c}0.119^{* * *} \\
(3.75)\end{array}$ & & & & \\
\hline Ranked Patent Citation Count $t_{[-1]}$ & & & & & $\begin{array}{l}0.036 \\
(0.39)\end{array}$ & $\begin{array}{c}0.158^{* *} \\
(2.5)\end{array}$ & & \\
\hline Firm Size $[t-1]$ & & & & & & & $\begin{array}{c}-0.024 \\
(0.88)\end{array}$ & $\begin{array}{c}-0.005 \\
(0.21)\end{array}$ \\
\hline R\&D/ Salest-1 $*$ Staggered Board $[t-1]$ & $\begin{array}{c}1.962^{* *} \\
(2.54)\end{array}$ & - & & & & & & \\
\hline Intangible Assets/ Total Assets $[t-1]$ * & & & & & & & & \\
\hline Staggered Board $[t-1]$ & & & $\begin{array}{c}0.118^{* * *} \\
(2.86)\end{array}$ & $\begin{array}{l}- \\
-\end{array}$ & & & & \\
\hline Ranked Patent Citation Count ${ }_{[t-1]}$ * & & & & & & & & \\
\hline Staggered Board $_{[t-1]}$ & & & & & $\begin{array}{c}0.229 * \\
(1.92)\end{array}$ & $\begin{array}{l}- \\
-\end{array}$ & & \\
\hline Firm Size $[t-1]$ * Staggered Board $[t-1]$ & & & & & & & $\begin{array}{c}0.037^{* *} \\
(2.34)\end{array}$ & - \\
\hline Economic Significance (Staggered B.) & $4.49 \%$ & - & $4.61 \%$ & - & $1.71 \%$ & - & $2.34 \%$ & - \\
\hline Economic Significance (Int. Variable) & $10.8 \%$ & - & $3.96 \%$ & - & $4.97 \%$ & - & $3.44 \%$ & - \\
\hline Sample Period (Years) & $\begin{array}{c}1978- \\
2011 \\
\end{array}$ & - & $\begin{array}{c}1978- \\
2011 \\
\end{array}$ & - & $\begin{array}{c}1978- \\
2003 \\
\end{array}$ & - & $\begin{array}{c}1978- \\
2011\end{array}$ & - \\
\hline$N$ & 31,574 & 31,574 & 31,337 & 31,337 & 15,338 & 15,338 & 31,558 & 31,558 \\
\hline Adjusted R-2 & 0.7149 & 0.7149 & 0.714 & 0.714 & 0.725 & 0.725 & 0.7146 & 0.7143 \\
\hline Clustering of Standard Errors & Firm & Firm & Firm & Firm & Firm & Firm & Firm & Firm \\
\hline Firm \& Year Fixed Effect & Yes & Yes & Yes & Yes & Yes & Yes & Yes & Yes \\
\hline
\end{tabular}




\section{TABLE 10. Firm VALUE AND STAgGERED BOARDS \\ INTERACTIONS OF STAGGERED BOARD WITH BOARD FEATURES AND GOVERNANCE PROVISIONS}

In Table 10 we present time-series analysis as in Table 4 that includes interactions with variables that capture board features and governance provisions. We include the following control variables: $L n$ (Assets) $[t-1]$, Delaware

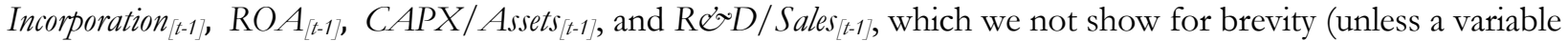
is being interacted with Staggered Board $[-1]]$. The interacted variables include the following: CEO-Board Chairman Duality $_{[t-1]}$, and G-Index $[t-1]$. The sample period is 1978-2011. Individual interactions vary in their availability, as noted by the observation count and year span for each estimated model. The G-Index $\left[t_{-1]}\right.$ is demeaned prior to calculating its interaction with Staggered Board $[t-1]$. Estimation is using pooled panel Tobin's $Q_{[t]}$ regressions. We include year and firm fixed effects. All interaction and control variables are defined in Table 1. Economic significance for the interactions of the continuous interacted variables is calculated as the coefficient estimate times the standard deviation of the interacted variable, divided by the sample average for $Q_{[t]}$. Economic significance for Staggered Board $[t-1]$ is calculated as its coefficient estimate divided by average $Q_{[t]}$. Robust standard errors are clustered at the firm level. T-statistics (in their absolute value) are shown in parentheses below the coefficient estimates. Statistical significance of the coefficients is indicated at the 1\%,5\%, and $10 \%$ levels by ${ }^{* * *}, * *$, and ${ }^{*}$, respectively. 
TABLE 10. FIRM VALUE AND STAGGERED BOARDS

INTERACTIONS OF STAGGERED BOARD WITH BOARD FEATURES AND GOVERNANCE PROVISIONS (CONTINUED)

\begin{tabular}{|c|c|c|c|c|}
\hline Variables & (1) & (2) & (3) & (4) \\
\hline Staggered Board $[t-1]$ & $\begin{array}{c}0.091^{*} \\
(1.94)\end{array}$ & $\begin{array}{c}0.133^{* * *} \\
(2.97)\end{array}$ & $\begin{array}{c}0.077^{* *} \\
(2.57)\end{array}$ & $\begin{array}{c}0.077^{* *} \\
(2.58)\end{array}$ \\
\hline CEO-Board Chairman Duality $[t-1]$ & $\begin{array}{c}-0.016 \\
(0.57)\end{array}$ & $\begin{array}{c}0.036^{* *} \\
(1.96)\end{array}$ & & \\
\hline Governance Index [t-1] & & & $\begin{array}{c}-0.015^{* *} \\
(2.4)\end{array}$ & $\begin{array}{c}-0.013^{* *} \\
(2.44)\end{array}$ \\
\hline CEO-Board Chairman Duality ${ }_{[t-1]}$ * & & & & \\
\hline Staggered Board $_{[t-1]}$ & $\begin{array}{c}0.089^{* * *} \\
(2.80)\end{array}$ & $\begin{array}{l}- \\
-\end{array}$ & & \\
\hline Governance Index $x_{[t-1]}$ * Staggered Board $[t-1]$ & & & $\begin{array}{l}0.004 \\
(0.64) \\
\end{array}$ & $\begin{array}{l}- \\
- \\
\end{array}$ \\
\hline Economic Significance (Staggered B.) & $6.26 \%$ & - & $4.86 \%$ & - \\
\hline Economic Significance (Int. Variable) & $5.10 \%$ & - & $1.28 \%$ & - \\
\hline Sample Period (Years) & $\begin{array}{c}1996- \\
2011\end{array}$ & - & $\begin{array}{c}1978- \\
2011\end{array}$ & - \\
\hline$N$ & 18,552 & 18,552 & 23,525 & 23,525 \\
\hline Adjusted R-2 & 0.73 & 0.73 & 0.711 & 0.711 \\
\hline Clustering of Standard Errors & Firm & Firm & Firm & Firm \\
\hline Firm \& Year Fixed Effect & Yes & Yes & Yes & Yes \\
\hline
\end{tabular}




\section{TABLE 11. Firm VALUe AND STAgGered BOARDS \\ INTERACTIONS OF STAGGERED BOARD WITH EXECUTIVE COMPENSATION}

In Table 11 we present time-series analysis as in Table 4 that includes interactions with variables that capture executive compensation. We include the following control variables: $L n$ (Assets) [t-1], Delaware Incorporation $[t-1], \mathrm{RO} A_{[-1]}, C A P X /$ ssets $_{[-1]}$, and R\&D/Sales $[t-1]$, which we do not show for brevity (unless a variable is being interacted with Staggered Board $[-1]$ ). The interacted variables include the following: CEO Delta $[-1]$, CEO Vega $[t-1]$, and CEO Total Compensation $\left[t_{t-1}\right.$. The sample period is 19782011. Individual interactions vary in their availability, as noted by the observation count and year span for each estimated model. All continuous variables in the interaction terms (CEO Delta $\left[\mathrm{t}_{1}\right]$, CEO $V$ ega $[t-1]$ and CEO Total Compensation $[-1])$ are demeaned prior to calculating their interactions with Staggered Board $[t-1]$. Estimation is using pooled panel Tobin's $Q_{[t]}$ regressions. We include year and firm fixed effects. All interaction and control variables are defined in Table 1. Economic significance for the interactions of the continuous interacted variables is calculated as the coefficient estimate times the standard deviation of the interacted variable, divided by the sample average for $Q_{[t]}$. Economic significance for Staggered Board $[t-1]$ is calculated as its coefficient estimate divided by average $Q_{[t]}$. Robust standard errors are clustered at the firm level. T-statistics (in their absolute value) are shown in parentheses below the coefficient estimates. Statistical significance of the coefficients is indicated at the $1 \%, 5 \%$, and $10 \%$ levels by ${ }^{* *}, * *$, and ${ }^{*}$, respectively. 
TABLE 11. Firm VALUE AND STAGGERED BOARDS

INTERACTIONS OF STAGGERED BOARD WITH EXECUTIVE COMPENSATION (CONTINUED)

\begin{tabular}{|c|c|c|c|c|c|c|}
\hline Variables & (1) & $(2)$ & (3) & (4) & (5) & (6) \\
\hline Staggered Board $_{[t-1]}$ & $\begin{array}{c}0.116^{* *} \\
(2.57)\end{array}$ & $\begin{array}{l}0.12^{* *} \\
(2.63)\end{array}$ & $\begin{array}{c}0.127^{* *} \\
(2.53)\end{array}$ & $\begin{array}{c}0.153^{* * *} \\
(3.04)\end{array}$ & $\begin{array}{c}0.104^{* *} \\
(2.52)\end{array}$ & $\begin{array}{c}0.126^{* * *} \\
(2.85)\end{array}$ \\
\hline CEO Delta $[t-1]$ & $\begin{array}{c}0.053^{* * *} \\
(4.65)\end{array}$ & $\begin{array}{c}0.058^{* * *} \\
(7.59)\end{array}$ & & & & \\
\hline CEO Vega $[t-1]$ & & & $\begin{array}{c}-0.072 \\
(1.31)\end{array}$ & $\begin{array}{l}0.025 \\
(0.56)\end{array}$ & & \\
\hline CEO Delta $[t-1] *$ Staggered Board $[t-1]$ & $\begin{array}{l}0.009 \\
(0.59)\end{array}$ & & & & & \\
\hline CEO Vega ${ }_{[t-1]} *$ Staggered Board $[t-1]$ & & & $\begin{array}{l}0.203^{* * *} \\
(2.87)\end{array}$ & & & \\
\hline Sample Period (Years) & $1992-2010$ & - & $1992-2010$ & - & $1992-2011$ & - \\
\hline$N$ & 17,573 & 17,573 & 15,983 & 15,983 & 17,965 & 17,965 \\
\hline Adjusted R-2 & 0.743 & 0.743 & 0.733 & 0.733 & 0.739 & 0.739 \\
\hline Clustering of Standard Errors & Firm & Firm & Firm & Firm & Firm & Firm \\
\hline Firm \& Year Fixed Effects & Yes & Yes & Yes & Yes & Yes & Yes \\
\hline
\end{tabular}


Appendix Tables To Cremers, Litov, SePE (2013) 


\section{APPENDix TABle A.1: Firm VALUe and STAGgERED BOARDS}

Table A.1 shows a replication of Bebchuk and Cohen (2005) with two different sets of control variables. Columns (1), (3) and (5) include the following control variables: Staggered Board $\left[{ }_{[-1]}\right.$, G-Index $[t-1]$, Ln (G-Index) $[t-1]$, Ln (Assets) $[[-1], \text { Ln (Firm Age })_{[-1]}$, Delaware Incorporation $\left[[-1], R O A_{[t-1]}, C A P X /\right.$ Assets $_{[-1]}$, and ReD/ Sales $s_{[-1]}$. In addition, column (5) includes $Q_{[-1]}$. Columns (2), (4) and (6) include the following control variables: Staggered

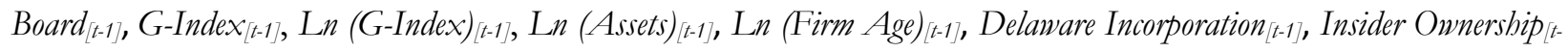
1], Insider Ownership ${ }_{[t-1]}, R O A_{[-1]}, C A P X / A_{s s e t s[t-1]}$, and R\&D/ Sales[t-1]. In addition, column (6) includes $Q_{[t-}$ 1]. The analysis includes 1978-2011 data. Estimation is using pooled panel Tobin's $Q_{[t]}$ regressions where year and industry fixed effects are included in columns (1), (2), (5) and (6). All control variables are defined in Table 1. Statistical significance of the coefficients is indicated at the $1 \%, 5 \%$, and $10 \%$ levels by ${ }^{* * *}$, ${ }^{* *}$, and *, respectively, in two tailed tests, based on robust standard errors clustered by firm. For the key independent variable—Staggered Board $[-1]$ — we show two separate standard errors: "(.)" reflects robust standard errors clustered at the firm level; "[.]" reflects robust standard errors that are independently clustered at the firm and year level. 
APPENDiX TABle A.1: Firm VAlue and Staggered BoARds (CONTINUED)

\begin{tabular}{|c|c|c|c|c|c|c|}
\hline & (1) & (2) & (3) & (4) & (5) & (6) \\
\hline \multirow[t]{2}{*}{$Q_{[t-1]}$} & - & - & - & - & $0.773^{* * *}$ & $0.759^{* * *}$ \\
\hline & - & - & - & - & $(73.05)$ & (63.98) \\
\hline Staggered Board $[-1]$ & $-0.059^{* * *}$ & $-0.043^{*}$ & $0.08^{* *}$ & $0.115^{* *}$ & $-0.015^{* *}$ & -0.011 \\
\hline (firm level cluster) & $(2.65)$ & $(1.72)$ & $(2.43)$ & $(2.53)$ & $(1.97)$ & $(1.16)$ \\
\hline [firm \& year level cluster] & {$[2.85]$} & {$[1.89]$} & -0.007 & 0.007 & {$[2.42]$} & {$[1.29]$} \\
\hline \multirow{2}{*}{ G-Index $[t-1]$} & -0.01 & -0.036 & $(0.58)$ & $(0.27)$ & -0.005 & $-0.014^{*}$ \\
\hline & $(0.96)$ & $(1.63)$ & -0.068 & -0.2 & $(1.45)$ & $(1.78)$ \\
\hline \multirow[t]{2}{*}{$\operatorname{Ln}(G-I n d e x)_{[t-1]}$} & 0.011 & 0.274 & $(0.86)$ & $(0.93)$ & 0.044 & $0.137^{*}$ \\
\hline & $(0.14)$ & $(1.32)$ & $-0.159^{* * *}$ & $-0.226^{* * *}$ & $(1.56)$ & $(1.77)$ \\
\hline \multirow[t]{2}{*}{$\operatorname{Ln}(\text { Assets })_{[t-1]}$} & -0.009 & -0.006 & $(7.47)$ & $(8.57)$ & $-0.006^{* *}$ & -0.006 \\
\hline & $(0.91)$ & $(0.53)$ & -0.053 & 0.006 & $(2.23)$ & $(1.46)$ \\
\hline \multirow[t]{2}{*}{ 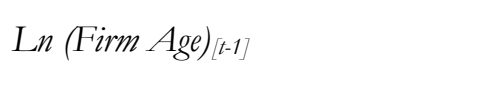 } & -0.02 & -0.027 & $(1.28)$ & $(0.09)$ & 0.003 & 0.01 \\
\hline & $(1.48)$ & $(1.09)$ & & & $(0.8)$ & $(1.16)$ \\
\hline \multirow{2}{*}{ Delaware Incorporation ${ }_{[-1]}$} & -0.012 & -0.021 & & & -0.002 & -0.005 \\
\hline & $(0.50)$ & $(0.77)$ & & 0.162 & $(0.31)$ & $(0.5)$ \\
\hline \multirow{2}{*}{ Insider Ownership $[t-1]$} & - & 0.188 & & $(0.66)$ & - & 0.102 \\
\hline & - & $(0.81)$ & & -0.341 & - & $(1.06)$ \\
\hline \multirow[t]{2}{*}{ Insider Ownership ${ }^{2}[t-1]$} & - & -0.228 & & $(1.1)$ & - & -0.07 \\
\hline & - & $(0.73)$ & $3.547^{* * *}$ & $3.532^{* * *}$ & - & $(0.48)$ \\
\hline \multirow[t]{2}{*}{$\mathrm{RO} A_{[t-1]}$} & $5.308^{* * *}$ & $5.745^{* * *}$ & $(19.31)$ & $(17.44)$ & $0.58^{* * *}$ & $0.664^{* * *}$ \\
\hline & $(24.58)$ & $(23.88)$ & 0.163 & 0.194 & $(7.16)$ & $(6.33)$ \\
\hline \multirow[t]{2}{*}{$C A P X / A$ ssets $_{[-1]]}$} & $-0.626^{* *}$ & $-0.719^{*}$ & $(0.75)$ & $(0.69)$ & $-0.364^{* * *}$ & $-0.378^{* * *}$ \\
\hline & $(2.08)$ & $(1.9)$ & $1.79^{* *}$ & 0.572 & $(3.58)$ & $(2.83)$ \\
\hline \multirow{2}{*}{ R\&D/Sales $[[-1]$} & $4.331^{* * *}$ & $4.213^{* * *}$ & $(2.58)$ & $(0.7)$ & $0.905^{* * *}$ & $0.829^{* * *}$ \\
\hline & $(8.09)$ & $(7.29)$ & $0.08^{* *}$ & $0.115^{* *}$ & $(4.61)$ & $(3.74)$ \\
\hline $\mathrm{N}$ & 19,743 & 14,376 & 19,743 & 14,376 & 18,522 & 13,742 \\
\hline Adjusted R-Squared & 0.566 & 0.58 & 0.707 & 0.724 & 0.8 & 0.798 \\
\hline Year Effect & Yes & Yes & Yes & Yes & Yes & Yes \\
\hline Industry Effect & $\underline{\text { Yes }}$ & $\underline{\text { Yes }}$ & No & No & $\underline{\text { Yes }}$ & $\underline{\text { Yes }}$ \\
\hline Firm Effect & No & No & $\underline{\text { Yes }}$ & $\underline{\text { Yes }}$ & No & No \\
\hline Clustering & Firm & Firm & Firm & Firm & Firm & Firm \\
\hline
\end{tabular}




\section{ApPendiX TABle A.2: Firm VAlue and STAggered BoARDS - First DifFERENCES}

Table A.2, Panel A presents pooled panel first difference regressions with the dependent variable being the change in $\mathrm{Q}$ from $\mathrm{t}$ to $\mathrm{t}+1$ in column (1) (i.e., $\Delta \mathrm{Q}_{[\mathrm{t}, \mathrm{t}+1]}$ ), the change in $\mathrm{Q}$ from $\mathrm{t}$ to $\mathrm{t}+2$ in column (2) (i.e., $\Delta$ $\mathrm{Q}_{[\mathrm{t}, \mathrm{t}+2]}$ ), the change in $\mathrm{Q}$ from $\mathrm{t}$ to $\mathrm{t}+3$ in column (3) (i.e., $\Delta \mathrm{Q}_{[\mathrm{t}, \mathrm{t}+3]}$ ), the change in $\mathrm{Q}$ from $\mathrm{t}$ to $\mathrm{t}+4$ in column (4) (i.e., $\Delta \mathrm{Q}_{[\mathrm{t}, \mathrm{t}+4]}$ ), and the change in $\mathrm{Q}$ from $\mathrm{t}$ to $\mathrm{t}+5$ in column (5) (i.e., $\Delta \mathrm{Q}_{[\mathrm{t}, \mathrm{t}+5]}$ ). Table A.2, Panel $\mathrm{B}$ presents pooled panel first difference regressions with the dependent variable being the change in $\mathrm{Q}$ from $\mathrm{t}-1$ to $\mathrm{t}$ in column (1) (i.e., $\Delta \mathrm{Q}_{[\mathrm{t}-1, \mathrm{t}]}$ ), the change in $\mathrm{Q}$ from $\mathrm{t}-1$ to $\mathrm{t}+1$ in column (2) (i.e., $\Delta \mathrm{Q}_{[\mathrm{t}-1, \mathrm{t}+1]}$ ), the change in $\mathrm{Q}$ from $\mathrm{t}-1$ to $\mathrm{t}+2$ in column (3) (i.e., $\Delta \mathrm{Q}_{[\mathrm{t}-1, \mathrm{t}+2]}$ ), , the change in $\mathrm{Q}$ from $\mathrm{t}-1$ to $\mathrm{t}+3$ in column (4) (i.e., $\Delta \mathrm{Q}_{[\mathrm{t}-1, \mathrm{t}+3]}$ ), and the change in $\mathrm{Q}$ from $\mathrm{t}-1$ to $\mathrm{t}+4$ in column (5) (i.e., $\left.\Delta \mathrm{Q}_{[\mathrm{t}-1, \mathrm{t}+4]}\right)$. As independent variables, we include the following: $\Delta$ Staggered Board $_{[-1]}, \Delta G$-Index $[-1], \Delta L n$ (G-Index) $)_{[-1]}, \Delta L n$ (Assets) $[[-1], \Delta L n$

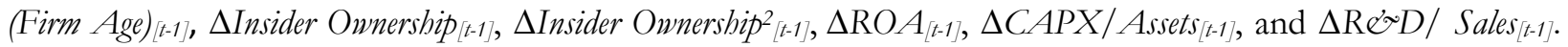
The change in the indicator variable, $\Delta$ Delaware Incorporation $_{[t-1]}$, is not included due to limited variation. Sample period is 1978-2011, but varies per model due to availability of lagged data and is reported for each model. Regressions exclude fixed effects at the firm, year, or industry levels. Standard errors are clustered at the firm level. Results are robust to an adjustment to the standard errors for autocorrelation as in Newey-West (where the adjustment includes up to sixth lags). T-statistics (in their absolute value) of the regression coefficients are shown in parentheses below the coefficient estimates. Statistical significance of the coefficients is indicated at the $1 \%, 5 \%$, and $10 \%$ levels by ${ }^{* * *},{ }^{* *}$, and ${ }^{*}$, respectively, in two tailed tests. All control variables are defined in Table 1. Our sample for Column (1) in Panel A includes 351 cases of staggering up and 307 cases of staggering down. Our sample for Column (1) in Panel B includes 341 cases of staggering up and 272 cases of staggering down. The number of firms per regression model is noted in the table. 
appendix Table A.2, Panel A. Future Changes in Q vs. Past Changes in Control Variables

\begin{tabular}{|c|c|c|c|c|c|c|c|c|c|c|}
\hline Dep. Variable: & $\Delta \mathrm{Q}_{[\mathrm{t}, \mathrm{t}+1]}$ & $\Delta \mathrm{Q}_{[\mathrm{t}, \mathrm{t}+1]}$ & $\Delta \mathrm{Q}_{[\mathrm{t}, \mathrm{t}+2]}$ & $\Delta \mathrm{Q}_{[\mathrm{t}, \mathrm{t}+2]}$ & $\Delta \mathrm{Q}_{[\mathrm{t}, \mathrm{t}+3]}$ & $\Delta \mathrm{Q}_{[\mathrm{t}, \mathrm{t}+3]}$ & $\Delta \mathrm{Q}_{[\mathrm{t}, \mathrm{t}+4]}$ & $\Delta \mathrm{Q}_{[\mathrm{t}, \mathrm{t}+4]}$ & $\Delta \mathrm{Q}_{[\mathrm{t}, \mathrm{t}+5]}$ & $\Delta \mathrm{Q}_{[\mathrm{t}, \mathrm{t}+5]}$ \\
\hline & (1) & $(2)$ & $(3)$ & (4) & (5) & $(6)$ & $(7)$ & $(8)$ & (9) & $(10)$ \\
\hline \multirow{2}{*}{$\Delta$ Staggered Board $[t-1]$} & $0.038^{* *}$ & $0.043^{*}$ & $0.072^{* *}$ & $0.128^{* * *}$ & $0.093^{* * *}$ & $0.152^{* * *}$ & $0.08^{* *}$ & $0.12^{*}$ & $0.116^{* *}$ & $0.169^{* *}$ \\
\hline & $(2.12)$ & $(1.83)$ & $(2.47)$ & (3.13) & $(2.92)$ & $(3.21)$ & $(2.09)$ & $(1.94)$ & $(2.62)$ & $(2.37)$ \\
\hline \multirow[t]{2}{*}{$\Delta G-I n d e x_{[t-1]}$} & -0.012 & $-0.028^{*}$ & 0.004 & 0.025 & -0.004 & 0.0001 & 0.003 & 0.011 & -0.001 & -0.007 \\
\hline & $(1.63)$ & $(1.69)$ & $(0.36)$ & $(1.20)$ & $(0.32)$ & $(0.02)$ & $(0.24)$ & $(0.38)$ & $(0.09)$ & $(0.23)$ \\
\hline \multirow[t]{2}{*}{$\Delta \operatorname{Ln}(G-I n d e x)_{[t-1]}$} & $0.112^{* *}$ & 0.239 & 0.02 & -0.154 & $0.187^{* *}$ & 0.155 & $0.182^{* *}$ & 0.083 & $0.296^{* * *}$ & 0.283 \\
\hline & $(2.17)$ & $(1.52)$ & $(0.27)$ & $(0.87)$ & $(2.15)$ & $(0.60)$ & $(1.97)$ & $(0.32)$ & $(3.05)$ & $(1.17)$ \\
\hline \multirow[t]{2}{*}{$\Delta \operatorname{Ln}(\text { Assets })_{[t-1]}$} & $-0.281^{* * *}$ & $-0.305^{* * *}$ & $-0.473^{* * *}$ & $-0.549^{* * *}$ & $-0.517^{* * *}$ & $-0.601^{* * *}$ & $-0.53^{* * *}$ & $-0.606^{* * *}$ & $-0.573^{* * *}$ & $-0.643^{* * *}$ \\
\hline & $(10.39)$ & $(9.16)$ & $(12.18)$ & $(11.49)$ & $(11.44)$ & $(10.77)$ & $(11.42)$ & $(10.83)$ & $(10.98)$ & $(9.79)$ \\
\hline \multirow[t]{2}{*}{$\Delta \operatorname{Ln}(\text { Firm Age })_{[t-1]}$} & 0.016 & -0.019 & 0.107 & 0.174 & 0.165 & 0.214 & 0.257 & 0.372 & 0.214 & 0.376 \\
\hline & $(0.29)$ & $(0.18)$ & $(1.07)$ & $(1.09)$ & $(1.25)$ & $(0.98)$ & $(1.60)$ & $(1.40)$ & $(1.16)$ & $(1.25)$ \\
\hline \multirow[t]{2}{*}{$\Delta$ Insider Ownership ${ }_{[t-1]}$} & - & -0.055 & - & 0.188 & - & 0.279 & - & 0.168 & - & $0.672^{* *}$ \\
\hline & - & $(0.24)$ & - & $(0.69)$ & - & $(1.12)$ & - & $(0.68)$ & - & $(2.44)$ \\
\hline \multirow[t]{2}{*}{$\Delta$ Insider Ownershipit ${ }^{[t-1]}$} & - & 0.182 & - & -0.142 & - & -0.174 & - & -0.059 & - & -0.457 \\
\hline & - & $(0.77)$ & - & $(0.51)$ & - & $(0.67)$ & - & $(0.23)$ & - & $(1.56)$ \\
\hline \multirow[t]{2}{*}{$\Delta R O A_{[t-1]}$} & $-0.183^{*}$ & -0.161 & $-0.598^{* * *}$ & $-0.804^{* * *}$ & $-1.239^{* * *}$ & $-1.582^{* * *}$ & $-1.313^{* * *}$ & $-1.867^{* * *}$ & $-1.386^{* * *}$ & $-1.901^{* * *}$ \\
\hline & $(1.74)$ & $(1.31)$ & $(5.01)$ & $(5.12)$ & $(8.46)$ & (7.61) & $(8.35)$ & $(8.05)$ & $(8.18)$ & $(7.34)$ \\
\hline \multirow[t]{2}{*}{$\Delta C A P X / A_{\text {ssets }}^{[t-1]}$} & $-0.644^{* * *}$ & $-1.034^{* * *}$ & $-0.754^{* * *}$ & $-1.125^{* * *}$ & $-0.872^{* * *}$ & $-1.29^{* * *}$ & $-0.934^{* * *}$ & $-1.333^{* * *}$ & $-0.828^{* * *}$ & $-1.248^{* * *}$ \\
\hline & $(3.72)$ & $(4.73)$ & $(3.78)$ & $(4.4)$ & $(4.23)$ & $(4.42)$ & $(4.68)$ & $(4.49)$ & $(3.64)$ & $(3.87)$ \\
\hline \multirow[t]{2}{*}{$\Delta R \mho D /$ Sales $_{[-1]}$} & 0.979 & 0.783 & 0.438 & 0.178 & -0.039 & -0.862 & 0.649 & -0.61 & 0.314 & -0.491 \\
\hline & $(1.53)$ & $(1.39)$ & $(0.66)$ & $(0.27)$ & $(0.05)$ & $(1.03)$ & $(0.89)$ & $(0.79)$ & $(0.37)$ & $(0.49)$ \\
\hline $\mathrm{N}$ & 18,428 & 12,469 & 17,555 & 11,699 & 16,667 & 10,925 & 15,783 & 10,170 & 14,914 & 9,425 \\
\hline Adjusted R-Squared & 0.014 & 0.016 & 0.022 & 0.029 & 0.024 & 0.03 & 0.023 & 0.028 & 0.023 & 0.026 \\
\hline
\end{tabular}


Appendix Table A.2: Panel B. Future Changes in Q vs. Past Changes in Control Variables With STANDARD ERrors Clustered at THE FIRM LEVEL

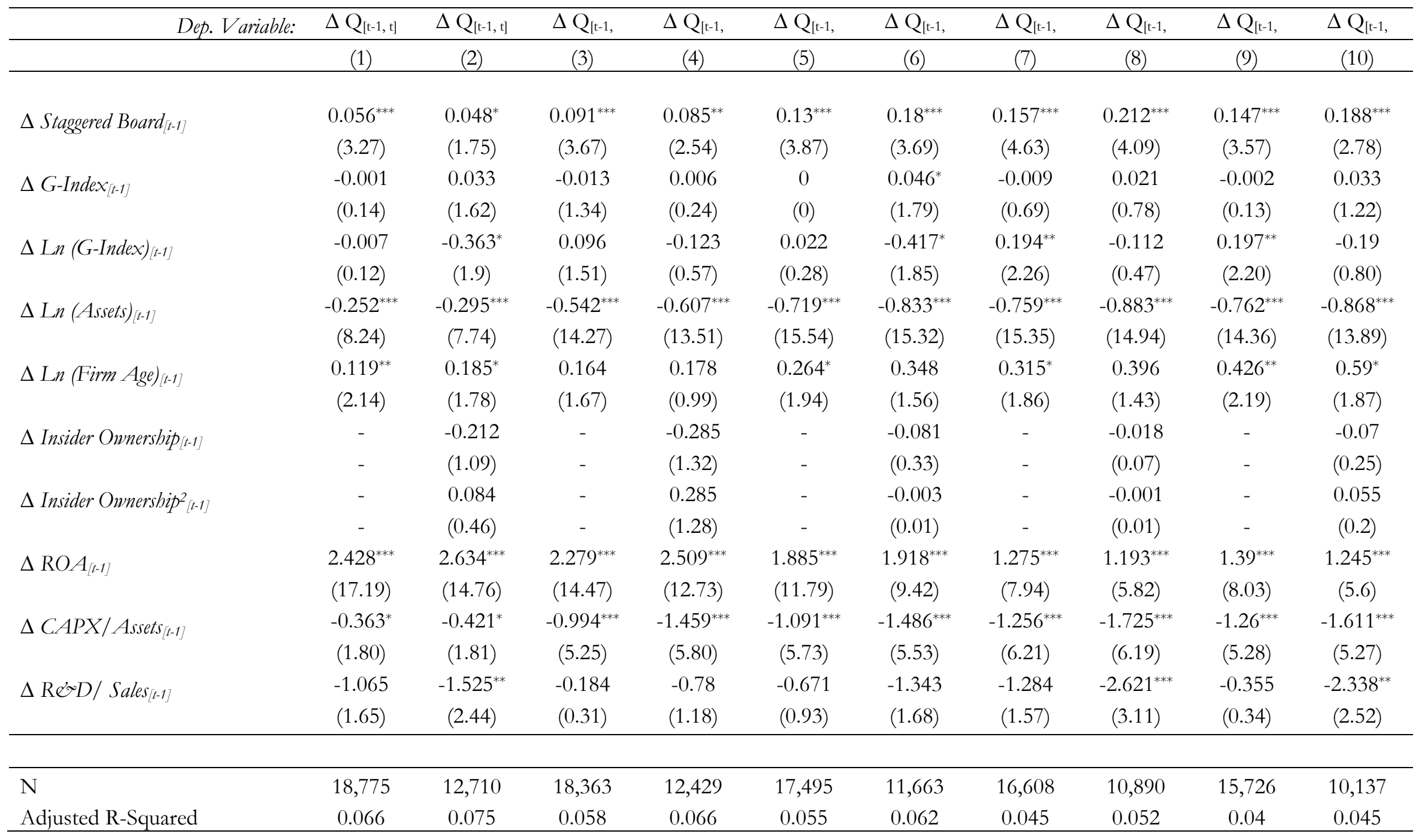


APpendix TABle A.3: Firm VAlue AND STAggered BoARDS: REVERSE CAUSALITY TESTS

Table A.3 presents reverse causality regressions to explain the adoption (in Panel A) and removal (in Panel B) of a staggered board as a function of the valuation of the firm (as captured by $\mathcal{Q}_{[t}$ ) plus other characteristics. The sample for Panel B (A) includes all firms that do (not) have a staggered board up until (and including) the year in which they remove (adopt) the staggered board if there is any such change, and are dropped from the sample afterwards. Each panel shows three sets of models. Columns (1) and (2) use a random effects Probit model, with robust standard errors clustered by firm and reporting marginal effects. Columns (3) and (4) use the Cox proportional hazard model (Greene, 2000) and report the hazard ratio using robust standard errors clustered at the firm level (after standardizing the continuous variables to have zero mean and unit variance). Dual-class stocks are removed from the sample. Statistical significance of the coefficients is indicated at the $1 \%, 5 \%$, and $10 \%$ levels by ${ }^{* * *},{ }^{* *}$, and ${ }^{*}$, respectively, in two tailed tests. T-statistics (in their absolute value) are shown in parentheses below the coefficient estimates. All control variables are defined in Table 1. The sample in the table refers to the time period 1978-2011. 
APPENDix TABle A.3: Firm VALUE AND STAGgERED BOARDS: REVERSE CAUSALITY TESTS (CONTINUED)

Panel A. Predict Staggering UP

\begin{tabular}{|c|c|c|c|c|}
\hline Dep. Variable is: $\operatorname{Pr}$ (Stagger in $\mathrm{t}$ ) & $\begin{array}{c}\text { Random } \\
\text { Effects } \\
\text { Probit } \\
\text { Model }\end{array}$ & $\begin{array}{c}\text { Random } \\
\text { Effects } \\
\text { Probit } \\
\text { Model }\end{array}$ & $\begin{array}{l}\text { Cox } \\
\text { Model }\end{array}$ & $\begin{array}{l}\text { Cox } \\
\text { Model }\end{array}$ \\
\hline Variables & (1) & (2) & (3) & (4) \\
\hline$Q[t-1]$ & $\begin{array}{c}-0.005^{* * *} \\
(2.64)\end{array}$ & $\begin{array}{c}-0.001^{* *} \\
(2.25)\end{array}$ & $\begin{array}{c}0.419^{* * *} \\
(6.35)\end{array}$ & $\begin{array}{c}0.493^{* * *} \\
(3.14)\end{array}$ \\
\hline$G-I n d e x[t-1]$ & $\begin{array}{c}-0.005^{* * *} \\
(2.94)\end{array}$ & $\begin{array}{l}-0.001 \\
(0.99)\end{array}$ & $\begin{array}{l}0.472 \\
(1.43)\end{array}$ & $\begin{array}{l}0.411 \\
(0.93)\end{array}$ \\
\hline $\operatorname{Ln}(G-I n d e x)[t-1]$ & $\begin{array}{c}0.057^{* * *} \\
(3.6)\end{array}$ & $\begin{array}{l}0.008 \\
(1.29)\end{array}$ & $\begin{array}{c}4.761^{* * *} \\
(2.68)\end{array}$ & $\begin{array}{l}6.601 \\
(1.61)\end{array}$ \\
\hline $\operatorname{Ln}($ Assets $)[t-1]$ & $\begin{array}{l}-0.001 \\
(1.64)\end{array}$ & $\begin{array}{c}-0.00002 \\
(0.13)\end{array}$ & $\begin{array}{l}1.17^{*} \\
(1.94)\end{array}$ & $\begin{array}{l}1.105 \\
(0.65)\end{array}$ \\
\hline Ln (Firm Age) $[t-1]$ & $\begin{array}{c}-0.002^{*} \\
(1.83)\end{array}$ & $\begin{array}{c}-0.00024 \\
(0.53)\end{array}$ & $\begin{array}{l}1.065 \\
(0.75)\end{array}$ & $\begin{array}{l}1.344 \\
(1.2)\end{array}$ \\
\hline Delaware Incorporation [t-1] & $\begin{array}{l}-0.002 \\
(1.06)\end{array}$ & $\begin{array}{c}-0.00049 \\
(0.85)\end{array}$ & $\begin{array}{c}0.96 \\
(0.54)\end{array}$ & $\begin{array}{l}0.956 \\
(0.32)\end{array}$ \\
\hline Insider Ownership[t-1] & & $\begin{array}{c}0.00025 \\
(0.07)\end{array}$ & & $\begin{array}{l}0.952 \\
(0.18)\end{array}$ \\
\hline Insider Ownership2[t-1] & & $\begin{array}{c}0.001 \\
(0.1)\end{array}$ & & $\begin{array}{l}1.205 \\
(0.97)\end{array}$ \\
\hline $\mathrm{RO} A[t-1]$ & $\begin{array}{l}0.028^{* *} \\
(2.09)\end{array}$ & $\begin{array}{l}0.005 \\
(1.07)\end{array}$ & $\begin{array}{l}1.65^{* * *} \\
(4.83)\end{array}$ & $\begin{array}{c}1.669^{* *} \\
(2.37)\end{array}$ \\
\hline$C A P X / A s s e t s[t-1]$ & $\begin{array}{l}0.048^{* *} \\
(2.62)\end{array}$ & $\begin{array}{l}0.002 \\
(0.51)\end{array}$ & $\begin{array}{c}1.215^{* * *} \\
(2.78)\end{array}$ & $\begin{array}{l}1.074 \\
(0.5)\end{array}$ \\
\hline R\&D/Sales[t-1] & $\begin{array}{l}-0.028 \\
(1.49) \\
\end{array}$ & $\begin{array}{c}-0.002 \\
(0.36) \\
\end{array}$ & $\begin{array}{l}0.938 \\
(0.56) \\
\end{array}$ & $\begin{array}{r}1.07 \\
(0.34)\end{array}$ \\
\hline $\mathrm{N}$ & 9,335 & 6,067 & 8,772 & 5,542 \\
\hline Pseudo R-2 & - & - & 0.059 & 0.062 \\
\hline $\begin{array}{l}\text { Adjusted R-2 } \\
\text { Wald Chi-2 (p-value) }\end{array}$ & $\begin{array}{c}- \\
61.5 \\
(0.00)\end{array}$ & $\begin{array}{c}- \\
18.18 \\
(0.078)\end{array}$ & - & - \\
\hline
\end{tabular}


APPENDix TABle A.3: Firm VALUE AND STAGgERED BOARDS: REVERSE CAUSALITY TESTS (CONTINUED)

PANEL B. PREDICT DE-STAGGERING

\begin{tabular}{|c|c|c|c|c|}
\hline Dep. Variable is: $\operatorname{Pr}$ (Stagger in $\mathrm{t}$ ) & $\begin{array}{c}\text { Random } \\
\text { Effects } \\
\text { Probit } \\
\text { Model }\end{array}$ & $\begin{array}{c}\text { Random } \\
\text { Effects } \\
\text { Probit } \\
\text { Model }\end{array}$ & $\begin{array}{l}\text { Cox } \\
\text { Model }\end{array}$ & $\begin{array}{l}\text { Cox } \\
\text { Model }\end{array}$ \\
\hline Variables & $(1)$ & $(2)$ & (3) & (4) \\
\hline$Q[t-1]$ & $\begin{array}{l}-0.001 \\
(1.05)\end{array}$ & $\begin{array}{c}-0.00033 \\
(0.18)\end{array}$ & $\begin{array}{l}1.083 \\
(0.43)\end{array}$ & $\begin{array}{l}1.038 \\
(0.17)\end{array}$ \\
\hline G-Index [t-1] & $\begin{array}{l}0.001 \\
(0.47)\end{array}$ & $\begin{array}{l}-0.003 \\
(1.45)\end{array}$ & $\begin{array}{l}2.326 \\
(1.32)\end{array}$ & $\begin{array}{c}2.968^{* *} \\
(2.1)\end{array}$ \\
\hline $\operatorname{Ln}(G-I n d e x)[t-1]$ & $\begin{array}{l}-0.005 \\
(0.33)\end{array}$ & $\begin{array}{l}0.042^{*} \\
(1.86)\end{array}$ & $\begin{array}{c}0.304 \\
(1.3)\end{array}$ & $\begin{array}{c}0.205^{* *} \\
(2.19)\end{array}$ \\
\hline $\operatorname{Ln}($ Assets $)[t-1]$ & $\begin{array}{c}-0.005^{* * *} \\
(7.26)\end{array}$ & $\begin{array}{c}-0.006^{* * *} \\
(6.66)\end{array}$ & $\begin{array}{c}1.753^{* * *} \\
(3.93)\end{array}$ & $\begin{array}{l}1.75^{* * *} \\
(3.78)\end{array}$ \\
\hline Ln (Firm Age) $[t-1]$ & $\begin{array}{c}-0.007^{* * *} \\
(4.23)\end{array}$ & $\begin{array}{c}-0.008^{* * *} \\
(3.26)\end{array}$ & $\begin{array}{c}1.31 \\
(1.11)\end{array}$ & $\begin{array}{l}1.115 \\
(0.42)\end{array}$ \\
\hline Delaware Incorporation [t-1] & $\begin{array}{l}-0.001 \\
(0.54)\end{array}$ & $\begin{array}{c}-0.00039 \\
(0.17)\end{array}$ & $\begin{array}{l}1.016 \\
(0.15)\end{array}$ & $\begin{array}{c}0.969 \\
(0.3)\end{array}$ \\
\hline Insider Ownership [t-1] & & $\begin{array}{c}0.04387 \\
(1.57)\end{array}$ & & $\begin{array}{c}0.53 \\
(1.61)\end{array}$ \\
\hline Insider Ownership2[t-1] & & $\begin{array}{c}-0.073^{* *} \\
(2.21)\end{array}$ & & $\begin{array}{c}1.749^{* *} \\
(2.01)\end{array}$ \\
\hline $\mathrm{RO} A[t-1]$ & $\begin{array}{l}0.03^{*} \\
(1.78)\end{array}$ & $\begin{array}{l}0.019 \\
(0.83)\end{array}$ & $\begin{array}{l}0.964 \\
(0.22)\end{array}$ & $\begin{array}{l}0.998 \\
(0.01)\end{array}$ \\
\hline$C A P X / A s s e t s[t-1]$ & $\begin{array}{l}0.021 \\
(0.86)\end{array}$ & $\begin{array}{l}0.037 \\
(1.17)\end{array}$ & $\begin{array}{l}0.994 \\
(0.06)\end{array}$ & $\begin{array}{l}0.954 \\
(0.47)\end{array}$ \\
\hline ReD/Sales[t-1] & $\begin{array}{l}-0.024 \\
(1.16) \\
\end{array}$ & $\begin{array}{r}-0.043^{*} \\
(1.69) \\
\end{array}$ & $\begin{array}{l}1.075 \\
(0.57) \\
\end{array}$ & $\begin{array}{c}1.105 \\
(0.8)\end{array}$ \\
\hline $\mathrm{N}$ & 10,745 & 8,537 & 7605 & 5924 \\
\hline Pseudo R-2 & - & - & 0.023 & 0.032 \\
\hline $\begin{array}{l}\text { Adjusted R-2 } \\
\text { Wald Chi-2 (p-value) }\end{array}$ & $\begin{array}{c}- \\
116.9 \\
(0.00)\end{array}$ & $\begin{array}{c}- \\
108.3 \\
(0.00)\end{array}$ & - & - \\
\hline
\end{tabular}




\section{Appendix Table A.4: Firm Value And Staggered Boards}

\section{INTERACTIONS OF STAGGERED BOARD WITH INVESTMENTS AND OPERATIONAL COMPLEXITY}

Table A.4 presents time-series analysis as in Table 4 that includes interactions with variables that capture investments and operational complexity. We include the following control variables. In columns(1), (3), (5)

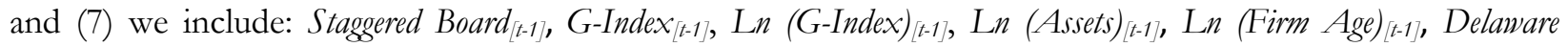

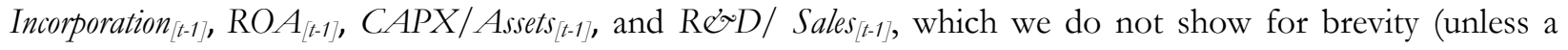
variable is being interacted with Staggered Board $[t-1]$. In columns(2), (4), (6) and (8) we include: Staggered Board $[$ -

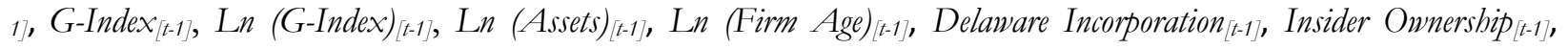
Insider Ownership ${ }^{2[-1]}, R O A_{[t-1]}, C A P X / A_{\text {ssets }[t-1]}$, and R\&D/ Sales $[-1]$, which we do not show for brevity (unless a variable is being interacted with Staggered Board $[-1]$. The interacted variables include the following: R\&D/

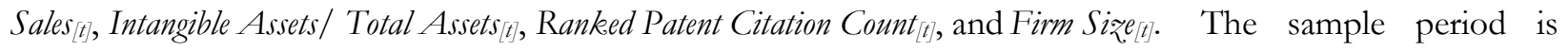
1978-2011. Individual interactions vary in their availability, as noted by the observation count and year span for each estimated model. All continuous variables in the interaction terms (ReD/ Sales $[t]$, Intangible Assets/Total Assets $[t]$, and Firm Size $[t])$ are demeaned prior to calculating their interactions with Staggered Board $[$ 1]. Estimation is using pooled panel Tobin's $Q_{[t]}$ regressions. We include (but do not show for brevity) year and firm fixed effects. All interaction and control variables are defined in Table 1. Standard errors are clustered at the firm level. T-statistics (in their absolute value) are shown in parentheses below the coefficient estimates.

Statistical significance of the coefficients is indicated at the $1 \%, 5 \%$, and $10 \%$ levels by ${ }^{* *}$, **, and *, respectively, in two tailed tests. 
APPEndix TABle A.4: Firm Value And Staggered BoArds

INTERACTIONS OF STAGGERED BOARD WITH INVESTMENTS AND OPERATIONAL COMPLEXITY (CONTINUED)

\begin{tabular}{|c|c|c|c|c|c|c|c|c|}
\hline Variables & (1) & (2) & (3) & (4) & (5) & (6) & (7) & (8) \\
\hline Staggered Board $_{[t-1]}$ & $\begin{array}{c}0.101^{* * *} \\
(2.96)\end{array}$ & $\begin{array}{c}0.129^{* * *} \\
(2.87)\end{array}$ & $\begin{array}{c}0.097^{* * *} \\
(2.72)\end{array}$ & $\begin{array}{c}0.131^{* * *} \\
(2.64)\end{array}$ & $\begin{array}{l}0.059 \\
(1.25)\end{array}$ & $\begin{array}{l}0.073 \\
(0.88)\end{array}$ & $\begin{array}{l}0.053^{*} \\
(1.64)\end{array}$ & $\begin{array}{l}0.057 \\
(1.26)\end{array}$ \\
\hline R\&D/Sales $[t-1]$ & $\begin{array}{c}0.177 \\
(0.2)\end{array}$ & $\begin{array}{c}-0.806 \\
(0.84)\end{array}$ & - & - & - & - & - & - \\
\hline Intangible Assets/ Total Assets[t-1] & - & - & $\begin{array}{l}0.017 \\
(0.39)\end{array}$ & $\begin{array}{l}0.044 \\
(0.81)\end{array}$ & - & - & - & - \\
\hline Ranked Patent Citation Count ${ }_{[t-1]}$ & - & - & - & - & $\begin{array}{c}-0.051 \\
(0.45)\end{array}$ & $\begin{array}{l}0.096 \\
(0.62)\end{array}$ & - & - \\
\hline Firm Size $[t-1]$ & - & - & - & - & - & - & $\begin{array}{c}-0.009 \\
(0.27)\end{array}$ & $\begin{array}{r}-0.021 \\
(0.55)\end{array}$ \\
\hline ReD / Salest-1 $^{*}$ Staggered Board $_{[t-1]}$ & $\begin{array}{c}3.058^{* * *} \\
(3.39)\end{array}$ & $\begin{array}{c}2.817^{* * *} \\
(3.18)\end{array}$ & - & - & - & - & - & - \\
\hline $\begin{array}{l}\text { Intangible Assets/ Total Assets }[t-1] \\
\text { Staggered Board }_{[-1]}\end{array}$ & - & $\begin{array}{l}- \\
-\end{array}$ & $\begin{array}{c}0.115^{* *} \\
(2.48)\end{array}$ & $\begin{array}{l}0.109^{*} \\
(1.75)\end{array}$ & - & - & - & - \\
\hline $\begin{array}{l}\text { Ranked Patent Citation Count }{ }_{[t-1]} \text { * } \\
\text { Staggered Board } \\
{[t-1]}\end{array}$ & - & - & - & - & $0.309^{* *}$ & 0.179 & - & - \\
\hline & - & - & - & - & $(2.22)$ & $(1.01)$ & - & - \\
\hline Firm Size $[t-1]^{*}$ Staggered Board $[t-1]$ & - & - & - & - & - & - & $\begin{array}{l}0.04^{* *} \\
(2.20)\end{array}$ & $\begin{array}{l}0.057^{* *} \\
(2.37)\end{array}$ \\
\hline Sample Period (Years) & $\begin{array}{l}1978- \\
2011 \\
\end{array}$ & - & $\begin{array}{c}1978- \\
2011 \\
\end{array}$ & - & $\begin{array}{c}1978- \\
2003\end{array}$ & - & $\begin{array}{c}1978- \\
2011 \\
\end{array}$ & - \\
\hline$N$ & 19,743 & 14,376 & 19,628 & 14,285 & 10,781 & 6,714 & 19,738 & 14,372 \\
\hline Adjusted R-2 & 0.71 & 0.72 & 0.71 & 0.72 & 0.71 & 0.73 & 0.71 & 0.72 \\
\hline Clustering of Standard Errors & Firm & Firm & Firm & Firm & Firm & Firm & Firm & Firm \\
\hline Firm Fixed Effect & Yes & Yes & Yes & Yes & Yes & Yes & Yes & Yes \\
\hline
\end{tabular}




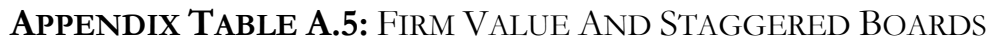

\section{INTERACTIONS OF STAGGERED BOARD WITH BOARD FEATURES AND GOVERNANCE PROVISIONS}

In Table A.5 we present time-series analysis as in Table 4 that includes interactions with variables that capture board features and governance provisions. We include the following control variables. In columns(1) and (3) we include: Staggered Board $[t-1]$, G-Index $_{[t-1]}, \operatorname{Ln}(G-I n d e x)_{[t-1]}$, Ln (Assets) $[[-1], \text { Ln (Firm Age })_{[t-1]}$, Delaware Incorporation $[t-$ 1], ROA $A_{[t-1]}, C A P X / A_{\text {ssets }[t-1]}$, and R\&D/ Sales $[t-1]$, which we do not show for brevity (unless a variable is being interacted with Staggered Board $[t-1]$. In columns(2) and (4) we include: Staggered Board $[-1]$, G-Index $[t-1]$, Ln $(G-$ Index) ${ }_{[t-1]}$, Ln (Assets) ${ }_{[-1]}$, Ln (Firm Age $]_{[-1]}$, Delaware Incorporation ${ }_{[-1]}$, Insider Ownership $[t-1]$, Insider Ownership ${ }_{[-1-1]}$, $\mathrm{ROA} A_{[t-1]}, C A P X /$ Assets $_{[t-1]}$, and ReD/ Sales $[t-1]$, which we do not show for brevity (unless a variable is being interacted with Staggered Board $[-1]$ ). The sample period is 1978-2011. Individual interactions vary in their availability, as noted by the observation count and year span for each estimated model. The $G$-Index [t-1] is demeaned prior to calculating its interaction with Staggered Board $[t-1]$. Estimation is using pooled panel Tobin's $Q_{[t]}$ regressions. We include (but do not show for brevity) year and firm fixed effects. All interaction and control variables are defined in Table 1. Standard errors are clustered at the firm level. T-statistics (in their absolute value) are shown in parentheses below the coefficient estimates. Statistical significance of the coefficients is indicated at the $1 \%, 5 \%$, and $10 \%$ levels by ${ }^{* * *}$, ${ }^{* *}$, and ${ }^{*}$, respectively, in two tailed tests. 
Appendix TABle A.5: Firm Value And Staggered BoARds

INTERACTIONS OF STAGGERED BOARD WITH BOARD FEATURES AND GOVERNANCE PROVISIONS (CONTINUED)

\begin{tabular}{|c|c|c|c|c|}
\hline Variables & $(1)$ & $(2)$ & (3) & (4) \\
\hline Staggered Board $_{[-1]}$ & $\begin{array}{l}0.079^{* *} \\
(2.38)\end{array}$ & $\begin{array}{l}0.111^{* *} \\
(2.09)\end{array}$ & $\begin{array}{l}0.108^{*} \\
(1.90)\end{array}$ & $\begin{array}{l}0.11^{*} \\
(1.96)\end{array}$ \\
\hline CEO-Board Chairman Duality ${ }_{[t-1]}$ & $\begin{array}{c}-0.011 \\
(0.83)\end{array}$ & $\begin{array}{l}0.004 \\
(0.12)\end{array}$ & - & - \\
\hline Governance Index $x_{[t-1]}$ & - & - & $\begin{array}{c}-0.036 \\
(1.06)\end{array}$ & $\begin{array}{c}-0.025 \\
(0.74)\end{array}$ \\
\hline Staggered Board $_{[t-1]} *$ CEO Turnover $[t-1]$ & - & - & - & - \\
\hline $\begin{array}{l}\text { CEO-Board Chairman Duality }[t-1] \\
\text { Staggered Board } \\
\text { St-1] }\end{array}$ & $\begin{array}{l}0.004 \\
(0.60)\end{array}$ & $\begin{array}{l}0.003 \\
(0.22)\end{array}$ & - & - \\
\hline Governance Index $x_{[t-1]}$ * Staggered Board $[t-1]$ & - & - & $\begin{array}{l}0.106^{* * *} \\
(2.90)\end{array}$ & $\begin{array}{c}0.084^{* *} \\
(2.28)\end{array}$ \\
\hline Sample Period (Years) & $\begin{array}{l}1996- \\
2011 \\
\end{array}$ & - & $\begin{array}{l}1978- \\
2011 \\
\end{array}$ & - \\
\hline$N$ & 19,743 & 14,376 & 10,841 & 9,930 \\
\hline Adjusted R-2 & 0.71 & 0.72 & 0.75 & 0.76 \\
\hline Clustering of Standard Errors & Firm & Firm & Firm & Firm \\
\hline Firm Fixed Effect & Yes & Yes & Yes & Yes \\
\hline
\end{tabular}




\section{APPENDix TABle A.6: Firm Value AND STAgGERED BoARds}

\section{INTERACTIONS OF STAGGERED BOARD WITH EXECUTIVE COMPENSATION}

In Appendix Table A.6 we present time-series analysis as in Table 4 that includes interactions with variables that capture executive compensation. We include the following control variables. In columns(1), (3) and (5)

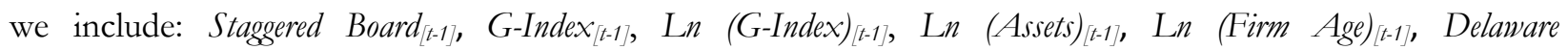

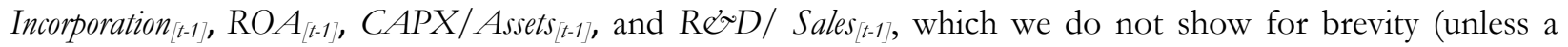
variable is being interacted with Staggered Board $[-1]]$. In columns(2), (4) and (6) we include: Staggered Board $[-1], G$ -

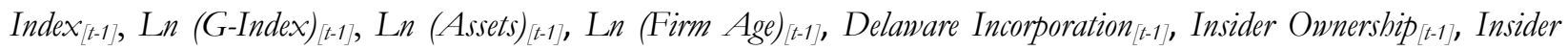
Ownership ${ }_{[t-1]}, R O A_{[t-1]}, C A P X / A_{\text {ssets }[t-1]}$, and R\&D/ Sales $[[t]]$, which we do not show for brevity (unless a variable is being interacted with Staggered Board $[t-1]$. The interacted variables include the following: CEO Delta $[t-$ 1], CEO Vega $[t-1]$, and CEO Total Compensation $[t-1]$. The sample period is 1978-2011. Individual interactions vary in their availability, as noted by the observation count and year span for each estimated model. All continuous variables in the interaction terms (CEO Delta $[t-1], C E O$ Vega $_{[-1]}$ and CEO Total Compensation $\left.[t-1]\right)$ are demeaned prior to calculating their interactions with Staggered Board $[t-1]$. Estimation is using pooled panel Tobin's $Q_{[t]}$ regressions. We include (but do not show for brevity) year and firm fixed effects. All interaction and control variables are defined in Table 1. Standard errors are clustered at the firm level. T-statistics (in their absolute value) are shown in parentheses below the coefficient estimates. Statistical significance of the coefficients is indicated at the $1 \%, 5 \%$, and $10 \%$ levels by ${ }^{* *},{ }^{* *}$, and ${ }^{*}$, respectively, in two tailed tests. 
Appendix TABle A.6: Firm VALUE AND STAggered BOARDS

INTERACTIONS OF STAGGERED BOARD WITH EXECUTIVE COMPENSATION (CONTINUED)

\begin{tabular}{|c|c|c|c|c|c|c|}
\hline Variables & $(1)$ & $(2)$ & (3) & (4) & $(5)$ & $(6)$ \\
\hline Staggered Board $_{[t-1]}$ & $\begin{array}{c}0.138^{* *} \\
(2.62)\end{array}$ & $\begin{array}{c}0.135^{* *} \\
(2.56)\end{array}$ & $\begin{array}{c}0.141^{* *} \\
(2.44)\end{array}$ & $\begin{array}{c}0.132^{* *} \\
(2.33)\end{array}$ & $\begin{array}{c}0.119^{* *} \\
(2.50)\end{array}$ & $\begin{array}{c}0.112^{* *} \\
(2.37)\end{array}$ \\
\hline CEO Delta $[t-1]$ & $\begin{array}{c}0.057^{* * *} \\
(4.05)\end{array}$ & $\begin{array}{c}0.054^{* * *} \\
(3.73)\end{array}$ & - & $\begin{array}{l}- \\
-\end{array}$ & $\begin{array}{l}- \\
-\end{array}$ & - \\
\hline CEO Vega $[t-1]$ & $\begin{array}{l}- \\
-\end{array}$ & - & $\begin{array}{l}-0.09 \\
(1.51)\end{array}$ & $\begin{array}{l}-0.09 \\
(1.49)\end{array}$ & $\begin{array}{l}- \\
-\end{array}$ & $\begin{array}{l}- \\
-\end{array}$ \\
\hline CEO Total Compensation $[t-1]$ & $\begin{array}{l}- \\
-\end{array}$ & $\begin{array}{l}- \\
-\end{array}$ & - & - & $\begin{array}{c}0.087^{* * *} \\
(4.22)\end{array}$ & $\begin{array}{c}0.081^{* * *} \\
(3.72)\end{array}$ \\
\hline CEO Delta $[t-1] *$ Staggered Board $_{[t-1]}$ & $\begin{array}{l}0.009 \\
(0.52)\end{array}$ & $\begin{array}{l}0.008 \\
(0.51)\end{array}$ & $\begin{array}{l}- \\
-\end{array}$ & $\begin{array}{l}- \\
-\end{array}$ & - & - \\
\hline CEO Vega $[t-1] *$ Staggered Board ${ }_{[t-1]}$ & $\begin{array}{l}- \\
-\end{array}$ & $\begin{array}{l}- \\
-\end{array}$ & $\begin{array}{c}0.221^{* * *} \\
(2.89)\end{array}$ & $\begin{array}{c}0.227^{* * *} \\
(2.88)\end{array}$ & $\begin{array}{l}- \\
-\end{array}$ & $\begin{array}{l}- \\
-\end{array}$ \\
\hline CEO Total Compensation $[t-1]$ * Staggered Board $[t-1]$ & $\begin{array}{l}- \\
- \\
\end{array}$ & - & $\begin{array}{l}- \\
- \\
\end{array}$ & $\begin{array}{l}- \\
- \\
\end{array}$ & $\begin{array}{c}0.066^{* *} \\
(2.4) \\
\end{array}$ & $\begin{array}{c}0.073^{* *} \\
(2.57)\end{array}$ \\
\hline Sample Period (Years) & $1992-2010$ & - & $1992-2010$ & - & $1992-2011$ & - \\
\hline $\begin{array}{l}N \\
\text { Adjusted R-2 } \\
\text { Clustering of Standard Errors } \\
\text { Firm Fixed Effects }\end{array}$ & $\begin{array}{c}11,466 \\
0.75 \\
\text { Firm } \\
\text { Yes }\end{array}$ & $\begin{array}{l}10,593 \\
0.75 \\
\text { Firm } \\
\text { Yes }\end{array}$ & $\begin{array}{c}10,439 \\
0.74 \\
\text { Firm } \\
\text { Yes }\end{array}$ & $\begin{array}{c}9,664 \\
0.74 \\
\text { Firm } \\
\text { Yes }\end{array}$ & $\begin{array}{c}11,582 \\
0.74 \\
\text { Firm } \\
\text { Yes }\end{array}$ & $\begin{array}{c}10,732 \\
0.75 \\
\text { Firm } \\
\text { Yes }\end{array}$ \\
\hline
\end{tabular}

